Wojciech Bogusławski

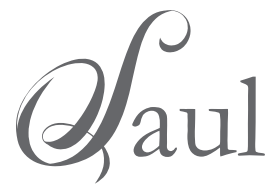





\title{
Wojciech Bogusławski
}

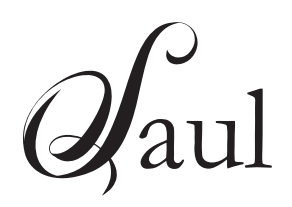

Tom z serii

Prace Katedry Edytorstwa Wydziału Filologicznego UŁ

\author{
WSTĘP \\ Liwia Purgał
}

OPRACOWANIE TEKSTÓW

Liwia Purgał

Barbara Wolska

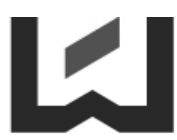

WYDAWNICTWO

UNIWERSYTETU

KÓDZKIEGO

LÓDŹ 2014 
Redaktor naukowy

prof. dr hab. Barbara Wolska

Purgat Liwia

Recenzent naukowy

prof. dr hab. Krystyna Maksimowicz.

Ilustracja na okładce

Barbara Wojtal

Skład

Liwia Purgat

Korekta

Anna Wolska

(C) Copyright by Uniwersytet Lódzki, Łódź 2014

Wydrukowano z gotowych materiałów dostarczonych do Wydawnictwa UŁ przez Katedrę Edytorstwa UŁ

Wydane przez Wydawnictwo Uniwersytetu Lódzkiego

Wydanie I. W.06881.15.0.K

Ark. wyd. 7; ark. druk. 9

ISBN 978-83-7969-628-4 (wersja papierowa)

ISBN 978-83-7969-629-1 (wersja online)

Wydawnictwo Uniwersytetu Łódzkiego

90-131 Łódź, ul. Lindleya 8

www.wydawnictwo.uni.lodz.pl

e-mail: ksiegarnia@uni.lodz.pl

tel. (42) 66558 63, faks (42) 6655862 


\section{WSTĘP}

Niniejszy tomik, szósty z serii Prace Katedry Edytorstwa Wydziału Filologicznego Uniwersytetu Lódzkiego, zawiera tekst dramatyczny oświeconego twórcy, Wojciecha Bogusławskiego. Pisarz znany jest przede wszystkim jako autor dzieł takich jak Cud mniemany, czyli Krakowiacy i Górale, Henryk VI na towach, ale i jako tłumacz, czy też dyrektor Teatru Narodowego. Motywacją do wydania niniejszej publikacji stał się fakt nieopublikowania, jak dotąd, wielu sztuk z dwunastotomowej pozycji Dijieł dramatycznych ${ }^{1}$.

Następująca edycja jest przeto krytycznym wydaniem sztuki wystawionej w 1809 roku w Warszawie. Podstawą wydania został pierwodruk Saula, opublikowany przez Bogusławskiego w wyżej wymienionych Driełach dramatycznych, wydanych w 1823 roku. Przygotowując edycję, opierano się o zamieszczone w Cyfrowej Bibliotece Narodowej Polona fotografie stronic dramatu oraz stronic tworzacych ramę wydawniczą utworu². Kolejność przedstawianych tekstów została zachowana zgodnie z oryginalnym założeniem Wojciecha Bogusławskiego.

We wprowadzeniu do lektury zwrócono uwage nie tylko na biogram Vittorio Alfieriego. Na sztukę Saul spojrzano również od strony fabularnejprezentując losy tytułowej postaci w ujęciu zarówno biblijnym, jak i literackim. Podjęto się również analizy i interpretacji dzieła dramatycznego. Analiza kreacji psychologicznejgłównegobohatera tragedii Saulstała sięmotywacjądokładnego przebadania biblijnego przekazu, dotyczącego nie tylko dziejów króla, ale i historii starożytnego Izraela za czasów jego panowania. Aby uzyskać jak najpełniejszą wiedzę w tym zakresie, oparto się na wydaniu Biblii

${ }^{1}$ W. Bogusławski, Drieła dramatyczne, t. 1-3, Warszawa 1820; t. 4-6, Warszawa 1821; t. 7-12, Warszawa 1823.

${ }^{2}$ Tekst został tu zdigitalizowany na podstawie autografu znajdującego się w Bibliotece Narodowej w Warszawie, sygn. II 64.709 A. 
Jerozolimskiej ${ }^{3}$, wyposażonej w obszerne objaśnienia o charakterze naukowym. Dzięki temu zgromadzone tu wiadomości mogą okazać się pomocne nie tylko dla filologów, ale i biblistów, teologów oraz pasjonatów starożytnej historii Izraela. Podczas pracy warsztatowej nad Saulem odnaleziono skrypt teatralny tejże sztuki, pióra Karola Łopuszańskiego z 1815 roku$^{4}$. Jest to odkrycie istotne, ponieważ do tej pory badacze za jedyny przekaz Saula uznawali dzieło Wojciecha Bogusławskiego, a rękopis uważali za zaginiony. Zważając na fakt, iż na skrypcie znalazły się kreślenia nieznanego cenzora, dokonano licznych poszukiwań informacji na temat tej osoby. Porównano również obydwa przekazy oraz poruszono zagadnienie teatru i cenzury we Lwowie w XIX w.

Tekst dramatu opublikowano według zasad opracowywania tekstów oświeceniowych, przyjętych w Katedrze Edytorstwa Uniwersytetu Lódzkiego w ramach seminariów magisterskich i doktoranckich prowadzonych przez profesor Barbarę Wolska. Od kilku lat w Katedrze realizowany jest projekt badawczy, zmierzający do wydania najbardziej wartościowych sztuk Bogusławskiego, reprezentujących różne gatunki literackie (tragedia, opera, komedia, komedioopera). Dotąd opracowano ok. dziesięciu dzieł „ojca polskiego teatru" m.in. Amazonki, Kobieta dotraymujaca selkretu, Lanassa, caylli wdowa Malabaru, Mitość i tajemnica, Sžkoła kobiet, Figiel za figiel, Czrtowiek, jakich mato.

Edytowanie sztuk Bogusławskiego zamieszczonych w Driełach dramatycznych dostarczyło zarówno Magistrantom, jak i Promotorowi ich prac satysfakcji, płynącej z odkrywania coraz to nowych obszarów tematycznych $\mathrm{i}$ interesujacych realizacji gatunkowych, zapisanych w obszernym dorobku tego wspaniałego dramatopisarza.

Chciałybyśmy, by niniejszy tomik dostarczył dobrej lektury, a także stał się pomocą dydaktyczną. Mamy nadzieję, że wzbogaci on wiedzę o twórczości Wojciecha Bogusławskiego - zarówno jako autora, jak i edytora scenicznych utworów.

Barbara Wolska

Liwia Purgat

${ }^{3}$ Biblia Jerozolimska, wyd. Pallotinum, Warszawa 2006.

${ }^{4}$ K. Lopuszański, Saul, Śląska Biblioteka Cyfrowa, rkps, sygn. 705. 


\section{VITTORIO ALFIERI — DROGA ŻYCIA I TWÓRCZOŚCI AUTORA ORYGINAŁU TRAGEDII BOGUSŁAWSKIEGO}

Przystępując do analizy sposobu adaptacji tragedii Saul Vittorio Alfieriego dokonanej przez Wojciecha Bogusławskiego, warto przyjrzeć się uprzednio samej sylwetce włoskiego twórcy, jego poglądom, aspiracjom i osiagnięciom twórczym. Równocześnie badania te w pewien sposób uzasadnią motywację Bogusławskiego do zaczerpnięcia tematu sztuki właśnie od Alfieriego.

Vittorio Alfieri przyszedł na świat 16 I 1749 roku w Asti (północne Włochy) w zamożnej, arystokratycznej rodzinie. Już od najmłodszych lat rozwijał się w klimacie niepokoju, melancholii i poczuciu niemożności istnienia wobec otaczającej go rzeczywistości. Tuż po urodzeniu osierocony przez ojca, w dzieciństwie skryty i wyalienowany, pozostający w konflikcie z najbliższą rodzina; popadając niejednokrotnie w choroby, kierowany kontestacją i skłóceniem z samym sobą, zdecydował się popełnić samobójstwo, które na szczęście nie doszło do skutku. Przyjaciela i powiernika odnalazł w kuzynie zmarłego ojca, Benedetcie Alfierim, szczególnie w latach 1758-1766, kiedy to uczęszczał do wojskowej Akademii Królewskiej w Turynie. Korzyścią wynikającą z tego typu edukacji stało się włączenie go do armii, gdzie spędził osiem lat, zyskując rangę chorążego. Czas ten poświęcił rozlicznym podróżom, nie tylko po Włoszech, ale i niemalże po całej Europie: Hiszpanii, Francji, Anglii, Austrii, Holandii, Skandynawii, Rosji. Pokaźny majątek zapewnił mu możliwość rezydowania na wielu dworach, z czego jednak niechętnie korzystał. Ulegał za to bezwiednie urokowi pięknych kobiet, przeżywając pierwsze nieszczęśliwe miłości. Ukojenie po bolesnych rozstaniach przynosił mu teatr, gdzie spędzał każdą wolną chwilę. Słowem: niczym dandys wiódł życie lekkie i próżniacze, spędzane na trwonieniu pieniędzy, życie doprowadzające go wręcz do stagnacji i marazmu. 
Rok 1775 przyniósł wielki zwrot i wewnętrzną przemianę w życiu Alfieriego, którą on sam nazwał „nawróceniem na literaturę”: „Gdybym nie odkrył w sobie płonącego źródła sił twórczych, musiałbym, mając niespełna trzydzieści lat, zwariować lub rzucić się w nurty wody ${ }^{1 "}$. Odnajdując swoje powołanie, zamieszkał w Turynie i oddał się pracy twórczej. Wiele czytał, zapoznawał się z dziełami klasyków renesansu i filozofów antyku, odwiedzał również wielokrotnie Toskanię, uznawana za kolebkę włoskiego języka literackiego. Zaczytywał się w dziełach wielkich twórców w samotności i odosobnieniu u stóp wzgórz Monginevro. W 1777 roku podjął decyzję o zamieszkaniu we Florencji, przekazując uprzednio majątek siostrze, w zamian za dożywotnią rentę. To tutaj poznał miłość swojego życia, kobietę wówczas pozostającą od pięciu lat w związku małżeńskim: hrabinę Louisę d' Albany, żonę Karola Edwarda Stuarta, pretendenta do tronu angielskiego. Alfieri, zauroczony łagodnościa, inteligencją i urodą Louisy, podążał w ślad za nią, uczestnicząc w jej podróżach do Toskanii, Rzymu, Alzacji i Paryża. Po trzech latach hrabina zdecydowała się na rozwód, by w 1785 roku zamieszkać we Francji, a później Florencji u boku ukochanego, pozostając wierną towarzyszką życia do końca jego dni.

Postanowienie o opuszczeniu Turynu i przeprowadzce do Florencji zainicjowało wielką, twórczą przygodę Alfieriego. Wcześniej dokonywał przekładów Ajschylosa, Sofoklesa i Eurypidesa; na przełomie lat 1774/1775 rozpoczął pracę nad tragedią Cleopatra, również w 1775 opracował wstępnie dzieła Filip i Polinik. Dopiero po scenicznym sukcesie napisanej przez niego Antigony, podjął się w Sienie druku pierwszego wydania swoich tragedii w 1783 roku. Został uczestnikiem Akademii Arkadyjskiej, wtedy tė̇ wyruszył w podróż do grobów wielkich twórców: Dantego, Petrarki i Ariosta, wędrował również z ukochaną do Alzacji i Paryża. W roku 1801 stanowczo odmówił uczestnictwa we współtworzeniu i realizowaniu programu Turyńskiej Akademii Nauk. Ostatnie lata życia spędził na pracy nad komediami i ostatnim, piątym działem autobiografii, La Vita. W 1803 roku zachorował nagle i po kilku dniach zmarł

${ }^{1}$ V. Alfieri, La Vita scritta da esso, [w:] Opere scelte di Vittorio Alfieri, Paryż 1847, s. 83. Cyt. za: Z. Wołoszyńska, Wojciech Bogustawski wobec wzorón dramaturgii zachodnioeuropejskiej, [w:] Antynomie Ośniecenia. Tom specjalny w 200 rocznice Konstytuciz 3 Maja, Wrocław 1991, s. 233. 
8 października tegoż roku. Pochowano go we franciszkańskiej świątyni Santa Croce, obok innych wybitnych postaci, takich jak Michał Anioł, Dante Alighieri, Galileusz, Machiavelli. Louisą zaopiekował się malarz François-Xavier Fabre, przyjaciel zmarłego.

Na twórczość poetycką Vittorio Alfieriego składają się Satyry (1797) pisane tercyną oraz inspirowane Petrarką Rymy (1798). Po śmierci twórcy wydano siedemnaście satyr z lat 1792-1797 (1806), a także Misogallo (Wróg Francurón) —zbiór sonetów, epigramatów i fragmentów prozy o charakterze antyfrancuskim (1814). Autobiografia La Vita, stylizowana na wzór WyznańJana Jakuba Rousseau, wydana w edycji pośmiertnej przez hrabinę Albany w 1804 roku, uważana jest za jedno z najważniejszych dzieł Alfieriego. Składa się z czterech części: Pueriz̨ia (D stwo), Adolescenza (Wiek dojrzewania), Giovinezza (Mtodość), Virilità (Wiek mesker) oraz ostatniej, Starość, niedokończonej z powodu przedwczesnej śmierci twórcy.

Rzeczywistą popularność zyskał przede wszystkim dzięki tragediom tworzonym w przeciagu lat 1774-1789, które w całej okazałości uwidoczniły jego talent. Pisane jedenastozgłoskowcem, umiejscowione najczęściej w fabularnej przestrzeni antyku i prezentujące konflikt $z$ despotycznym władca, dzięki osobliwej formie i tematyce nawołującej do walki z tyrania przyniosły mu rozgłos i renomę. Spośród 19 tragedii wymienić należy przede wszystkim: Virginie, Filippa, Timoleona, Sofonisbe, Merope, Ottavie i najważniejsze: Mirre, Spisek Paccich, Marie Stuart. Zofia Wołoszyńska podkreśla szczególną wartość tragedii Saul. Badaczka osiemnastowiecznego teatru pisze:

Odrębna pozycję zajmuje powstały w latach 1782-

1784 biblijny Saul. (...) Jego [Alfieriego] tragedie

były czytane i wystawiane w rzymskich salonach; (...) w kwietniu 1783 recytował Saula podczas uroczystego przyjmowania go do Arkadii; papież Pius VI wyraził życzenie poznania podziwianego autora i przyjął go na specjalnej audiencji².

Dzieła tragiczne Alfieriego wydane zostały w dwóch edycjach: sieneńskiej, w której znalazło się dziesięć tekstów (1783-1785) oraz paryskiej, zawierającej wszystkie tragedie (1787-1789).

${ }^{2}$ Z. Wołoszyńska, op. cit., s. 233. 
W poglądach i zainteresowaniach ideologiczno-filozoficznych był Vittorio Alfieri postacia niezwykła, łączył bowiem wierne oddanie duchowi epoki z buntem przeciw niemu; wiedza i umysł wrosłe w epokę oświeceniową, nieuchronnie przekierowywały się w jego poglądach i dorobku artystycznym ku ideom romantycznym. Nie interesowały go odkrycia naukowe i wynalazki ówczesnych mu eksploratorów, przemiany ekonomiczne, rozwój handlu, przemysłu i techniki. Za postępowanie zbędne i nieużyteczne uznawał propagandę kultury i jej powszechną dostępność. Za to apoteozą obdarzał jednostki wybitne, zdolne do przeciwstawiania się światu, potrafiące go wzbogacić i oświecić, nawet gdyby łamały przy tym obowiązujące prawa i zasady moralne. Pragnął i szukał wolności społecznej, ufając w możliwość ciąłego kształtowania i doskonalenia człowieka. Gloryfikował swój naród poprzez ksenofobiczne nastawienie do innych nacji, szczególnie francuskiej. Uważał, że pisarz i władca powinni stanowić dwa niezależne od siebie ogniwa; twórca, uzależniony od mecenatu panującego, nie mógłby wypełniać swej misji w zupełnej autonomii z jednoczesną czystością intencji i świadomościa posłannictwa: nauki umiłowania wolności. Mimo że czuł się arystokrata, krytykował tę grupę społeczna, co nie oznacza, że aprobowal inne — gardził plebsem, nie popierał mieszczańskiej demokracji, potępiał władzę despotyczną. Natalia Sapegno zauważa, iż „całe rewolucyjne dążenie Alfieriego znajduje wyraz nie rozumowy lecz obrazowy, prowadzi do afirmacji poezji, a nie filozofii"”.

Początkowo wierny sensualizmowi i materializmowi, z czasem Alfieri wyklarował w sobie stanowisko silnie antydespotyczne, czemu dał wyraz szczególnie w pismach politycznych Della tirannide (O tyranii) i Del principe e delle lettere (O ksieciu i literaturze). Kreuje tu obraz tyrana jako podejrzliwego i okrutnego władcę-uzurpatora, łamiącego prawo i ciemiężącego swój naród. Takich panujących dostrzegał niemalże w każdym kraju: Fryderyka II (Prusy), Marię Teresę (Austria), Katarzynę II (Rosja), Ludwika XV (Francja). W jego opinii rządzący za wzór obierają sobie religię monoteistyczną i Boga — prekursora politycznego despoty. Tyranią była więc dla niego wszelka władza ${ }^{4}$, zarówno

${ }^{3}$ N. Sapegno, Historia literatury włoskiej w zarysie. Podrecznik, Warszawa 1969, s. 439.

${ }^{4}$ Zob. J. Heinstein, Historia literatury włoskiej. Zarys, Wrocław 1979, s. 144. 
monarchia absolutna, jak i republika oligarchiczna. Uwżał, że przywrócenie słusznego ustroju byłoby możliwe dzięki zrywom narodowym lub tyranobójstwu. W nurcie determinizmu historycznego, związanego z przekonaniem o cykliczności historii, wierzył w powstanie włoskiej, zjednoczonej republiki. Jak podkreślaja Jadwiga Miszalska i Józef Heistein, refleksje Alfieriego nie stanowią szczególnej innowacji na tle epoki; ponadto nie są one na tyle precyzyjnie wykrystalizowane, by mogły stanowić konstruktywny program ${ }^{5}$.

O ile zainteresowanie myślą polityczną nie stanowiło dla Alfieriego najistotniejszej materii, zupełnie inaczej rzecz się miała w przypadku jego stanowiska wobec aktu twórczego ${ }^{6}$. Zdaniem Alfieriego, literatura i kontakt z nią umożliwiają pisarzowi ujawnienie własnej indywidualności tam, gdzie reprezentuje on wyłącznie własne idee. Za najsłuszniejszą formę do realizacji własnych postulatów obrał tragedię. To tu „objawił swój najsilniejszy i najbardziej oryginalny temperament poetycki, w tym wysiłku, jakiego potrafił i zechciał dokonać, by ujarzmić owo płynne i oporne tworzywo, by przekształcić je w obrazy wyraziste i plastyczne, nagiąć do norm rodzaju i języka ściśle klasycznego 7”.

Inspiracji twórczych poszukiwał Alfieri w historii, Biblii i mitologii, podpierając się autorytetami starożytnych, zwłaszcza zaś Plutarcha i Arystotelesa. Decydując się na tematy znane, wydobywał z nich drugorzędne sytuacje i eksponując je, przedstawiał znajome treści w nowatorski, oryginalny sposób. Alfieri starał się tworzyć sztuki z jak najmniejszą liczbą postaci i wątków, pozbawiając je zbędnych dygresji i wtrąceń, co sam nazywał „ograniczeniem wynalezienia" "Język, którym się posługiwał, odbiegał od tendencji neoklasycystycznych propagujących uczuciowość sentymentalizmu (kreował tym samym odmienny, nowy styl wypowiedzi). Stanowi on jeden z najistotniejszych komponentów dzieł, o ile sam w sobie nie jest ich meritum. Alfieri pozbawiał teksty

${ }^{5}$ Por. ibidem, s. 145; J. Miszalska, Historia teatru i dramatu wtoskiego, t. 1, Kraków 2008, s. 384.

${ }^{6}$ Swoje rozważania nad gatunkiem dramatycznym sformułował Alfieri w odpowiedziach na listy Ranieriego de' Calzabigi: Odpowiedź, Autora na list Ranieriego de' Calzabigi (1783), Sad o wtoskiej sz̨uce komicznej (1785), Sad o tragediach (1788), Zbiór listóm.

${ }^{7}$ N. Sapegno, op. cit., s. 448.

${ }^{8}$ Por. L. Osiński, Drieła, Warszawa 1863, s. 388. 
ozdób poetyckich, retorycznych figur, tworząc z nich konstrukcje ascetyczne, pozbawione melodyjności i płynności. Jego tragedie pisane były najczęściej jedenastozgłoskowcem, wierszem białym, zaś dialogi nierzadko przybierały postać stychomytii lub wręcz jednowyrazowych replik?

Schemat fabularny dla swoich tragedii tworzył Alfieri w oparciu o poglady polityczne. W większości wypadków bohater walczący o wolność ściera się z bezwzględnym despota; dzięki gradacji i stopniowemu natężaniu emocji konflikt nabiera na sile, doprowadzając do ostatecznego starcia, gdzie ginie przedstawiciel jednej ze stron (lub oboje). Jednostki wybitne, stające po stronie dobra, zdolne są do poświęcenia własnego życia dla idei wyższych, zwłaszcza tej najważniejszej — wolności. Jadwiga Miszalska zwraca uwagę, iż „końcowa katastrofa nigdy nie stanowi przedmiotu opowiadania, lecz dzieje się na oczach widzów: bohaterowie umierają na scenie. Istotne jest również, aby zakończenie wprowadziło widza w stan zdumienia stanowiącego rodzaj suspensu, dlatego często sytuacja pozostawała otwarta, co pozwalało na kontynuowanie tematu w następnym dramacie i łączenie niektórych utworów w dyptyki ${ }^{10}$ ".

Autor ten dokonuje mistrzowskiej kreacji psychologicznej postaci, doskonale obdarza je pełna paletą uczuć, eksperymentując przy tym możliwość reakcji człowieka w związku z umiejscowieniem go w sytuacji zawiłej, najczęściej nieposiadającej rozwiązania. Bohaterowie, świadomi swojego niechybnego upadku lub spełnienia ciążącego nad nimi fatum, plączą się w sieci przeżyć i toczą wewnętrzną walkę ze sobą i otaczającym światem. Redukcja postaci wyłącznie do tych najistotniejszych umożliwiła Alfieriemu wypełnianie tekstów dramatycznych licznymi monologami wewnętrznymi. Nie przekraczają one więcej niż 30 wersów i zawsze uwarunkowane są psychologicznie oraz sytuacyjnie.

Alfieri szczególny nacisk kładzie na precyzyjne ukształtowanie struktury tekstu dramatycznego. Rezygnuje z przedakcji i rozbudowanych didaskaliów; widz tudzież czytelnik w sytuację wprowadzony zostaje poprzez same dialogi. Pierwszy akt, stosunkowo najkrótszy wobec pozostałych, miał na celu wprowadzenie w okoliczności zdarzeń, kolejne trzy zawierały właściwe rozegranie

${ }^{9}$ Zob. Z. Wołoszyńska, op. cit., s. 234.

${ }^{10} \mathrm{~J}$. Miszalska, op. cit., s. 385. 
akcji, w końcu ostatni, podobnie jak pierwszy, charakteryzował się zwięzłością i precyzją komunikatu. Główny bohater ujawniał się przeważnie dopiero w akcie drugim. Poprzez stosowanie elipsy, wtrąceń oraz inwersji, pisarz nadawał wypowiedziom niespotykany jak na ówczesną epokę kształt, pogłębiany brakiem wewnętrznych rymów i unikaniem melodyjności.

Alfieri kładł nacisk na zasady gry aktorskiej i problemy związane z inscenizacja. Stąd, zanim gotowe dzieło ujrzało światło dzienne, uprzednio oddawane było kilkunastu recenzentom, nazywanym przez niego semi-publicco (pół-publicznościa). Autor dramatów krytykował sztuczna, zbyt uschematyzowaną i wyuczoną grę aktorską ${ }^{11}$. Sufler był osobą zbędna; do zadań aktorów należało gruntowne przyswojenie swoich ról, by później posługiwali się nimi efektownie, sprawnie i przede wszystkim skutecznie. Alfieri unikał przesadnej, wystudiowanej gestykulacji, preferował styl naturalny, lecz i ten momentami uznawany był przez krytyków za niezbyt stosowny ${ }^{12}$. Brakowało mu dużej przestrzeni scenicznej, koordynacji i uporządkowania w grze i doborze sztuk, marzył zatem o utworzeniu teatru narodowego, w którym stały dopływ finansowy zapewniłby sprawną organizację instytucji. Poeta sam brał chętnie udział w przedstawieniach; publiczność ujrzeć mogła go w sztukach takich jak chociażby: Antigona, Filippo, Saul. Kiedy aktorzy występowali w innym mieście i nie miał możliwości współuczestnictwa w organizacji przedstawienia, posyłał wskazówki reżyserskie listownie.

W akcie twórczym zwracał uwagę na wykoncypowane przez siebie trzy etapy konstruowania tekstu dramatycznego. Należały do nich: koncepcja tematu, zarys struktury akcji, zapis i szata rytmiczna oraz scenariusz i sty $1^{13}$. Do trzeciej grupy włączyć należy siłę emocjonalną, nadająca jego utworom swoista, oryginalną wartość. Owe zabiegi potwierdzaja dbałość o szczegóły i staranność

${ }^{11}$ Założenia poprawnej gry aktorskiej zawarł Alfieri w rozprawie Parere sull' arte comica in Italia (Sad o wtoskiej sztuce komicznej).

${ }^{12}$ Zob. J. Miszalska, op. cit., s. 387.

${ }^{13}$ Sam etap pisania również składał się z dwóch etapów. Pierwszy z nich, stesura, polegał na rozpisaniu tekstu na dialogi proza, w kolejnym — versificitazione — zamieniał prozę na wiersz. Zob. ibidem. 
o formę ${ }^{14}$, które wyklarowały u Alfieriego styl niekonwencjonalny, stanowiący wzorzec dla późniejszych twórców.

Już za życia zyskał uznanie krytyków i pisarzy. Ranieri de’ Calzabigi po lekturze sztuk Alfieriego, wielokrotnie wystawiał im opinie pozytywne, doceniając odstępstwo od obowiązujących tendencji i indywidualny, niepowtarzalny wkład twórczy. Podobnie oceniali jego dokonania Jean Charles de Sismondi czy Melchiore Cesarotti, choć ten ostatni często posyłał mu wskazówki w trosce o doskonalenie formy i uszlachetnienie kunsztu literackiego twórcy.

W Polsce przed upowszechnieniem sztuk Alfieriego przez Wojciecha Bogusławskiego ślad zainteresowania włoskim artystą jest niemalże znikomy. Pierwsze wzmianki o Alfierim zawierają się w rozprawie Grzegorza Piramowicza, odnoszącej się krytycznie do „Pamiętnika Historyczno-Politycznego”, czasopisma redagowanego przez Piotra Świtkowskiego ${ }^{15}$. Julian Ursyn Niemcewicz w 1793 roku wyjechał do Włoch, aby móc spotkać się z Alfierim, co obszernie opisał późnej w „Dzienniku Wileńskim” (tu także 13 lat później ukazał się artykuł: Wiadomość o życiu i pismach hrabiego Wiktora Alfieri da Asti). W 1805 roku Franciszek Wężyk zainspirowany twórczością Alfieriego napisał tragedię Don Carlos $^{16}$. Dopiero warszawska premiera Saula, tragedii zaadaptowanej przez Wojciecha Bogusławskiego w 1809 roku, rozbudziła powszechne zainteresowanie Alfierim. W 1815 roku Saula zagrano ponownie we Lwowie. Tymczasem na scenie Teatru Narodowego ukazywały się kolejne sztuki Alfieriego: Filip II (1816, tłum. L. Kamiński), Wirginia (1818, tłum. Alojzy Feliński), Agamemnon (1823, tłum. anonimowy), Antygona (1825, tłum. Jan Kruszyński). O trudnościach związanych $z$ adaptacją włoskich tragedii na grunt polski pisał Herkules Chyliński:

${ }^{14}$ Tworzenie poszczególnych dzieł zabierało mu od kilku miesięcy do nawet 2-3 lat.

${ }^{15}$ Mowa tu o publikacji Piramowicza: Przestrogi dla caytajacych pisma historyczno-polityczne, jako to pamiętniki, džienniki, wojaže, geografie i tym podobne. Zob. Z. Wołoszyńska, op. cit., s. 236.

${ }^{16}$ Franciszek Wężyk na zamówienie Towarzystwa Przyjaciół Nauk napisał traktat O poezji dramatycznej, w którym gloryfikował i oceniał wysoko twórczość Alfieriego, argumentując swoje stanowisko licznymi wywodami. Jednak eksperci Towarzystwa odrzucili założenia młodego badacza; zainteresowali się przekładami Alfieriego dopiero po premierze Saula. 
Kto czytał i zrozumiał ducha poezji Alfieriego w oryginalne, ten czuje nieprzełamane trudności ich wykładu ${ }^{17}$.

Największa popularność zyskał Alfieri w Polsce w latach dwudziestych XIX wieku, kiedy jego nazwisko zestawiano obok wybitnych twórców takich jak Voltaire czy Schiller ${ }^{18}$. Kolejne dziesięciolecie zamyka okres fascynacji włoskim twórca; w 1834 roku Karol Czarnocki dokonal jeszcze trzech przekładów: Antygony, Filipa II i Polinike. Można powiedzieć, że Alfieri „zszedł” ze sceny, by ustapić miejsca kolejnemu artyście — Schillerowi ${ }^{19}$.

Cóż zatem zainspirowało Wojciecha Bogusławskiego, aby podjać się tłumaczenia i wystawienia na scenie sztuki niepopularnego już wówczas autora? Być może zadecydował o tym szczególnie silny ładunek emocjonalny przekazu, idealne kreacje psychologiczne bohaterów oraz nawiązania do systemu politycznego i władzy, jakie niosły dzieła włoskiego artysty, a co za tym idzie — trudności przekładu i wystawienia na scenie ${ }^{20}$. Bogusławski, poszukując dzieł do adaptacji na grunt polski, zawsze decydował się na te, które początkowo stawiały przed nim rozległe wymagania, ale w ostatecznym rozrachunku przynosiły powodzenie i renomę.

Anonimowy recenzent „Gazety Korespondenta Warszawskiego”, oceniając premierę przedstawienia Saula, słusznie ukazał (i docenił) intencje wysiłku Bogusławskiego:

Kto go widział w roli Leara, i w tej go sobie — nie widziawszy - wystawić potrafi, z tą różnica iż rola Saula więcej natężeń wymaga, więcej pracy grającego, więcej wzruszenia $(. .$.$) kosztowała widza { }^{21}$.

${ }^{17}$ Cyt. za W. Pusz, Herkules Chylinskei - „poeta tygodnikowy” z kregu mtodych pisaray przedromantycznej Warszany, [w:] idem, Miedsy Krasickim a Stowackim. Studia, eseje, opinie, Kraków 1992, s. 43.

${ }^{18}$ Zob. D. Ratajczakowa, $W$ krysztale i plomieniu. Studia i szkice o dramacie i teatrze, t. 2, Wrocław 2006, s. 388.

${ }^{19}$ Ibidem, s. 388.

${ }^{20}$ Z. Wołoszyńska zauważa, że ze względu na trudności związane z przekładem i adaptacja, tragedie Alfieriego poza Włochami nie zyskały w żadnym innym kraju nadzwyczajnego powodzenia. Zob. Z. Wołoszyńska, op. cit., s. 235.

${ }^{21}$ Cyt. za: ibidem, s. 240. 



\section{TEATR NARODOWY NA WYGNANIU}

Po dwukrotnych próbach zaborców, trzeci rozbiór Polski w 1795 roku doprowadził do ostatecznego upadku Rzeczypospolitej. Liczne instytucje popadły wówczas w dezintegrację lub spotkał je całkowity rozpad, tymczasem teatr, mimo przeciwności i utrudnień, nie rozproszył się ani na chwilę.

Cztery teatry polskie cieszyły się największą stabilizacja, a zaliczyć można do nich ośrodki: lwowski, wileński, warszawski i krakowski. W dniu ostatniego starcia zbrojnego insurekcji kościuszkowskiej (a zarazem ostatniej bitwy Rzeczypospolitej Obojga Narodów), to jest 4 listopada 1794 roku, Wojciech Bogusławski, ówczesny dyrektor Teatru Narodowego zbiegł z Warszawy. Uratował przy tym część garderoby, rekwizytów i biblioteki teatralnej, ukrywając je w Zdanowicach pod Jędrzejowem. Wybitny dramatopisarz, kierownik i aktor schronienie odnalazł we Lwowie, gdzie dostał się już przed końcem roku. Jednak, jak wynika z jego prywatnej korespondencji, nie planował rezydować tam zbyt długo:

Wyglądam tylko momentu wymknięcia się z tej jamy pożerającej krew naszą (...). Wszystko mi tu pomyślnie sprzyja, bo i aktorowie jego [Bulli] z głodu pouciekali, a i Gubernium pozwala mi na to (...) Zaraz po pierwszym będę się starał wyjechać i tak około siódmego albo ósmego maja przyjeżdżam na kapustę do Biały ${ }^{1}$.

Cóż zatem ujrzał i zastał we Lwowie Wojciech Bogusławski?

Zaczać trzeba od wiadomości fundamentalnych. Ukształtowanie stabilnego teatru polskiego we Lwowie przypada na 1809 rok. Przed rokiem 1772 nie funkcjonował tu raczej żaden profesjonalny teatr, a po pierwszym rozbiorze jego powstanie wydawało się mało prawdopodobne. Gubernator Galicji

${ }^{1}$ Rkps Bogusławskiego przechowywany w zbiorach Biblioteki Narodowej w Warszawie; adresat nieznany, Lwów, dat. 25 IV 1796. 
Heinrich Auersperg, zafascynowany włoską operą buffo, a odczuwający potrzebę obcowania ze sztuka, podjął trud utworzenia i zbudowania sceny we Lwowie. Cesarz po dłuższych negocjacjach wyraził zgodę na przeznaczenie dla sceny 2000 florenów rocznie (27 IX 1777), a w 1783 roku przydzielił plac na wzniesienie budynku. Spośród licznych chętnych na objęcie stanowiska dyrektora, wybrano ostatecznie Czecha, Franciszka Henryka Bullę. Posiadał wszechstronne wykształcenie teatralne i wieloletnie doświadczenie dzięki zajmowanym stanowiskom: aktora oraz kierownika artystycznego w Pradze u Pasqale'a Bondiniego. Dzięki przywilejowi udzielonemu od cesarza, dysponował prawem rozporządzania gmachem teatralnym. Wysoko oceniano pracę Bulli, jak to czynił chociażby Feyerabend:

Niemieckie towarzystwo miało własnego dyrektora, znanego Bullę, i mogło się poszczycić aktorami, którzy by przynieśli zaszczyt każdemu nadwornemu teatrowi ${ }^{2}$.

Jednak prawdopodobnie nie miał on do końca pełnej świadomości wielu zmagań, z jakimi musiał zmierzyć się Bulla. Ze względu na liczne wydatki w postaci czynszu, podatków, kosztów utrzymania, ogrzania, oświetlenia budynku, zakupu dekoracji i kostiumów, wynagradzania aktorów, podjął decyzję o pożyczce, której nie był w stanie później spłacić.

W takich okolicznościach zastał Wojciech Bogusławski lwowski teatr. Niemcy, mając świadomość niemałych trudności ze spłaceniem długu przez Bullę, zaproponowali Bogusławskiemu podpisanie kontraktu na sześć lat. Równocześnie obawiali się dopuszczenia go do teatru wiedząc, że wraz ze swoją polską sceną może on stać się dla nich niemałym konkurentem. Oto jak Bogusławski komentuje zaistniałe wydarzenia w jednym z kolejnych listów:

Mając kilkaset dukatów długu, a żadnej nadziei zapłacenia onych, myślałem o sposobie, żeby przynajmniej nie wsadzono człowieka ad cap ram, gdy oto Bulla zniszczony i ogołocony ze wszystkich swoich aktorów, bo ich tylko czterech

${ }^{2}$ K. B. Feyerabend, Cosmopolitische Wanderungen durch Preussen, Curland, Liefland, Litthauen, Vollhynien, Podolien, Galizien und Schlesien in den Jahren 1795-1798, Germanien 17981803, t. 4, cyt. za B. Lasocka, Teatr lwowski w latach 1800-1842, Warszawa 1967, s. 16. 
zostało, przyszedł mi się sam prosić, aby się zlitować nad nim 'wziąć oba teatra na tak długo, jak sam zechcę bez żadnej opłaty (...). Niezłą mi się to wydawało rzecza, ile że i Gubernium daje mi pozwolenie zamknięcia teatru na trzy miesiące, przez co nie potrzebowałbym utrzymywać aktorów latem. (...) Wykoncypowałem sobie projekt osobliwy, wprawdzie i rzadko praktykowany na świecie, to jest projekt udania się do wielkiego pana o wspomożenie. Ten tedy już zawsze teraz Jaśnie Wielmożny Rzewuski, protekcjonalną łaską swoja, po długich ukłonach moich (...) uniżonych przyrzekł mi 500 zł na zaczęcie tej machiny pożyczyćs.

Ostatecznie około $13 \mathrm{~V}$ Bogusławski podpisał umowę na dwa lata, przyznającą mu dyrekcję sceny polskiej i niemieckiej. Czas antrepryzy we Lwowie należał do najlepszych z obopólną korzyścią — zarówno dla niego, jak i sceny teatru. Atencja ze strony publiczności i samych władz austriackich aktywizowała go do realizacji coraz to ambitniejszych zadań. To właśnie tu po raz pierwszy wystawił Hamleta (1797). Decydował się na spektakularne widowiska, przygotowując efektowne wizualizacje, jak to było choćby w przypadku Iskahara czy Amazonek. Najczęstsze nazwiska autorów, których dzieła adaptował to: Lessing, Goldoni, Soden, Kotzebue, Brühl, Ziegler. Ogromna popularnością cieszyła się opera znana tak dobrze w Polsce - Krakowiacy i górale. Wiele wystawianych sztuk wymagało oprawy muzycznej (Herminia, czyli Amazonki, Sydney i Zuma, Iskahar), którą komponował Józef Elsner, dyrektor opery. Publiczność z ogromnym entuzjazmem przyjmowała proponowany repertuar, prawie zawsze widownia była wypełniona niemalże po brzegi. W tym też czasie Bogusławski zrezygnował z nadmiernego dydaktyzmu, zastępując go imponującymi efektami inscenizacyjnymi, treściami przesyconymi politycznymi aluzjami, ale i uwolnioną od realistycznych zasad swobodą wyobraźni.

Interesujący zdaje się również wątek miłosny w historii Wojciecha Bogusławskiego. We Lwowie poznał Annę Lampel, piękną artystkę, występującą

${ }^{3}$ Rkps Bogusławskiego przechowywany w zbiorach Biblioteki Narodowej w Warszawie; adresat nieznany, Lwów, dat. 9 V 1796. 
wielokrotnie w rozmaitych sztukach, zyskująca przy tym szczególną popularność i estymę wśród innych aktorów ${ }^{4}$. Piękny głos, którym była obdarzona, umożliwiał jej śpiewy operowe zarówno w niskich altach, jak i wysokich sopranach. Niezwykły wdzięk i radosny temperament młodej kobiety urzekły niewatpliwie przybyłego z Polski dyrektora. Stali się sobie bardzo bliscy; jednak w 1797 roku na skutek problemów finansowych, Bogusławski został zmuszony do opuszczenia Lwowa. Uprzednio spłacił niewielkie sumy, oddając w zastaw kosztowności, należące do niego i Anny. Lampel wyruszyła śladami ukochanego; spotkali się w Kaliszu w 1800 roku, gdzie występował gościnnie wraz ze swoją trupa. Niestety, ich drogi nie mogły się ponownie złączyć, tego samego roku bowiem Anna zmarła.

Warto zatrzymać się jeszcze na chwilę nad osiąnnięciami zawodowym Bogusławskiego. Lwów zawdzięczał mu jeszcze jedno — wielki, letni teatr, z doskonałym wyposażeniem, ulokowany w ogrodzie Jabłonowskich. Za zgoda gubernatora Gallenberga i pokaźnym wsparciem finansowym zamożnych obywateli wybudował niezwykły amfiteatr. Resztę kosztów pokryły dochody otrzymane z wystawienia Krakowiaków i górali ${ }^{5}$ oraz niewielkich pożyczek. Sam zadecydował o lokalizacji budynku, wybrał również projektanta, architekta Maraino, który już wcześniej dopomógł mu przy renowacji teatru w Warszawie. Gmach powstał zaledwie w ciagu sześciu tygodni, już w 1796 roku. Podczas budowy sceny, dokonano zadziwiającego, ale przerażającego odkrycia:

Oto pod sceną ukazało się sklepienie, załamane w kilku miejscach, zaś przez otwory widać było sporą liczbę trumien po części już zbutwiałych, z których bielały kości, czaszki i wygladały strzępy odzieży. Szczególniejsze wrażenie wywarł na Bogusławskim widok trumienki, wy-

${ }^{4}$ M. Piotrowska, Zza uchylonej kurtyny (o s.yciu prywatnym Wojciecha Bogusławskiego), [w:] Wojciech Bogustawski in memoriam. Materialy pokonferencyjne, Gołęczewo 2007, s. 46-48.

${ }^{5}$ Bogusławski miał świadomość trudności związanych z wystawieniem tej sztuki ze względu na jej liczne, polityczne aluzje i efekt, jaki uprzednio wywołała w Polsce. Przy pomocy gubernatora Zygmunta Gallenberga dokonał rekonstrukcji wskazanych przez niego fragmentów, dzięki czemu dzieło zyskało aprobatę generalnej cenzury w Wiedniu. 
dobytej z jednego z bocznych filarów świątyni. Spoczywała w niej sześcioletnia co najwyżej dzieweczka, w białej koszulinie i z wianuszkiem rozmarynowym na główce. (...) Teraz dopiero uwierzył dyrektor opowieściom, jakie już od dłuższego czasu krażzyły wśród służby teatralnej o istniejących pod scena grobach i przestał się dziwić suflerom, którzy tylko z latarnią i nie bez strachu odważyli się schodzić do swej budki, lękając się, by po drodze nie wpadli przez jakiś otwór do lochów. Znalezione trumny wywieziono co rychlej na cmentarz $(. . .)^{6}$.

Teatr w ogrodzie od pierwszych dni otwarcia przyciagal ogromną liczbę widzów, zachwyconych wystawianymi sztukami i samym urokiem miejsca. Początkowo scena i audytorium nie posiadały pokrycia dachowego; dobudowano je w latach kolejnych. Największą ozdobę amfiteatru stanowiło proscenium z wymalowanymi na drewnie (techniką olejna) kolumnami, przedstawiającymi kolumny starożytnej świątyni.

Najwymowniejszym świadectwem szczególnej roli, jaką odgrywał w tym czasie Bogusławski we Lwowie, jest fakt, że po jego wyjeździe teatr polski popadł w ruinę, aż do momentu ustanowienia stałej sceny przez Jana Nepomucena Kamińskiego, dramatopisarza, poety i tłumacza. Ten kierował teatrem przez trzydzieści trzy lata, pełniąc nie tylko funkcję zwierzchnika, ale i kierownika artystycznego, inscenizatora artystycznego, nauczyciela i aktora. Napisał również wiele dzieł, najczęściej przerabiając je z tekstów innych autorów: Sarassina, Rauperta, Körnera, Varina. Do dzieł oryginalnych należą między innymi: Gdzie go nie posieja tam zejdzie, Kilka scen z.biura dziennikarza, Szlakmierzanki, Zabobon, csyli Krakowiacy i Górale.

${ }^{6}$ S. Schnür-Pepłowski, Bogusławski we Lwowie. Ustepp z driejón sceny polskiej 17951799, Lwów 1895, s. 16. 



\section{LOSY SAULA NA TLE DZIEJÓW IZRAELA W UJECCIU BIBLIJNYM I LITERACKIM}

Wśród wielu antycznych dzieł, w jakich zaczytywał się włoski tragediopisarz Vittorio Alfieri, znajdowała się również Biblia. Zainspirowany historią monarchy Saula, autor ten wzbogacił literaturę włoską o dzieło dramatyczne zakorzenione fabularnie w starotestamentalnej tematyce. Podobnie jak w przypadku tramelogedii ${ }^{1}$ Abel (1790) tak i tutaj za głównego bohatera obrał postać drugoplanową, opisując dzieje nie Dawida, lecz Saula. I to właśnie jego imieniem opatrzył tytuł ukończonego dzieła. Wybór bohatera zasługuje zatem na uznanie; gloryfikowany w Piśmie Świętym i wszystkich tekstach apokryficznych Dawid, król Izraela, spycha na drugi plan osobę Saula, o ile w ogóle go nie releguje. Tymczasem Saul jest postacią niezwykle barwną, a zarazem tragiczną, na której spoczywało nieuniknione fatum.

Historyczne dane na temat życia i panowania Saula zawierają się przede wszystkim w 1 Księdze Samuela. W Biblii hebrajskiej wchodziła ona w skład Ksiąg Samuela, które z kolei w Wulgacie w połączeniu z dwoma Księgami Królewskimi stanowiły Cztery Księgi Królów. Tworzenie w oparciu o dokumenty, opisy i tradycje różnego pochodzenia, doprowadziło do swoistej niejednolitości chronologicznej tekstów, występowania w nich dubletów i niekonsekwencji czasowej w układzie fabularnym. Ich autorstwo przypisuje się Samuelowi, choć w tradycji talmudycznej wymienia się również Gada i Natana.

Rozwój dziejowy Izraela, poprzedzający rządy Saula, zdeterminowały znacznie realia chronologiczne i geopolityczne. Mimo że władza miała charakter teokratyczny, panowała tu anarchia. Brak fizycznego i realnego panującego (uwa-

${ }^{1}$ tramelogedia — gatunek dramatu muzycznego pośredni między tragedią i opera, zwracający publiczność do opery i przygotowujący ich do prawdziwej tragedii. 
żano, że jedynym królem jest Bóg) wywierał bezpośredni wpływ na politykę plemion konfederacji izraelskiej. W przypadku zagrożenia ze strony sąsiadów, wybierano wojskowego dowódcę, który miał za zadanie wyłącznie poprowadzenie ludu do walki. Jednak na skutek nasilających się konfliktów, zrodziła się konieczność posiadania permanentnego władającego, na wzór krajów ościennych. Rozpoczęła się sukcesywna krystalizacja ustroju monarchicznego. Panowanie Saula i utworzenie przez niego zjednoczonego królestwa datuje się na XI/X w. p.n.e. (ok. 1030-931 r.), nazywany przez biblistów okresem sędziów.

Według etymologii greckiej (Saoul) i hebrajskiej (S zana), imię Saul oznacza tyle, co: uproszony od Boga. Saul był synem Kisza; miał żonę Achinoam, trzech synów: Jonatana, Jiszwiego i Malkiszua oraz dwie córki: Merab i Mikal. Pochodził ze szczepu Beniaminitów, jednego z najmniejszych rodów izraelskich, określanego przez inne ludy mianem plemienia wojowniczego i ksenofobicznego. Zamieszkiwali ziemię Gibea, znajdującą się w pobliżu miast takich jak: Rama, Nob, Jerozolima, Betlejem. Biblia przedstawia Saula jako młodzieńca o nieprzeciętnej urodzie, wysokiego i dorodnego, co z pewnościa dodawało mu dostojeństwa i powagi. Z natury był on człowiekiem skromnym, który ze względu na swa postawę odpowiadał zarówno Bogu, jak i poddanym. Potrafił okazać żal i skruchę za popełniane błędy. Król-wojownik dysponował ogromną odwaga, zdolnością skutecznego opracowywania strategii wojennej, doborem i selekcją najlepszych żołnierzy. Dopiero od czasu opuszczenia go przez Boga i opętaniu przez złego ducha, zaczął popadać w coraz cięższą chorobę psychiczną2.

Istnieja dwa podania związane z wyborem Saula na króla. Pierwsza z nich opowiada o zagubieniu przez jego ojca Kisza oślic ${ }^{3}$. Wysłał więc Saula z młodym towarzyszem, aby je odnalazł. Po pokonaniu długiej drogi i bezowocnych poszukiwaniach, skłonny był do powrotu, jednak współuczestnik wyprawy przekonał go do zwrócenia się z prośbą o radę do Widzącego, czyli proroka Samuela. Mąż boży, przygotowany na jego przybycie zgodnie z wcześniejszą zapowiedzią Jahwe, zaprosił młodzieńca na ucztę i udzielił mu noclegu. O wschodzie słońca namaścił go na tarasie swojego domu na króla Izraela:

\footnotetext{
${ }^{2} 1 \mathrm{Sm}, 16,14$.

${ }^{3} 1 \mathrm{Sm}, 9,1-10,16$.
} 
„Ty więc będziesz rządził ludem Pana i wybawisz go z ręki wrogów jego dookoła "'. Ryt pomazania władcy miał charakter typowo sakralny, zawiązujący więź pomiędzy nim, a Bogiem i czyniącym z niego wasala Jahwe. Na znak prawdziwości i słusznego wyboru, duch boży zstąpił na Saula tak, że zaczął prorokować, budząc tym samym zdumienie wśród ludu. Kolejne podanie opowiada o elekcji Saula podczas zgromadzenia społeczności Izraela, oczekującej od Samuela wyboru władcy ${ }^{5}$; prorok nakazał wystapić wszystkim pokoleniom narodu wybranego. Spośród nich wyznaczył ród Beniaminitów, Bóg wskazał mu Saula, który natychmiast został okrzyknięty królem.

Za panowania Saula miały miejsce rozliczne bitwy i wojny, do czego zasadniczo sprowadzała się cała władza króla. Z reform wewnętrznych zdolał jedynie obalić i wyeliminować czarnoksiężników i wróżbitów. John Brihgt zwraca uwagę na zachowanie plemiennej organizacji poprzez niewprowadzanie innowacyjnych systemów administracyjnych czy biurokratycznych; Saul nie troszczył się również o budowę pałacu, jego siedziba miała raczej charakter twierdzy warownej. Wprowadził za to istotne modyfikacje w organizacji wojskowej, koncentrował wokół siebie młodych mężczyzn do pełnienia długotrwałej służby.

Największe zagrożenie dla Izraelitów stanowili Filistyni, zamieszkujący ziemie pomiędzy Morzem Martwym, a Morzem Śródziemnym: Gazę, Aszkelon, Aszdod, Ekron i Gat. Panowało tam pięciu przywódców, określanych jako seren, dbających o dobrą organizację i sprawne, wyszkolone wojsko, posiadające znakomite uzbrojenie ${ }^{7}$. Stopniowo podporządkowywali sobie miasta na równinie nadmorskiej, dążąc także do supremacji nad Izraelem. Ekspansjonizm zapoczątkowali zwycięską walką pod Ebenezer, mordując około czterech tysięcy ludzi i wykradając z Szilo Bożą Arkę. Jednak ich sukces nie trwał długo; pierwsza wojna filistyńska przyniosła Saulowi renomę i splendor; pokonał ich

${ }^{4} 1$ Sm, 10, 1. Cyt. wg: Biblia Jerozolimska, wyd. Pallotinum, Poznań 2006.

$51 \mathrm{Sm} \mathrm{10,17-27.}$

${ }^{6}$ J. Bright, Historia Irraela, Warszawa 1994, s. 193-194.

${ }^{7}$ Filistyni posiadali monopol na obróbkę metalu i wyroby żelazne. Aby zapewnić sobie hegemonię na Izraelem, zabronili im prowadzenia przemysłu metalowego, uzależniając ich od kowali filistyńskich. 
bowiem zarówno w mniejszych bitwach, jak i tej ostatecznej, decydującej o zwycięstwie Izraela. Warto zauważyć, że duży wpływ na wygraną miał również syn Saula, Jonatan, który jako pierwszy zaatakował nieprzygotowanych Filistynów w ich obozie w Gibea. Po upływie niedługiego czasu Filistyni zjednoczyli siły w Efez-Damim, aby ponownie uderzyć na Izrael ${ }^{8}$. To w tym miejscu odbyła się legendarna walka pomiędzy Dawidem a Goliatem, proklamująca nieuchronne zwycięstwo wojsk izraelskich przez śmierć najsilniejszego wojownika przeciwnego obozu, co faktycznie nastapiło:

Powstali mężowie Izraela i Judy, wydali okrzyk wojenny i ścigali Filistynów aż do Gat i bram Ekronu; a trupy filistyńskie leżały na drodze z Szaaraim aż do Gat i Ekronu?

Antagonistyczne stosunki z sąsiadami doprowadziły także do wojen z Moabitami, Amalekitami, Amonitami, Edomitami i mniejszymi miastami kananejskimi. Saul natchniony przez Boga, pokonał razem z trzystutysięcznym wojskiem obóz ammonicki oblegający miasto Jabesz w Gileadzie ${ }^{10}$. W czasie wojny amalekickiej Saul zgromadził czterdzieści tysięcy walczących, mordując według bożego nakazu wrogie plemię za przeciwstawienie się narodowi wybranemu w czasie jego ucieczki z niewoli egipskiej (XIII w. p.n.e.) ${ }^{11}$. Zwycięstwo zapewniło Saulowi stabilizację i bezpieczeństwo południowych granic kraju.

Jakie wydarzenia implikowały dalsze losy króla, który w tak krótkim czasie stał się szaleńcem skazanym na klęskę? Zarzewie rozwijającej się degradacji odnaleźć można już u samego początku władzy Saula, podczas świętej wojny przeciw Amalekitom. Bóg nakazał władcy, aby obłożył on klątwą wszystko, co należało do nieprzyjaciół, co w dosłownym znaczeniu oznaczało mordowanie ludzi i zwierząt. Tymczasem Saul nie wypełnił całkowicie polecenia; zadecydował o przejęciu najlepszego inwentarza i sprowadzenia go do obozu, aby tam złożyć go Bogu w ofierze. Zatem wybrał inny sposób uczczenia Boga, niezgodny z prawem. Samuel przekazał Saulowi słowa Jahwe: „Nie będziesz już

\footnotetext{
${ }^{8} 1 \mathrm{Sm} 17,1-54$.

${ }^{9} 1 \mathrm{Sm} \mathrm{17,} 52$.

$101 \mathrm{Sm} \mathrm{11,1-11.}$

${ }^{11} 1 \mathrm{Sm} \mathrm{15,1-9.}$
} 
królem nad Izraelem” i „Pan odebrał ci dziś królestwo izraelskie, a powierzył je komu innemu, lepszemu od ciebie ${ }^{12}$ ". Rozmowa odbyła się bez świadków, tak więc odrzucenie Saula nie dokonało się od razu. Jednak władca mimo ogromnego żalu i świadomości popełnionego błędu, nie był już w stanie cofnać decyzji Boga. Opuścił do duch pański, a wolne miejsce wypełnił natychmiast duch zły. Świadomość odrzucenia przez Boga wpływała niekorzystnie na temperament króla, wywołując w następstwie kryzys egzystencjalny. Pius Czesław Bosak komentuje to wydarzenie następująco:

Saul zachorował psychicznie (...), opanowała go depresja i lęki, stał się niezrównoważony i agresywny ${ }^{13}$.

Na postępujący defetyzm króla znaleziono środek zaradczy — sprowadzono młodzieńca, grającego na cytrze, aby muzyką łagodził lęki i ukoił niespokojną duszę Saula ${ }^{14}$. Król pokochał Dawida — przyszłego władcę i zatrzymał go na dworze. Te dobre relacje nie trwały jednak zbyt długo; podczas drugiej wojny filistyńskiej Dawid pokonał Goliata — jednego z najgroźniejszych przeciwników i wykazał się wielką walecznością podczas całej bitwy. W czasie powrotu do miasta kobiety witały zwycięzców, śpiewając pieśn gloryfikująca Dawida do tego stopnia, że przewyższały nią Saula ${ }^{15}$. To wydarzenie pogorszyło stan psychiczny króla. Ogarnęła go nienawiść do Dawida; od tego czasu zapragnął jego śmierci. Już następnego dnia celował w niego dwukrotnie (bezskutecznie) dzida. Następnie złożył Dawidowi obietnicę małżeństwa ze swą córką Mikal, pod warunkiem, że pokona on stu Filistynów; wierzył tym samym, że młodzieniec polegnie na polu bitwy. Dawid pomyślnie wypełnił zadanie, zyskując tym samym piękną i kochająca żonę ${ }^{16}$. Niepocieszony Saul popadł wówczas w absolutną degrengoladę; zaczął namawiać mieszkańców dworu, a nawet syna Jonatana, aby zamordowali jego zięcia. Dawid uciekł nocą do Rama, gdzie mieszkał Samuel; skonsultował się również z Jonatanem, który

$121 \mathrm{Sm} \mathrm{15,} \mathrm{24,} 28$.

${ }^{13}$ P. Cz. Bosak, Postacie Nowego Testamentu. Stownik-konkordancja, Poznań 1996, s. 634.

${ }^{14} 1 \mathrm{Sm} 16,15-23$.

${ }^{15} 1 \mathrm{Sm} 18,7$.

${ }^{16} 1 \mathrm{Sm} \mathrm{18,17-29.}$ 
potwierdził złe zamiary Saula. Władca, ogarnięty żądzą nienawiści, rozpoczął pościg za zbiegiem. Tymczasem Dawid od Samuela udał się do Nob, do kapłana Achimeleka ${ }^{17}$. Ten, nie posiadając nic innego, nakarmił go chlebem świę$\operatorname{tym}^{18}$, ofiarował mu również miecz Goliata złożony Jahwe w ofierze, znajdujacy się obok Arki Przymierza. Saul nie mogąc dotrzeć do Dawida (który w tym czasie uciekał już dalej; tym razem na krótko schronił się u Filistynów) zemścił się na Achimeleku. Wezwał go na swój dwór razem z osiemdziesięcioma czterema pozostałymi kapłanami, a następnie kazał ich wszystkich zamordować, to samo uczynił z pozostałymi mieszańcami Nob $^{19}$. John Bright nie znajduje słów usprawiedliwienia, co więcej analizuje konsekwencje występku:

Jego postępowanie musiało mu wyrządzić niepowetowane szkody i sprawiło, że wielu podawało w wattpliwość jego kompetencje. Wymordowanie kapłanów było czynem szczególnie szokującym. Czynem tym Saul zerwał wszystkie więzy z porządkiem plemiennym, a ponieważ jedyny kapłan, który ocalał z rzezi, zbiegł do Dawida, kapłani tegoż porząadku przeszli na stronę rywala ${ }^{20}$.

Dawid chronił się w jaskiniach na pustyni w Judzie i lasach w Cheret, gromadząc wokół siebie zbiegów i ludzi uciśnionych. Wystąpił również w tym czasie przeciw Filistynom grabiącym mieszkańców Keili, ratując się w ostatniej chwili ucieczka, dowiedziawszy się w porę o zasadzce Saula ${ }^{21}$. Kiedy mieszkańcy Zif donieśli królowi o kryjówce Dawida, rozpoczął się wielki pościg, początkowo po pustyni Maon (na krótki czas wstrzymał go najazd Filistynów, wykorzystujących nieobecność władcy) potem pustyni Engaddi. Biblia podaje dwa analogiczne wydarzenia ${ }^{22}$ (według biblistów uznawane najprawdopodobniej za

${ }^{17} 1 \mathrm{Sm} 21,2-10$.

${ }_{18}$ Mowa tu o tzw. chlebie pokładnym, przeznaczonym jedynie dla kapłanów. Znajdował się w Przybytku Pana, gdzie znajdowała się Arka Przymierza. W czasach Dawida spożycie tego pokarmu było niemożliwe, jedyny wyjątek stanowiła rytualna czystość, czyli wstrzemięźliwość seksualna.

$191 \mathrm{Sm} \mathrm{22,} \mathrm{6-23.}$

${ }^{20} \mathrm{~J}$. Bright, op. cit., s. 196-197.

${ }_{21} 1 \mathrm{Sm} 23,1-14$.

${ }^{22}$ Por. 1 Sm 24 1-23; 1 Sm 26, 1-25. 
dublet), mające na celu poświadczenie o szlachetności Dawida i jego szczególnej estymie, okazywanej władzy królewskiej. Pierwsze z nich opowiada o schronieniu się Saula w jaskini, gdzie akurat przebywał Dawid. Król nie widział rywala, był przy tym sam, tak że nie miał praktycznie żadnej możliwości asekuracji. Dawid po pierwszej myśli zabicia Saula odciął mu jedynie niepostrzeżenie fragment płaszcza, doświadczając później przez to wyrzutów sumienia; ubranie zastępuje bowiem osobę, która ją nosi, zatem — dotknąć ubrania, to jakby dotknąć osoby. Wtedy też udał się do króla, pokazał mu kawałek odzieży, rekonstruując minione wydarzenia i poświadczając autentyczną szlachetność swoich zamiarów. Saul zrozumiał swój błąd:

Tyś sprawiedliwszy ode mnie, gdyż odpłaciłeś mi dobrem, podczas gdy ja odpłaciłem ci złem. Dziś dałeś mi dowód, że mi dobro świadczyłeś, kiedy Pan wydał mnie w twoje ręce, ty mnie nie zabiłeś $^{23}$.

Rozmowa ta doprowadziła do pokojowego rozstania, jednak nie na długo. Analogicznie jawi się kolejna historia; tutaj Dawid zakradł się nocą do obozu królewskiego, zastał Saula śpiącego, nie otaczała go przy tym żadna straż. Jednak nie podniósł ręki na władcę, zabrał jedynie jego dzidę i manierkę na wodę, na dowód swojej obecności.

Dawid pozornie sprzymierzył się z Filistynami, aby nie dostać się w ręce $S_{\text {Saul }}{ }^{24}$. Otrzymał od króla Akisza w lenno miasto Siklag w zamian za utrzymywanie wraz ze swym oddziałem porządku na pobliskiej pustyni i obronę północnych granic. Filistyni szykowali się na zadanie ostatecznego ciosu Izraelowi. Saul, który wcześniej zabronił wywoływania duchów, udał się w nocy do ostatniej kobiety w kraju, która posiadała tę umiejętność i praktykowała ją w tajemnicy ${ }^{25}$. Bóg pozwolił ukazać się duszy zmarłego niedawno Samuela i przepowiedzieć Saulowi przyszłość — nieuchronną klęskę wojenną i śmierć.

Następnego dnia rozegrała się decydująca bitwa, w czasie której polegli trzej synowie Saula. Sam władca, osaczony przez wrogich łuczników, popadł

\footnotetext{
${ }^{23} 1 \mathrm{Sm} 24,18-20$.

${ }^{24} 1 \mathrm{Sm} \mathrm{27,1-28,2.}$

${ }^{25} 1 \mathrm{Sm} 28,3-25$.
} 
w lęk i odbierając giermkowi miecz, przebił się nim. Zwycięzcy żołnierze odcięli głowę Saulowi, jego zbroję złożyli w świątyni Asztarty, a ciało powiesili na murach swojego miasta. Dopiero mieszkańcy Jabesz przejęli ciało króla i pochowali z należnym szacunkiem ${ }^{26}$. Dawid napisał elegię o Saulu i Jonatanie:
(...) tarcza Saula
nie była namaszczona oliwa, lecz krwia poległych, tłuszczem mocarzy.
Łuk Jonatana nigdy się nie cofał, a miecz Saula nie wracal daremnie.
Saul i Jonatan, kochani i pełni uroku, za życia i w śmierci nie są rozdzieleni.
Byli oni bystrzejsi od orłów, dzielniejsi od lwów.
O, płaczcie nad Saulem, córki izraelskie: on was ubierał w prześliczne szkarłaty, złotymi ozdobami upiększał stroje. Jakże zginąc mogli waleczni, Wśród boju Jonatan przebity śmiertelnie ${ }^{27}$ ?

Śmierć Saula stanowiła nie tylko jego osobistą tragedię, ale i klęskę narodowa; umożliwiła jednak dojście do władzy Dawidowi, inicjując tym samym złoty wiek potęgi Izraela.

Analiza biblijnych dziejów i psychiki władcy pozwala wyciagnąć wnioski, jak bardzo tragiczną był on postacią. Początkowo wiele obiecująca, później stanowiąca jedynie tło negatywne, dla właściwego bohatera - Dawida.

Tragedia Saul adaptowana przez Wojciecha Bogusławskiego obficie inkrustowana jest wydarzeniami opisanymi w Pierwszej Księgi Samuela. Owe sytuacje ujęte są w dwojaki sposób: zarówno w formie bezpośredniej, stanowiącej fabułę tekstu, jak i pośredniej — poprzez sekwencje retrospektywne, gdzie bohaterowie dramatu wspominają wydarzenia wcześniejsze. Po pierwsze Dawid przypomina, jaki warunek otrzymał od Saula, aby móc poślubić Micholę (przyniesienie stu głów filistyńskich) ${ }^{28}$. Następnie pojawia się informacja

${ }^{26} 1 \mathrm{Sm} \mathrm{31,1-13.}$

${ }^{27} 2 \mathrm{Sm} \mathrm{1,} 21-25$.

${ }^{28}$ Por. W. Bogusławski, Saul, [w:] idem, Drieła dramatyczne, t. 1, Warszawa 1820, s. 3-4 oraz $1 \mathrm{Sm} 18,17-27$. 
o ucieczce Dawida i odnalezieniu schronienia w Rama, u proroka Samuela ${ }^{29}$ oraz o tymczasowym pobycie u Filistynów ${ }^{30}$. Wspomniana jest oczywiście legendarna historia walki młodego Dawida z Goliatem i pokonania go ${ }^{31}$. Achimelek wspomaga zbiegłego Dawida, zaopatrując go w żywność oraz ofiarując mu miecz Goliata, który został złożony w ofierze w Przybytku Pana ${ }^{32}$. Na koniec, zgodnie z przekazem biblijnym, Saul decyduje się zamordować Achimeleka oraz wszystkich mieszkańców Nob ${ }^{33}$.

Alfieri rozpoczyna czas fabularny w miejscu, gdzie Biblia kończy opisywać losy Saula; oto bowiem zbliża się już ostatnia, decydująca wojna pomiędzy Izraelem, a Filistynami. W oparciu o Biblię domyślić się można zatem, że następnego dnia Saul polegnie w bitwie. Jednak Alfieri zatrzymuje się w przededniu wojny, proponując Saulowi wyjście alternatywne i cofnięcie jego szaleńczych planów. Do rodzimego obozu powraca Dawid, pragnący poprowadzić naród do walki. Jego zamiary krzyżuje Abner, dowódca wojskowy, podburzający permanentnie króla; knuje podstępnie intrygi, popychające władcę do nienawiści wobec Dawida. Nieprzerwanie przekonuje go o jego niebywałej sile i potędze, sugerując, że nie potrzebuje nikogo z zewnątrz do pomocy. Saul początkowo odczuwa tęsknotę za Dawidem, ale z czasem ulega perswazji sługi, mimo usilnych działań zaradczych Jonatasa i Micholi. Dzieci nakłaniają ojca do pogodzenia się z Dawidem i zezwolenia mu na powrót (co na krótką chwilę im się udaje). Ostatecznie dochodzi do rozstrzygającej bitwy; król, widząc klęskę wojska izraelskiego, zrozpaczony żegna się ze swoimi dziećmi i rzuca się na swój miecz, popełniając samobójstwo.

Saul bez cienia wątpliwości jest postacią tragiczną. W dziele Alfieriego jawi się jako postać bezsilna, w zaawansowanym stanie depresyjnym, co najlepiej prezentuje cytowany fragment:

Och! Gdybym nie był, jak jestem, ojcem ukochanych dziatek, chciałżebym żyć, panować, zwycię-

\footnotetext{
${ }^{29}$ Por. op. cit., s. 9 oraz 1 Sm 19,18-19.

${ }^{30}$ Por. op. cit., s. 30 oraz $1 \mathrm{Sm}$ 21,11-15.

${ }^{31}$ Por. op. cit., s. 56 oraz $1 \mathrm{Sm}$ 17,32-54.

32 Por. op. cit., s. 60 oraz $1 \mathrm{Sm} 21,2-10$.

${ }^{33}$ Por. op. cit., s. 63-64 oraz $1 \mathrm{Sm}$ 22,6-20.
} 
żać? Już bym dawno znalazł śmierć, rzucając się wpośród nieprzyjaciół; dawno zwaliłbym ciężar życia, który mnie z wolna domęcza. Wieleż to już lat upłynęło, jak widziano uśmiech na moich licach! Dzieci moje, które mi są tak miłe, wzbudzaja we mnie gniew przez swoje pieszczoty... Okrutny, niecierpliwy, pożerany od zgryzot, zawsze zajątrzony, jestem ciężarem sobie samemu i tym wszystkim, którzy mnie otaczaja! W wojnie żądam pokoju; w pokoju goreję do wojny; gdy mi podaja puchar, zdaje mi się widzieć w nim truciznę; we wszystkich, którzy mnie kochaja, nieprzyjaciół znajduję... Złożony na asyryjskim łożu zdaje mi się, że leżę wśród jadowitych wężów. - Spoczynek mój jest bolesnym konaniem, sny moje okropnymi widziadły. - Na koniec, kto by uwierzył? Drżę za każdym odgłosem trąby wojennej $j^{34}$.

Targają nim mieszane uczucia, z jednej strony zdaje sobie sprawę, że Dawid jest członkiem jego rodziny, dawniej najlepszym powiernikiem i przyjacielem, z drugiej zaś - nienawidzi go całym sercem za odebranie mu autorytetu i świetności w oczach ludu. Tęskni za utraconym czasem wielkich zwycięstw, swojej sławy i chwały, podboju i obrony ziem izraelskich. Opętany żądzą nienawiści, bez cienia litości morduje Achimeleka, jednego z najwyższych rangą kapłanów i dokonuje rzezi mieszkańców miasta Nob. Popada w stany głębokiej melancholii i bezsensu istnienia, nie starając się już nawet odnaleźć zagubionej egzystencji. Traci swój dowódczy charakter, asertywność, chęć indywidualnego podejmowania decyzji, bez trudności popada w manipulacje, ulegając wpływom zarówno Abnera, jak i swoich dzieci. Ostatecznie, świadomy swojej klęski, nie jest w stanie rzucić się na wojska nieprzyjacielskie; zrozpaczony i drżący starzec przebija się mieczem.

Saul to tragedia, w której doskonale zgłębiono sylwetkę psychologiczna wielkiego władcy Izraela. Zarówno Alfieri, jak i Wojciech Bogusławski w swojej adaptacji dostrzegli tragizm tej niezwykłej postaci, nad którą ciążyło nieuniknione, boskie fatum. W Polsce sztuka wystawiona została 12 XI 1809 roku, gra w roli tytułowej przypadła samemu Bogusławskiemu. Przedstawienie oceniano wysoko, zarówno przez publiczność, jak i krytyków różnych środowisk.

\footnotetext{
${ }^{34}$ W. Bogusławski, op. cit., s. 19-20.
} 


\section{SAUL. ANALIZA I INTERPRETACJA SZTUKI}

Sześć lat po śmierci wielkiego włoskiego twórcy Vittorio Alfieriego, w 1809 roku, Wojciech Bogusławski adaptował na grunt polski jego tragedię Saul i wystawił ją na scenie Teatru Narodowego w Warszawie'. Spektakl spotkał się z wielkim uznaniem publiczności i pozytywnymi opiniami recenzentów. Badacze przyjmuja, że to właśnie Saul jest jedną z najlepszych sztuk Bogusławskiego.

Analizę utworu warto rozpoczać od eksploracji samej przestrzeni dramatu; miesza się ona bowiem ze sferą biblijna. Czerpiąc tym samym z dzieła odwiecznie zakorzenionego w kulturze, Alfieri opiera się na historii dobrze znanej już odbiorcom ${ }^{2}$. Saul wiernie oddaje przekaz biblijny, zawarty przede wszystkim w Pierwszej Księdze Samuela. Warto przy tym dodać, że przestrzeń jest częściowo zsubiektywizowana, ponieważ dostosowana została do precyzyjnego scharakteryzowania centralnej postaci dramatu.

Jak dowiadujemy się na już na samym początku tragedii, w pięcioaktowej sztuce wszystkie działania mają miejsce w wojskowym obozie króla Saula. Jest to jedyny tekst didaskaliów, umiejscawiający dramat w określonej przestrzeni. Akcja rozgrywa się pobliżu gór Gelboë w Samarii, historycznej krainie środkowego Izraela. Pozostałe informacje o przemieszczaniu się postaci dookreślane są wyłącznie w ich dialogach. I tak Michola, żona Dawida, wiele godzin spędza w samotności, kryjąc się w jaskini, znajdującej się niedaleko obozu. W tym miejscu ukrywa później Dawida:

${ }^{1}$ Zob. W. Pusz, Herkules Chylinskei — ,poeta tygodnikony”" z keregu mtodych pisaray przedromantycznej Warszany, [w:] idem, Międry Krasickim i Stowackim. Studia, eseje, opinie, wyd. Universitas, Kraków 1992, s. 42.

${ }^{2}$ Zob. J. Błoński, Præestrzeñ i dramat, [w:] idem, Problemy teorii literatury, seria 3, Wrocław 1988, s. 266-267. 
Patrzaj, widzisz w ustroniu tego gęstego lasu głęboką jaskinią. Tam to częstokroć, opuszczona od całego świata, o tobiem myślała, ciebiem wzywała i łzami boleści oblewałam nieczułe kamienie! Ukryj się w tej jaskini, aż przyjdzie czas, ażebyś się pokazał’

Kilka scen rozgrywa się w namiocie (lub jego pobliżu) Saula. To niejako punkt centralny w przestrzeni dramatu; tu odpoczywa Dawid, a wieczorem odbywa się uczta. Przed namiotem Saul prowadzi liczne rozmowy ze swoimi dziećmi. Rodzinne konwersacje odbywają się również każdego ranka, kiedy to ojciec przechadza się z potomstwem po obozie.

Jadwiga Miszalska zauważa, że czas i przestrzeń w dramacie nie służą wyłącznie realizacji założeń reguł jedności utworu:

Akcja rozgrywa się już nie w zamkniętym pomieszczeniu, lecz w obozie Izraelitów, ale prawdziwą przestrzenią dramatu jest przestrzeń psychologii Saula. Rzecz zaczyna się nocą i kończy u końca nocy, ale w rzeczywistości czasem dramatu jest czas mentalny bohatera, powracającego we wspomnieniach do wielkich chwil chwały ${ }^{4}$.

O porze dnia i upływającym czasie również informują nas postaci dramatu. Jonathas: „Noc ustępuje już dniowi; nie bawmy tu dłużej”, Saul: „Jak ten poranek jest piękny! Dziś wschód słońca nie okrywa się krwawym obłokiem'?", Michola: „Wyjdź, najmilszy małżonku, wyjdź, noc już jest ku połowie””. Dzięki tym wzmiankom odbiorca może wnioskować, iż czas akcji dramatu zawiera się w ciagu dwudziestu czterech godzin, bowiem zaczyna się noca, a kończy następnego dnia o tej samej porze.

Sama treść tragedii fabularnie zbliżona jest do historii zawartej w Biblii; jednak u Alfieriego rozpoczyna się w tym miejscu, gdzie Pismo Święte kończy opisywać dzieje Saula. Stacjonujące przy władcy wojsko wyczekuje starcia

\footnotetext{
${ }^{3}$ W. Bogusławski, Saul, [w:] idem, Džieła dramatyczne, t. 1, Warszawa 1820, s. 16.

${ }^{4}$ J. Miszalska, Historia teatru i dramatu wtoskiego, t. 1, Kraków 2008, s. 391.

${ }^{5}$ W. Bogusławski, op. cit., s. 15.

${ }^{6}$ Ibidem, s. 18.

${ }^{7}$ Ibidem, s. 68.
} 
z Filistynami, zaciekłym wrogiem od wielu dziesięcioleci. Dawid, zbiegły w obawie przed zapalczywym gniewem Saula, powraca potajemnie na wieść o bitwie. Zamierza stawić się przed królem i w niezaprzeczalnej pokorze i uniżeniu poprosić o możliwość wzięcia udziału w walce, a jednocześnie ponownego zamieszkania na dworze, przy boku swej małżonki (a córki Saula) Micholi. Najbliższa rodzina stara się przekonać panującego o bezinteresowności i czystości intencji Dawida, jednak po drugiej stronie barykady stoją zły duch i buntowniczy sługa Abner, napawający króla coraz większą nienawiścia.

Na szczególną uwagę zasługuje pierwszy fragment sztuki. Stanowi go monolog Dawida, który swoją wypowiedzią: umiejscawia dramat w określonym czasie i przestrzeni; wspomina minione czasy spokoju i dobrobytu; zapowiada finalne wydarzenia; wzywa na wojnę wrogich Filistynów. Na koniec pojawia się zdanie o charakterze moralizatorsko-refleksyjnym: „Czymże jesteśmy, kiedy nam Bóg umyka swojej opieki!".

Głównym bohaterem tragedii jest król Saul. Krótko, ale najtrafniej dążenia tej postaci charakteryzuje Ludwik Osiński określając je, jako: „największą walkę namiętności w sercu człowieka ${ }^{8}$ ". W istocie, Saul zgodnie z koncepcja twórcy ma na celu eksponowanie złożonych uczuć, a tym samym niezwykłego portretu psychologiczny władcy, którego przeznaczeniem stała się nieunikniona klęska i śmierć. Król uważa Dawida za zdrajcę, ponieważ swojego czasu schronił się u Filistynów; prawdopodobnie władcę podburzył Abner, który regularnie donosił na swojego zaciętego wroga. Abner to zły doradca; Saul poddaje się jego sugestiom i namowom, wielokrotnie morduje niewinnych ludzi, oskarżając ich o spisek i zdradę. Królowi zdarzają się przebłyski świadomości; odrzuca wówczas podszepty Abnera, jednak brakuje mu stanowczości, na skutek czego, prędzej czy później i tak ulega tym podstępnym intrygom.

Saul cierpi, udręka władcy nabiera wręcz niewyobrażalnego charakteru. Wspomnienie dawnej potęgi, niezliczonych zwycięstw, a później odrzucenia przez Boga przy jednoczesnej gloryfikacji Dawida (który od tego czasu staje się dla niego największym wrogiem) skłaniaja go ku coraz większej stagnacji. Ogarnia go poczucie bezradności i niemożliwości zmiany obecnego stanu

${ }^{8}$ L. Osiński, Drieła, t. 4, Warszawa 1862, s. 388. 
rzeczy. Mimo że Saul, podobnie jak bohaterowie wielu innych tragedii Alfieriego, otrzymuje przymioty właściwe tyranowi ${ }^{9}$, dla czytelnika tudzież widza staje się postacią wzbudzającą litość i empatię.

Wraz z rozwojem akcji, degradacja psychicznego stanu Saula ulega pogłębieniu. Bohater utworu czuje, jak bardzo jest mu potrzebna pomoc Boga i Dawida, jednak mimowolnie ją odrzuca. Jedyną ostoją dla niepocieszonego starca są ukochane dzieci; gdyby nie ich obecność, już dawno pragnąłby śmierci. Jednak w pewnym momencie i one przestają sprawiać mu radość, co więcej, doprowadzaja go wielokroć do nieuzasadnionego gniewu. Jest podejrzliwy, traci zaufanie do wszystkich, którzy go otaczaja, ma przy tym świadomość, że również oni mają o nim negatywne zdanie. Sygnalizuje to m.in. następujący fragment jego wypowiedzi:

Okrutny, niecierpliwy, pożerany od zgryzot, zawsze zajątrzony, jestem ciężarem sobie samemu i tym wszystkim, którzy mnie otaczają ${ }^{10}$ !

Władca staje się coraz mniej świadomy, popada w obłęd dokonujący w nim błyskawicznych przeskoków emocji: od nadmiernej egzaltacji wobec swoich dzieci, po żądzę zemsty i krwi, kiedy morduje kapłana Achimelecka. Dręczą go sny, w których nawiedza go zmarły prorok Samuel, wzywający go do złożenia władzy:

\section{„Saulu! Ustąp z tronu, ustąp z tronu i złóż koro- nę!” Święty, czci godny prorok, (...) ten sam Sa- muel objawia mi się teraz w ciemnościach nocy, ale $z$ twarza zagniewaną $i$ sroga ${ }^{11}$.}

Trudno opisać prawdziwe uczucia Saula do Dawida. Z jednej strony, król cieszy się z jego powrotu, kocha go tak jak dawniej, darzy go estymą za nadzwyczajne osiagnięcia na polu bitwy; za chwilę jednak obezwładnia go fala nienawiści, nieufności i podejrzeń wobec niego jako znacznie od siebie młodszego, wyniosłego uzurpatora tronu, zaszczytów i sławy. Oskarża przeto Dawida o pychę, zawiść i wywyższanie się ponad samego króla:

${ }^{9}$ Kreację bohatera-tyrana w twórczości Alfierego dostrzec można w następujacych tragediach tego pisarza: Agamemnnon, Orestes, Filippo, Spisek Pazzich, Tymoleon.

${ }^{10}$ W. Bogusławski, op. cit. s. 19.

${ }^{11}$ Ibidem, s. 22. 


\begin{abstract}
Dawidzie, ty mówisz jak człowiek wspaniały i ty byłeś nim zawsze, ale zaślepiony wyniosłością odważyłeś się gardzić mna, wynosić się nade mnie, przywłaszczać sobie sławę moję i okrywać się dostojeństwy moimi. Gdybym nawet nie był twoim monarcha, młodzian jeszcze, powinienżeś był natrząsać się z mojej starości ${ }^{12}$ ?
\end{abstract}

Niekiedy intuicja i sumienie podpowiadają mu, że Dawid w istocie jest niewinny, lecz pozytywne przeczucia tłumi ciagle obecny w nim nienawistny gniew. Istotne jest jednak to, że w dramacie faktycznie nie ma miejsca walka pomiędzy Saulem a Dawidem; pojedynek rozgrywa się wyłącznie w duszy władcy. Cóż skłania go ku tak potężnej nienawiści? Obsesyjny wręcz strach przed starością, śmiercią, samotnością i odrzuceniem splatają się w jego umyśle, doprowadzając go do zamętu myśli, obsesji i obłędu.

Saul wie, że ciąży nad nim fatum, którego dopełnienie jest nieuniknione. W poczuciu kompletnej samotności i opuszczenia, wyczuwa zbliżająca się śmierć:

Dzisiaj starożytny dąb, który ku obłokom wybujałe wznosił gałęzie, upadnie wyrwany z ziemi aż do najmniejszych korzeni. Ten dzień będzie dniem łez, krwi i śmierci ${ }^{13}$ !

oraz

Patrzaj, czy nie widzisz jak słońce krwawym otacza się kołem? Nie słyszysz żałobnego hukania sowy? Pogrzebowe jęki odbijaja się w powietrzu, przerażają me uszy i łzy wyciskają z mych oczu ${ }^{14}$ !

Ostatecznie król popełnia samobójstwo, które jest jedynym gestem poświadczającym o jego wolności. To dzięki niemu może dokonać się zjednoczenie rozdwojonej duszy i zwycięstwo nad nieprzejednanym przeznaczeniem.

$\mathrm{Na}$ uwagę zasługują również inni bohaterowie tragedii, przymnażający jej charakteru złożoności i niebanalności fabuły. Dawid jest niezastapionym żołnierzem; na wieść o zbliżającej się bitwie przybywa w pełnej gotowości do

\footnotetext{
12 W. Bogusławski, op. cit., s. 29.

13 Ibidem, s. 24.

${ }^{14}$ Ibidem, s. 42.
} 
walki. Przez krótki czas chronił się u Filistynów, lecz kiedy zainicjowali oni bitwę przeciw jego rodakom, natychmiast stał się ich przeciwnikiem. Odkąd został zmuszony do ucieczki przed królem, wojsko izraelskie pozbawione niezawodnego dowódcy ogarnęły letarg i bojaźń, żołnierze stracili dawną stanowczość i pewność siebie. To tylko podsyca Filistynów, w których pogłębia się świadomość własnej potęgi, dlatego prowokują przeciwników i pogardzaja nimi. Dawid nie lęka się Saula i nie chce dłużej przed nim uciekać; woli umrzeć na polu bitwy w imię króla i Izraela. Ukrywa się w obozie wśród żołnierstwa. Wierzy, że kiedy stanie przed obliczem władcy, zostanie uniewinniony, a podejrzenia o zdradę i winy zostaną uchylone:

O, królu! Cóż powiesz, kiedy jak niewolnik jaki schylę przed tobá poniżone me czoło? Cóż powiesz, kiedy mąż córki twojej błagać cię będzie o darowanie winy, której nie popełnił? Cóż powiesz nareszcie, kiedy twój obrońca, twój wierny towarzysz stanie przed tobą jak ofiara twej złości ${ }^{15}$ ?

Dawid jest posłuszny prorokowi Samuelowi, który przed śmiercią nakazał mu posłuszeństwo wobec króla. Przeczuwa, że wkrótce Bóg ześle na Saula karę, która dotknie nie tylko jego, ale i najbliższych. W czasie spotkania z królem Dawid wygłasza piękną mowę, w której wyraża ogromny szacunek, wierność i posłuszeństwo względem władcy. Pragnie wspomóc go w walce z Filistynami; nie myśli przy tym o własnym splendorze:

Daj mi dowództwo albo użyj mnie jak prostego żołnierza, wszystko mi równo. Niech tylko nieprzyjaciel twój zginie, niechaj czarne obłoki otaczające twój tron tchem akwilonu rozpędzone zostana; dosyć mi na tym, Saulu, w ten czas mogę umierać; w ten czas nic cię wstrzymywać nie będzie do wskazania mnie na śmierć. „Niech zginie Dawid" zawołasz, a natychmiast Abner zamorduje Dawida. — Nie będę ja się zbroił dla mojej obrony. (...) Saulu, ty mnie z niczego wyniosłeś, ty mnie poniżyć możesz; ty okryłeś mnie

${ }^{15}$ Ibidem, s. 10. 
sławą, ty mnie z niej obnażyć możesz; ty mnie na szczycie postawiłeś godności i ty mnie strącić z niego możesz ${ }^{16}$.

Kiedy przez chwilę zyskuje przebaczenie króla i możliwość udziału w bitwie, chce poprowadzić ją wraz z Abnerem. Dawid jest wyrozumiały i cierpliwy, traktuje Abnera na równi z sobą, mimo że ten wciąż szydzi z niego, zazdrosny o sławę, chwałę oraz miano wielkiego wojownika. Ostatecznie, po nieudanych pertraktacjach z królem pragnie jedynie wziąć udział w bitwie, a następnie oddalić się, by znów pędzić życie w samotności, na wygnaniu.

Dawid jest kochającym mężem, największą radość sprawia mu spotkanie z żoną Micholą, z którą nie widział się przez bardzo długi czas. Całą nadzieję pokłada w Bogu, wierząc w jego dobroć i miłosierdzie. Odczuwa wewnętrzny ból związany ze świadomością samotności małżonki i poczuciem braku stabilności rodzinnej. Żonę swą darzy ogromnym uczuciem:

Co do mojej małżonki, kocham ją tak gorącym zapałem, że uczucia, które ona wznieca w mym sercu, wyrazić mi niepodobna ${ }^{17}$.

Michola, córka Saula to kobieta, która musi dzielić swoje przywiązanie pomiędzy dwóch skłóconych ze sobą mężczyzn. Miłość, którą obdarza Dawida, stara się stłumić jej ojciec. Mimo to nie ulega perswazji, co więcej — podąża wraz z wojskiem izraelskim wierząc, iż prędzej czy później odzyska męża. Wraz z bratem modli się o uzdrowienie ojca. Chce szukać Dawida, choć ma świadomość ryzyka związanego z takim działaniem:

Słuchaj, bracie, już tu dłużej zostać nie mogę. Jeżeli pójdziesz ze mna, dopełnisz twej powinności; jeżeli nie chcesz mi towarzyszyć, puszczam się sama w ślady męża mojego; chcę znaleźć Dawida albo śmierć ${ }^{18}$.

Nie cieszą jej dobra materialne, kiedy wie, co przeżywa jej małżonek na wygnaniu. Kiedy już go spotyka, gotowa jest do największych poświęceń, by nie stracić męża po raz drugi. Przeraża ją widok bliskiej, zmęczonej osoby,

\footnotetext{
${ }^{16}$ Ibidem, s. 28-29.

17 Ibidem, s. 43-44.

${ }^{18}$ Ibidem, s. 12-13.
} 
w zniszczonej po długiej włóczędze odzieży. Dlatego tym bardziej stara się za wszelką cenę przekonać ojca do zmiany nastawienia wobec Dawida. Wyraża gotowość do porzucenia dostatku, by wieść tułacze życie przy boku męża. W przededniu bitwy namawia Dawida do ponownej ucieczki przed rozgniewanym Saulem, jednak on nie wyraża zgody na wspólną ucieczkę; wie bowiem, ile niebezpieczeństw czyha na nieznanych drogach.

Jonathan, syn Saula, wykazuje postawę szlachetną i godna pochwały, gdyż mimo obowiązującej go zasady dziedziczności tronu, z pokorą ustępuje miejsca Dawidowi, wywyższając go ponad siebie. Współodczuwa cierpienia i niepokoje szwagra, który jest dla niego najdroższym członkiem rodziny i najbliższym przyjacielem:

Odtąd, jak się oddaliłeś ode mnie, jak wiem, na jakie wystawiony jesteś niebezpieczeństwa, skazany na życie nieszczęsne, zdaje mi się, że nie walczę więcej ani za króla, ani za ojca, ani za rodzeństwo moje. Ach! Ty mi jesteś milszym nad króla, nad ojca i nad całe rodzeństwo. (...) Ty jesteś dla mnie istotą równie miłą, jak świętą ${ }^{19}$.

Jednocześnie wraz z Micholą ze zgroza przygląda się poczynaniom oszalałego ojca, starając się powstrzymać jego zapędy i nieodpowiedzialne decyzje. Obiecuje Dawidowi, że nie dopuści do jego śmierci; wie, że czuwa nad nim Bóg, który nie przyzwoliłby skrzywdzić swojego drogiego sługi.

Abner „zrodzony z krwi królów” jest sztucznym pochlebca, określa Saula przymiotami, których ten nie posiada. Oskarża zmarłego proroka Samuela, że pragnął królewskiej korony. Każdą możliwą chwilę wykorzystuje na przekonywanie Saula o podstępnych zamiarach Dawida, kiedy ten nagle pojawia się przed obliczem władcy:

\section{ABNER}

Pó $<j>$ dź, panie, do twojego namiotu. - Wkrótce przedstawię ci wojsko gotowe do boju i dowiodę ci, że Dawid nie ma nic więcej...

\section{DAWID}

Nic, oprócz niewinności swojej.

${ }^{19}$ Ibidem, s. 9. 
Co widzę?

\section{SAUL}

\section{MICHOLA}

$\mathrm{O}, \mathrm{Boż}^{20}$ !

Podburza władcę przeciw Dawidowi, a jemu samemu daje do zrozumienia, że w hierarchii znajduje się znacznie niżej, a zaszedł tak daleko nie dzięki dziedziczności, lecz wyłącznie poprzez ślub z córką króla. Zazdrości mu sławy i rozgłosu, a przede wszystkim osiagnięć na polu bitwy. Przyczynia się do śmierci Achimeleka (i mieszkańców miasta Nob), sprowadzając go przed oblicze króla i oskarżając o zdradę. Tymczasem kapłan przybył do obozu, by wstawiać się do Boga za Saulem i za wynik bitwy, która miała nastąpić (wiedział bowiem, że będzie ona klęską Izraela, ale miał nadzieję, że uda się tego nieszczęścia uniknąć).

Interesujące wydają się niektóre odautorskie zabiegi, załączone poprzez czynności wykonywane przez postaci w scenicznej przestrzeni dramatu. $\mathrm{Na}$ uwagę zasługują wypowiedzi, które w niejaki sposób zapowiadają pojawienie się kolejnych osób na scenie. Jonathas, który stoi sam, ogłasza nadejście kolejnej osoby słowami: „Cóż to za szmer obija się o moje uszy? Słyszę jakiś głos znajomy sercu mojemu." Po tej kwestii ukazuje się Dawid. Wzywany jest również przez swoją żonę Micholę, kiedy ukrywa się w jaskini: „Wyjdź, najmilszy małżonku, wyjdź, noc już jest ku połowie”. W relacji: bohater tragedii - odbiorca aktywizuje się funkcja fatyczna. Michola wprowadza czytelnika/widza w nową sytuację, zapowiada, że oto zaczyna się bitwa. Jednocześnie zachęca do udania się wraz z nią w określone miejsce; podkreśla to poprzez utożsamienie się z odbiorca, stosuje w tym celu pierwszą osobę liczby mnogiej:

Cóż to za okropny krzyk, co za jęki wychodza z namiotu mojego ojca?... Nieszczęśliwy!... Bieżmy do niego ${ }^{21}$.

Alfieri wprowadza elementy metafizyczne, co sprzeciwia się podstawowym założeniom kompozycyjnym tragedii w XVII i XVIII wieku. Posiadają jednak one ogromną wartość; nadają tragedii wydźwięku tajemniczości i niezwykłości.

\footnotetext{
${ }^{20}$ Ibidem, s. 27.

${ }^{21}$ Ibidem, s. 73.
} 
Saul widzi zmarłego Samuela, rozmawia z nim (wypowiedzi „ducha” nie są opisane, wnioskujemy o nich na podstawie wypowiedzi Saula). Widowisko budzi grozę i niepokój; oto Saul miota się w boleściach, nie może uciec przed wpatrującym się w niego bezustannie zmarłym prorokiem, który w pewnym momencie zapowiada śmierć zarówno jemu, jak i jego ukochanym dzieciom. W końcu król pada mu do nóg i błaga o litość dla Jonathasa i Micholi; dostrzega także w mistycznej wizji zbliżające się niepowodzenie wojenne; rzekę krwi i ogromną liczbę pomordowanych żołnierzy. Samuel targa go za włosy. W innym przypadku Bóg przemawia przez usta kapłana Achimeleka, który ostrzega Saula przed zbliżającą się klęską i zagłada, wskazuje nawet na zarzewie wszelkiego zła, które tkwi w Abnerze, złym doradcy króla.

O ile pierwsze cztery akty tragedii Saul cechuje niemalże stagnacja fabularna, o tyle w akcie piątym następuje gwałtowne zawiązanie akcji (Filistyni napadają i gromią nocą wojsko izraelskie) oraz jej rozwiązanie (śmierć Jonathasa, ucieczka Micholi, samobójstwo zrozpaczonego Saula). Jest to zabieg celowy; Alfieri nie zamierzał wykreować zawiłej i skomplikowanej akcji, tylko ukazać najpełniej sylwetkę psychologiczną tytułowego bohatera. Realizację zamysłu umożliwiają rozbudowane kwestie dialogowe oraz liczne monologi wewnętrzne głównego bohatera. W zawiązku z tym nie ma konieczności konstruowania fabuły z dużą liczbą postaci; autor oryginału ograniczył je wyłącznie do tych, których obecność była konieczna.

Wojciech Bogusławski dokonał przekładu Saula proza, poetycki charakter zachowały jedynie pieśni Dawida, znajdujące się w akcie trzecim. Pierwsza z nich składa się z czterech strof zbudowanych z czterech wersów o rymach przeplatanych (abab), pisanych naprzemiennie trzynasto- i ośmiozgłoskowcem. Gloryfikacja Stwórcy łączy się tu z apoteozą Saula, pochwała jego bezkonkurencyjnych osiagnięć wojennych oraz modlitwą błagalną o wsparcie na polu bitwy. Kolejny, czterowersowy Hymn, również pisany tetrastychem, zawiera rymy okalające (abba). Ukazany w podniosłej pieśni Saul jawi się nie tylko jako dobry władca i wojownik, ale również jako czuły mąż i ojciec, otoczony kochająca rodzina, której szczęścia nic nie jest w stanie zburzyć. Przy translacji ostatniej pieśni posłużył się Bogusławski dwoma strofami ośmiowersowymi pisanymi ośmiozgłoskowcem, z użyciem rymów przeplatanych. Śpiewający 
ten hymn Dawid po raz kolejny wysławia waleczność i odwagę Saula; oferuje też swoja pomoc i chęć stałego trwania u boku króla.

Wojciech Bogusławski miał świadomość różnorakich trudności, które napotka podczas podjętej przez siebie pracy przekładowej. Zaakcentował to w Uwagach nad Saulem:

Wymowa i styl, które w przekładaniu z wiersza na prozę wiele stracić koniecznie musiały, są zawsze zwięzłe, pełne mocy, ognia i głębokich myśli, jednej z drugiej wypływających. A co nad wszystko wielkiego sztuki dramatycznej znawcę w Alfierim okazuje, jest to stopniowanie namiętności, które przedstawiającemu artyście dziwnie grę ułatwiajacc, coraz mocniej zachwyca patrzących i podług woli autora wzbudza w nich litości, przestrachu, a na koniec okropności uczucia ${ }^{22}$.

Ujęcie biblijne zostało sprawnie zrealizowane za pomoca prozy, chociażby dzięki stylizacjom, nadającym przekładowi tragedii szczególnego, religijnego waloru. Decyzja Bogusławskiego o formie adaptacji zyskała aprobate ówczesnych krytyków, choć później uważano, że specyfiką twórczości Alfieriego jest charakter poetycki jego dokonań, którego nie powinno się odłączać od jego dzie ${ }^{23}$. Zgodnie z regułami gatunkowymi, tekst tragedii został napisany stylem wysokim, wyrażającym się poprzez kategorie wzniosłości, patosu i heroizmu ${ }^{24}$. Odpowiadają im określone środki ekspresji: wykrzyknienia („Okrutny Saulu!”, „O boleści!”, „Co za okropne obłakanie!”) oraz liczne pytania retoryczne („Kiedyż go zobaczę?”, „Co mówię?”, „Ale jakież mnie więzy zatrzymuja?’”). Fabuła sztuki jest mało zdynamizowana, kompozycyjna oś przewodnią stanowią dialogi, które łączą się w większe partie tekstu, składające się zasadniczo na całość sztuki. I tak dominuja wypowiedzi, w których z Dawidem rozmawiaja kolejno: Jonathas, Michola, Saul, Abner. Zabieg ten

${ }^{22}$ W. Bogusławski, Uwagi nad Saulem, [w:] idem, Drieła dramatyczne, t. 1, Warszawa 1820, s. $81-82$.

${ }^{23}$ Zob. L. Osiński, Wykład literatury porónnawczej. Teatr Wtochów. Alfieri, [w:] idem, Drieła, t. 3, Warszawa 1861, s. 34.

${ }^{24}$ Zob. hasło Tragedia, [w:] Stownik literatury polskiego ośniecenia, red. Teresa Kostkiewiczowa, Wrocław 1991, s. 635-641. 
umożliwił stopniową prezentację poszczególnych postaci, wraz z ukazaniem ich cech charakteru, przybliżeniem intencji, temperamentu oraz ze stopniowym odkrywaniem tego, co nie zawsze było widoczne od razu, w momencie ich pojawienia się na scenie.

Didaskalia zostały ograniczone do minimum; wszelkie informacje konieczne do zrozumienia fabuły tekstu autor włożył w usta bohaterów.

Przy okazji warto przyjrzeć się samej konstrukcji wypowiedzi postaci. Zgodnie z ujęciem założeń teorii literatury, jednym z głównych warunków dialogu teatralnego jest wydobywanie na jaw spraw ukrytych, zarówno w kontekście stanów psychicznych bohaterów jak i ich doznañ ${ }^{25}$. I właśnie to kryterium pełni prymarną funkcję dialogiczna. W Saulu dostrzega się znaczną przewagę kwestii długich (do kilkunastu wierszy), natomiast rzadko występują kilku- bądź jednowierszowe. Nieczęsto pojawia się również rozłamywanie wersów repliką, z uwagi na jednolity charakter ogółu wypowiedzi oraz ich doniosły, patetyczny charakter.

Zarówno w dorobku Wojciecha Bogusławskiego, jak i Vittorio Alfieriego Saul stanowił sztukę znacząca i doniosła, co poświadczyć może fakt, że obydwaj autorzy w przedstawieniach tragedii wcielili się w rolę tytułowego bohatera. Saul był ostatnia inscenizacją, w jakiej wziął udział Alfieri w Pizie w Palazzo Roncioni w 1795 roku. Bogusławski po wystawieniu Saula zyskał liczne słowa uznania, między innymi od wspomnianego już w tym wywodzie Ludwika Osińskiego, krytyka bardzo wymagającego:

Rola Saula przez JPana Bogusławskiego z największą mocą wydana, tak wszystkich zajmowała, iż nie można było prawie mieć dosyć baczenia na piękności ról innych. Wyższego tylko rzędu talentów jest cechą umieć tak rzecz zgłębić, grę stworzyć i stworzoną wykonaće ${ }^{26}$.

Pozytywną opinię po premierze w Teatrze Narodowym w 1809 roku wystawił również w „Gazecie Korespondenta Warszawskiego” anonimowy recenzent:

${ }^{25}$ Zob. S. Skwarczyńska, Koncepcja sztuki teatralnej Etienne Soriau, [w:] eadem, Wokót teatru i literatury, Warszawa 1970, s. 41-44.

${ }^{26}$ L. Osiński, Dzieła, t. 4, Warszawa 1862, s. 388. 
JPan Bogusławski grał Saula. Kto go widział w roli Leara, i w tej go sobie - nie widziawszy - wystawić potrafi, z tą różnica, iż rola Saula więcej natężeń wymaga, więcej pracy grającego, więcej wzruszenia $[\ldots]$ kosztowała widza. Powiemy krótko: gdyby Alfieri był przytomnym tej reprezentacji, policzyłby ja zapewne między najmilsze swej pracy nagrody ${ }^{27}$.

Historia biblijnego Saula zainspirowała nie tylko Vittorio Alfieriego, ale i twórców wcześniejszych. W 1763 roku Voltaire wydobył z Biblii starotestamentalny wątek izraelskiego króla, jednak wykorzystał go przewrotnie, przeciw Kościołowi, co oczywiście nie dziwi w podejściu tego wiodącego wówczas libertyna do biblijnego tematu. Saul mimo swego niewątpliwego szaleństwa, w adaptacji francuskiego pisarza przedstawiony jest o wiele bardziej humanitarnie, niż u Alfieriego. Voltaire wprowadza dodatkowego bohatera, Bazę, który sugeruje, że Dawid i Samuel buntują się przeciwko władcy. To Dawid, ukazany w negatywnym świetle, pełni rolę dającego się przekupić narzędzia kapłanów. Voltaire zwraca również uwagę na relacje miłosne wiążące Saula i Abigail (żonę Dawida), która bez oporów przystaje na zaloty króla ${ }^{28}$. Przekładu Saula pióra Voltaire’a dokonał w Polsce w 1789 roku Ignacy Jaxa Bykowski — (ur. 1750, zm. po 1817) poeta, dramatopisarz, tłumacz. Jak błędnie podaje Estreicher, tekst Bykowskiego, Saul. Tragedia uyjęta z Pisma Świętego, został napisany przez Pierre’a Daniela Hueta, a jedynie przetłumaczony przez Voltaire’a, co z niewielkimi zmianami powtórzono w oświeceniowej części Nowego Korbutat²9 Tymczasem autorem tekstu był sam Voltaire; być może pomyłka nastapiła na skutek pseudonimu: Huet, umieszczonego pod tekstem tragedii ${ }^{30}$. Bykowski przetłumaczył i wystawił Saula w 1789 roku, kryjąc się pod nazwą „Lipsko-war-

27 Z. Wołoszyńska, Wojciech Bogusławski wobec wrorów dramaturgii zachodnioeuropejskiej, [w:] Antynomie Ośmiecenia. Tom specjalny w 200 rocznice Konstytucji 3 Maja, Wrocław 1991, s. 240.

28 Zob. M. Siebeck, Saul in story and tradition, Germany 2006, s. 323-327.

29 Zob. Ignacy Jaxa Bykowski, [w:] Bibliografia literatury polskiej. „Nowy Korbut”, opr. E. Aleksandrowska z zespołem, red. tomu do r. 1958 T. Mikulski, t. 4, Warszawa 1965, s. 336. W dziele Twórçość znajdujemy tu informację: „Saul. Tragedia wyjeta z Pisma Świętego. Lipsk (Warszawa) 1789. Wg utworu P.D. Hueta w przekładzie Voltaire'a”.

30 Zob. Wolter, [w:] Polska bibliografia wolnomularstwa. Cąsí I. Druki do 1850 roku, red. M. B. Stępień, Lublin, 2012, s. 62-63. 
szawskiego dyjabła”. Sztuka spotkała się z krytyką Karola Surowieckiego, pisarza religijnego i tłumacza, który z kolei napisał w 1792 roku sztukę: Python lipsko-warszawski diabel. Kontr-tragedia na tragediq Saul uyjeta z. Pisma Świętego ${ }^{31}$. Dzieło w lekki i zabawny sposób ukazuje sąd nad Pythonem, który kolejno sprawują: Bóg, Michał Anioł, Dawid i Samuel.

Saul Bogusławskiego wzbudzał zainteresowanie wśród wielu twórców późniejszych epok. Już w 1829 roku Adam Mickiewicz gromadził materiały na temat Bogusławskiego i jego dzieł z zamiarem napisania rozprawy, której nigdy nie ukończył. Interesowały go szczególnie dramaty, zwierające aluzje do aktualnej sytuacji politycznej w kraju. Dwudziestowieczny badacz dramatu i teatru, związany z łódzką uczelnia, Stanisław Kaszyński zauważył w jednej ze swoich rozpraw, iz tragedia Saul „przez ukazanie postaci dumnego i okrutnego króla Saula, którego poczynaniom przeciwstawia się szlachetne męstwo i poświecenie dla dobra ojczyzny Dawida, był niewatpliwie i przyjmowany jako oskarżenie despotyzmu i jedynowładztwa ${ }^{32}$ ".

Sztuka Alfieriego wywarła duży wpływ na ówczesnych malarzy. Przyjaciel domu Vittoria i Luisy d'Albany, François-Xavier Fabre po obejrzeniu biblijnej sztuki w rezydencji florenckiej namalował obraz: Saul dreczony uyrzutami sumienia na widok ducha Abimelecha ${ }^{33}$. Warto również wspomnieć, że sam temat ujął również polskiego artystę, Antoniego Brodowskiego, który malował Gniew Saula na Dawida, eksponowany w 1819 roku na pierwszej wystawie dzieł sztuk pięknych w Warszawie ${ }^{34}$.

Tragedia Vittorio Alfieriego poprzez zakorzenienie w tradycji biblijnej, ale i dzięki niezwykłym portretom psychologicznym oraz metafizycznym wizjom króla Saula, wywołała zainteresowanie wielu twórców — nie tylko Bogusławskiego, ale i Byrona, Lamartine’a, Augusta von Olatena, którzy zainspirowani tą sztuką stworzyli własne dzieła.

${ }^{31}$ Bibliografia literatury polskiej. „Nowy Korbut”, op. cit., t. 5, Warszawa 1970, s. 247; tu ponadto dopisek: ,Z Pythonem polemizował Kapostas”.

${ }^{32}$ S. Kaszyński, Uwagi o teatrze wileńskim w czasach Mickiewicza, [w:] „Prace Polonistyczne”, seria XIII, Wrocław 1957, s. 210.

${ }^{33} \mathrm{~W}$ tym czasie Fabre był już znanym malarzem, po wcześniejszych sukcesach i zwycięstwach, między innymi za obraz: Nabuchodonozor zabija synów Sedecjasza na oczach ojca. Po śmierci Alfieriego zaopiekował się Luizą i pozostał jej wiernym towarzyszem do ostatnich chwil życia. Zob. Maria Niemojowska, Ostatni Stuartowie, Warszawa 1992, s. 278-279.

34 Zob. Z. Wołoszyńska, op. cit., s. 239. 


\section{PRZEKAZY SAULA. REKONESANS BADAWCZY}

W 1809 roku Wojciech Bogusławski adaptował tragedię Saul z włoskiego oryginału pióra Vittoria Alfieriego. Sztuka została wystawiona na deskach Teatru Narodowego w Warszawie w tym samym roku, a jedenaście lat później weszła w skład pierwszego tomu Dzieł dramatycznych. Jednak nie jest to jedyna wersja Saula. Kolejnej adaptacji dokonał we Lwowie Karol Łopuszański (ur. 1782 — zm. 1818), aktor i autor dramatyczny (tłumacz) w Teatrze Polskim Jana Nepomucena Kamińskiego oraz redaktor „Gazety Lwowskiej” (od 1810 r.) i „Pamiętnika Lwowskiego” (od 1816 r.). Trzeba bowiem postawić pytanie: czy na pewno jest to przekład jego autorstwa?

W teatrze lwowskim tragedia jako gatunek miała ugruntowaną tradycję, popartą kilkudziesięcioletnią żywotnością. Realizowała dwa podstawowe postulaty: posiadanie cech nadających jej charakter „naturalności” oraz morał wynikający z fabuły dzieła. Niestety, na tragedie chodzono we Lwowie do teatru rzadko i niechętnie. Ówczesny dyrektor, J.N. Kamiński, mimo wszystko wystawił około sześćdziesięciu tragedii, za to nie wznawiał ich zbyt często. Najchętniej wybierał dzieła znanych twórców: Voltaire’a (Alzyr, Mahomet), Corneille’a (Cyd, Horacjusze), Racine’a (Fedra, Mitrydat) i w końcu Alfieriego - Saul oraz Wirginia. Fakt czterokrotnego wznowienia Saula (którego premierowe przedstawienie odbyło się 13 III 1815) poświadcza o niemałej popularności i zainteresowaniu publiczności tą sztuką.

Kamiński w czasie dyrekcji Bogusławskiego we Lwowie, uczył się od niego pisarskiego warsztatu: reguł gry aktorskiej, nasycania sztuk aluzjami politycznymi, dydaktyzmu i moralizatorstwa. Później, kiedy sam został kierownikiem Teatru Polskiego, korzystał z pomocy i rad swojego wieloletniego mistrza. 
Warto w tym miejscu dodać, iż Wojciech Bogusławski dysponował obszerną biblioteczka. Wśród licznych publikacji swoje miejsce miała między innymi literatura angielska: Pieśni Osjana w tłumaczeniu Ignacego Krasickiego oraz liczne czasopisma: „Pamiętnik Warszawski”, „Kalendarzyk Polityczny”, „Sybilla Nadwiślańska”, „Pszczółka Krakowska”, „Rocznik Teatru Narodowego Warszawskiego" i inne ${ }^{1}$. Być może, w czasie odwiedzin w domu Bogusławskiego, przeglądając jego księgozbiór, Kamiński natknął się na tomik dzieł Alfieriego, które Bogusławski także posiadał. W 1815 roku, czyli sześć lat po wystawieniu Saula na scenie Teatru Narodowego w Warszawie, ukazał się on również na deskach teatru lwowskiego. W tym czasie Bogusławski powrócił już do Polski.

Zofia Wołoszyńska oraz Barbara Lasocka w swoich pracach badawczych informuja, że Karol Łopuszański dokonał przekładu Saula z języka włoskiego ${ }^{2}$. Ponadto Zofia Wołoszyńska zamieściła błędną informację o zaginięciu rękopisu Łopuszańskiego ${ }^{3}$. Tymczasem znajduje się on w Bibliotece Śląskiej w Katowicach. Jego faktyczne istnienie, umożliwiające uważną lekturę i porównanie z tłumaczeniem tragedii pióra Bogusławskiego, prowadzi do zaprzeczenia oryginalności autorstwa przekładu Saula, dokonanego jakoby z języka włoskiego przez Karola Łopuszańskiego.

Analizując poszczególne partie tekstu ${ }^{4}$ (w tłumaczeniu Bogusławskiego i Łopuszańskiego) dostrzec można, że przekazy są niemalże identyczne. Około

${ }^{1}$ Badania nad księgozbiorem Wojciecha Bogusławskiego przeprowadziła prof. Maria Wichowa, zob. idem, Życie kulturalne w parafii Lubochnia do czasów powstania listopadowego, [w:] Drieje Lubochni. Miejscowość, kościót, ludzৃie, red. ks. Waldemar Gliński, Łódź 2011, s. 105-107.

${ }^{2}$ Zob. Z. Wołoszyńska, Wojciech Bogusławski wobec wzorón dramaturgii zachodnioeuropejskiej, [w:] Antynomie Ośniecenia. Tom specjalny w 200 rocznice Konstytucji 3 Maja, Wrocław 1991, s. 237 i B. Lasocka, Teatr lwowski w latach 1800-1842, Warszawa 1967, s. 362. Także w Bibliografii Literatury Polskiej „Nowy Korbut”. Oświecenie, oprac. E. Aleksandrowska z zespołem, red. tomu do r. 1958 T. Mikulski, t. 6/1, Warszawa 1970, s. 630, wśród przekładów autorstwa K. Łopuszańskiego znajdujemy jako pozycję nr 8: „V. Alfierii: Saul. Tragedia w 5 aktach".

${ }^{3}$ Z. Wołoszyńska, loc. cit.

${ }^{4}$ Por. W. Bogusławski, Saul [w:] idem, Drieła dramatyczne, t. 1, Warszawa 1820 oraz K. Łopuszański, Saul, Śląska Biblioteka Cyfrowa, rkps, sygn. 705. 
85\% objętości dzieła w obu przypadkach przybiera taką samą postać. Pozostałe $15 \%$ obejmuje:

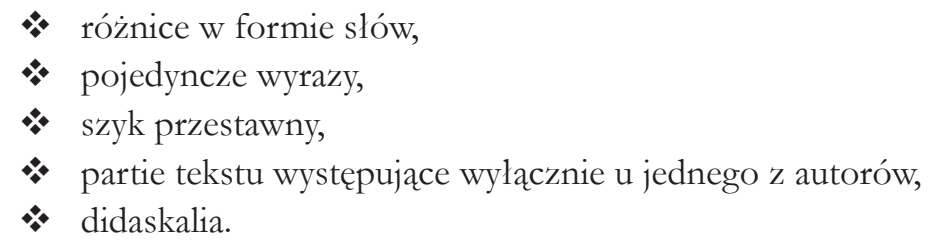

Wariantywność w obrębie słów dotyczy przede wszystkim gramatycznej kategorii fleksji imiennej i czasownikowej. Warto wspomnieć tu chociażby o formach zaimka: twoja / twoje, swoja / swoje, mie / mnie, crasowników: otoczyt / otaczat, rzucita / zrzucita, rzeczowników: przed oczy / przed oczyma, przeczucie / pržeczucia, mojej ojçyzny / mojej ojçyżnie itd. Ponadto Bogusławski w nazwach własnych pełniących w utworze funkcję fatyczną w przeciwieństwie do Łopuszańskiego stosuje formy mianownika: Abner zamiast Abnerze, Dawid zamiast Dawidżie. W wersji Łopuszańskiego pojawiają się także nieprawidłowo zapisane wyrazy z terminologii biblijnej: Galboe zamiast Gëlboe (akt I, scena I), eszodon zamiast efodon (akt III, scena IV). Równocześnie jednak warto zauważyć, że zarówno w przekładzie Bogusławskiego, jak i Łopuszańskiego znajdują się identyczne formy wyrazów w przypadkach, gdzie powinny stanowić one raczej cechę indywidualną, charakterystyczną dla stylu jednego autora: wskazatés zamiast skazałés (akt I, scena I), nadgradza zamiast nagradza (akt I, scena II), puharów zamiast pucharów (akt I, scena I), źrzódła zamiast źródła (akt II, scena I), w mych ręku zamiast w mych rekach (akt II, scena I), jednego poranku zamiast jednego poranka (akt II, scena III) itd. Fakt ten może potwierdzać założenie o przejęciu przetłumaczonego już dzieła przez jednego z autorów.

Istotne różnice pojawiają się obrębie pojedynczych wyrazów. Pojawiające się odmiennie słowa mają najczęściej charakter synonimów lub są pokrewne konotacyjne: 


\begin{tabular}{|c|c|}
\hline BOGUSŁAWSKI & LOPUSzAŃSKI \\
\hline uciec & umknąć \\
\hline niebytność & nieprzytomność \\
\hline góry & szańce \\
\hline z radością & z ukontentowaniem \\
\hline pomyślność & szczęście \\
\hline bóle & boleści \\
\hline góry & okopy \\
\hline ujść & uniknąć \\
\hline pustynia & ustronie \\
\hline chwila & moment \\
\hline fortunny & przyjemny \\
\hline zgryzoty & troski \\
\hline modły & prośby \\
\hline
\end{tabular}

Zdarzają się również przypadki (bardzo nieliczne, pojedyncze), w których zdania przetłumaczone są inaczej: Ona doczekuje dnia na samotnym swym tożu (Bogusławski) - Oczekuje dnia samotna wśród posępnej nocy (Lopuszański); Któryż. rycerz. zodoła sie z nim porównać? (Bogusławski) - Czyliz jego szlachetna postawa nie potrafi go zdradzić? (Lopuszański).

Największą różnicę pomiędzy tekstami zauważa się w zakresie szyku przestawnego, stosowanego przez obu autorów. Zmieniana jest kolejność dwóch, trzech wyrazów, rzadziej większej liczby elementów, np.: wielkiego præ̌edsięwðięcia / przedsiewzięcia wielkiego, w pałacu samotna / samotna w pałacu, daleko jesteś od nas / od nas daleko jesteś, moja matżonka / matżonka moja itd.

Partie tekstu występujące wyłącznie u jednego z tłumaczy to zjawisko incydentalne. Zjawisko to ogranicza się bodajże do trzech, czterech sekwencji. U Łopuszańskiego wykrzyknienia: To Jonathas!, Panie! oraz O Dawidzie! nie znalazły się w objaśnieniu Bogusławskiego, u którego z kolei zdanie: Kiedy zbiegly pomiedzy Filistyny, pedziłem dni wystepne w porozumieniu z zdrajcami ukrytymi w obozie naszym (akt II, scena III) — nie znalazło miejsca u Lopuszańskiego. 
$\mathrm{Na}$ osobne omówienie zasługują didaskalia, ponieważ ich obecność znacznie przeważa w tekście Łopuszańskiego. W wielu miejscach, gdzie następuje zakończenie określonej sceny, Bogusławski nie zamieszcza tekstu pobocznego. Inaczej ma się rzecz u Lopuszańskiego: $W$ chodza do namiotu (akt II, scena III), Abner odchodzi (akt III, scena I) itd. W akcie III, scenie IV w przekładzie Bogusławskiego didaskalia poprzedzające Hymny informuja, że Dawid jest ich wykonawca: siada z drugiej strony i praygrywajac mu na barfie, śpiewa z poczatku cichym glosem, który potem staje sie coraz, mocniejsaym w miare ræeçyy, jakie opiewa ${ }^{5}$. Łopuszański przedstawia tę scenę zupełnie inaczej: oto Saul wspiera swoją głowę na ramieniu Micholi, tymczasem Hymny śpiewa Jonathas, Dawid siada troche w tyle i praygrywa na harfie, która z namiotu Saula tym razem praynióst ${ }^{6}$. Hymmy przerywane dialogami uczestników spotkania poprzedzaja wskazówki o sposobie śpiewu Jonathasa, np. śpiewa w spokojniejszej iprayjemniejszej melodii ${ }^{\top}$.

Argumentem przemawiającym za niemożliwością dokonania przez obu autorów indywidualnych przekładów jest forma Hymnów, która w obu przypadkach jest identyczna. Ze względu na strukturę wynikającą z reguł gatunkowych hymn musi specyfikować się zrytmizowaniem, określoną liczbą sylab oraz rymami. Nie ma możliwości, aby podczas tłumaczenia takiej zrygoryzowanej formy z języka obcego (tu: włoskiego), dwóch tłumaczy dokonało identycznej translacji.

Któż zatem skorzystał z objaśnionego już tekstu? Nie należy odrzucać przy tym możliwości, że opierając się na gotowym przekładzie, Łopuszański mimo wszystko posiadał włoski oryginał (co potwierdza fakt nielicznych różnic w tekstach). Hipotetycznie przekładu mógł dokonać nawet Jan Nepomucen Kamiński, który w czasie przebywania Bogusławskiego we Lwowie wykonywał dla niego tłumaczenia pomniejszych sztuk, również z języka włoskiego ${ }^{6}$. Przyjrzyjmy się zatem charakterom pisma poszczególnych autorów:

${ }^{5}$ W. Bogusławski, op. cit., s. 48.

${ }^{6}$ L. Bernacki, Jan Nepomucen Kamiński [w:] Stulecie Gazety Lwowskiej 1811-1911, t. 1, cz. 2, Lwów 1911, s. 16. 
Rękopis Jana Nepomucena Kamińskiego ${ }^{7}$ :

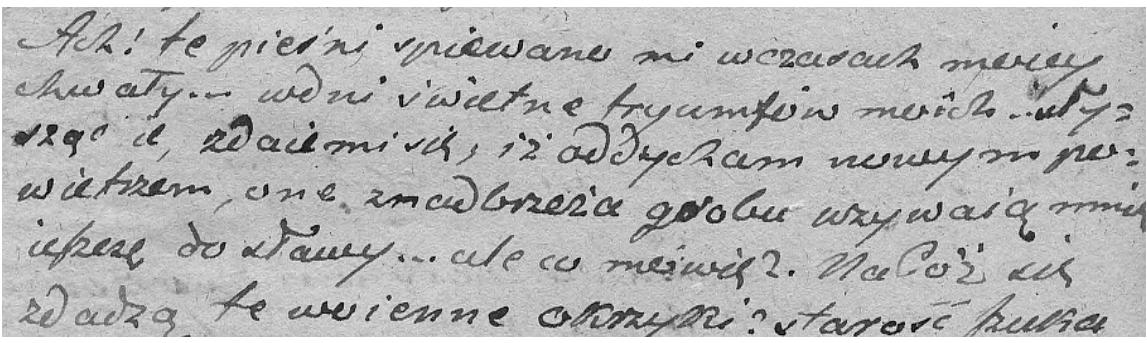

Rękopis Karola Łopuszańskiego ${ }^{8}$ :

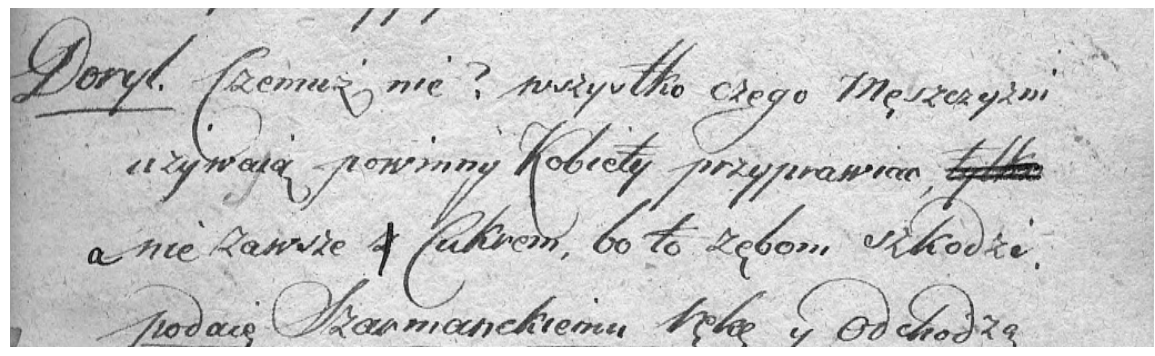

Rękopis Wojciecha Bogusławskiego':

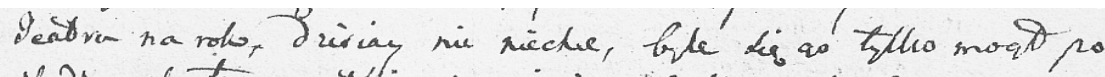

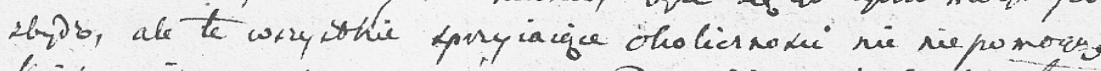

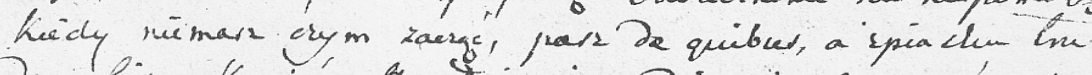

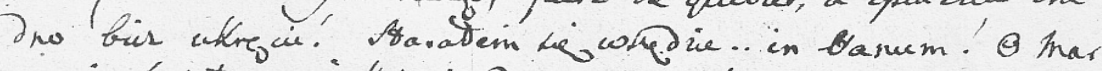

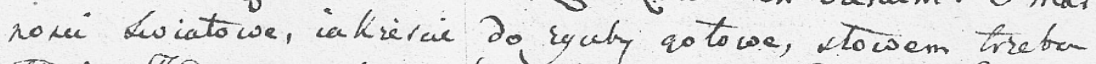

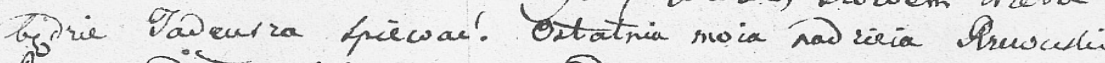

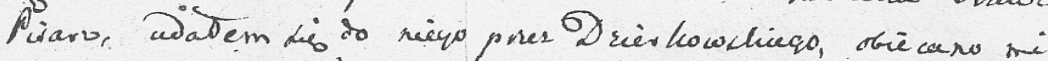

${ }^{7}$ J. N. K, Zamieszanie, Lwów 1809, rkps, Śląska Biblioteka Cyfrowa, sygn. 821.

${ }^{8}$ K. Lopuszański, op. cit., s. 21.

${ }^{9}$ Rkps Wojciecha Bogusławskiego przechowywany w zbiorach Biblioteki Narodowej w Warszawie, list dat. Lwów, V 1796, adresat nieznany. 
Bardzo zbliżony, ale jednak nie identyczny charakter pisma Bogusławskiego i Łopuszańskiego wyklucza możliwość wręczenia lwowskiemu tłumaczowi oryginalnego skryptu, już uprzednio przetłumaczonego przez polskiego dyrektora. Pozostaje więc tylko pytanie: w jaki sposób Saul Bogusławskiego dostał się w ręce Łopuszańskiego? Nie mógł skorzystać z Drieł dramatycznych, bo wydane zostały dopiero w 1820 roku, a premiera Saula we Lwowie miała miejsce w roku 1815. Być może, po warszawskim wystawieniu Saula w 1809 roku, Kamiński poprosił Bogusławskiego o przesłanie skryptu? A może Lopuszański udał się do Warszawy, by w oparciu o tomik dzieł Alfieriego (który Bogusławski posiadał) oraz o gotową adaptację z 1809 roku stworzyć swoje, tak bardzo zbliżone tłumaczenie? Na tym etapie badań trudno to udowodnić. Można co najwyżej snuć dalsze przypuszczenia, jednakże analiza i porównanie obydwu tekstów (możliwe dzięki odnalezieniu rękopisu Łopuszańskiego), potwierdza bardzo ważny fakt, iż Lopuszański nie dokonał przekładu Saula indywidualnie, że musiał opierać się o wersję Wojciecha Bogusławskiego, którą miał w swym zasięgu i wykorzystał.

Kolejnym zagadnieniem, nad którym warto się zatrzymać, jest kwestia cenzury we Lwowie. Na skrypcie teatralnym Saula, stanowiącym rękopis Karola Łopuszańskiego, umieszczone są wpisy i skreślenia cenzorskie.

Przyjrzyjmy się dziejom cenzury na ziemiach austriackich. Już od czasów Ferdynanda II działała tam tzw. komisja cenzuralna. Maria Teresa rozdzieliła cenzurę na duchowną (wykonywaną przez ordynariaty biskupie) i państwowa, nazywaną we Lwowie expozyturą cenzuralna, wykonywana przez radcę gubernialnego. Gouverneur był reprezentantem cesarza w terenie i zwierzchnikiem całej administracji politycznej w kraju ${ }^{10}$. Należał on do organu Dyrekcji Policji, do którego obowiązków, jak pisze Antoni Kurka, należały:

Dochodzenia i karania w sprawach nieprawnych ograniczeń wolności lub obrazy czci, które według \1339 austr. ustawy cywilnej należą do zakresu urzędowania władzy politycznej, cenzura teatralna i czasopism krajowych oraz tych cza-

${ }^{10}$ Zob. M. Matniak, Rada administracyjna miasta Krakowa i jego okeregu: Z dziejów XIXwiecznej administracji krakowskiej, Warszawa 2011, s. 162. 
sopism zagranicznych, które nie zostały sprowadzone przez Wiedeń ${ }^{11}$.

Książki, manuskrypty i rysunki od 1810 roku trafiały w ręce pracowników odrębnego urzędu, nazywanego Bücher-Revisions-Amt. Co więcej, w 1811 roku cesarz Józef II wydał rozporządzenie, zgodnie z którym łamanie obowiązujących nakazów, związanych z publikowaniem i upowszechnianiem treści, karane było ciężkimi represjami ${ }^{12}$. Także wytyczne zawarte w późniejszej ustawie prasowej (z 1843 roku) precyzyjnie określały, o czym można pisać, a co jest stanowczo zabronione. Do ówczesnego gubernatora Stadiona skierowano żądanie zniesienia cenzury, co też uczynił w marcu 1848 roku; jednak nie było to całkowite zniesienie restrykcji ${ }^{13}$. Twórcy i drukarze odetchnęli z ulga jedynie na siedem miesięcy, po których nastąpił nawrót kontroli, jeszcze bardziej rygorystyczny niż dotychczas.

Bolesny efekt cenzury dawał się odczuć twórcom w wielu aspektach. Najczęstszym problemem było długoterminowe przetrzymywanie tekstów przez cenzorów, zalegających na biurkach osób „kontrolujących” nawet latami. Jednak najbardziej obawiano się samej weryfikacji tekstów, które były niejednokrotnie odsyłane do korekty, co za każdym razem pociagało za sobą kolejne koszty. Czesi i Niemcy, sprawujący przeważnie funkcję cenzora, nie znali dobrze języka polskiego, wykreślali więc treści w nadwyżce, aby nie narazić swojego stanowiska. Cenzorzy zostawiali jedynie notkę, czy tekst nadaje się do upublicznienia, nie podpierając decyzji żadną argumentacją (dokładnie w ten sam sposób postapił Zajączkowski na skrypcie Saula). Twórcy z obawa spoglądali na swoje zwrócone dzieła, z nadzieją, że nie ujrzą na niej podpisu non admittitur, zakazującego publikacji1' ${ }^{14}$ Jednak, jak wspomina Kazimierz

${ }^{11}$ A. Kurka, Drieje i tajemnice lwowskiej policji, Lwów 1930, s. 13.

${ }^{12}$ Przede wszystkim były to wysokie kary finansowe, konfiskata nakładu lub odebranie koncesji. Zdarzały się również nierzadko więzienia (od kilku dni do wielu lat), skazanie na banicję oraz represje cielesne, np. chłosty.

${ }^{13}$ Odpowiedzialnością za ukazujące się treści obarczył Stadion drukarzy, zabraniając im przyjmowania treści uderzających w religię, obyczaje i porządek publiczny. Wprowadził również system kar za nadużycie lub łamanie prawa.

${ }^{14}$ Zob. W. Bruchnalski, Czasopiśmiennictwo galicyjskie 1773-1811, [w:] Stulecie Gazety lwowskiej, t. 1, cz. 1, s.4. 
Ostaszewski-Barański: „najgroźniejszą była formuła typum non meretur, zapowiadająca, że i najdalej idące zmiany w tekście nie pomogą ${ }^{15}$ ". Wielokrotne wizyty w urzędach kończyły się upokarzaniem i lekceważeniem autorów, a nawet wyrzucaniem ich za drzwi. Nieznany autor Uwag nad literatura w Galicii trafnie ocenił działalność cenzury:

Literatura galicyjska i cenzor mają się w prostym stosunku. Im lepszy był cenzor, im strawniejszy miał żołądek, im humor weselszy, im więcej w szczęśliwszej chwili pochwycił rękopis do ręki, tym lepszą była literatura. (...) Cenzor galicyjski jest w urzędzie swoim wszechmocny; nie trzyma się on żadnych praw ani przepisów, nie jest obowiązany usprawiedliwiać swoich dowolności (...). Wolno mu, przekreśliwszy rękopis, napisać: Nie warto drukować. A przecież na druk nie daje pieniędzy. Wolno mu z rękopisu porobić sobie zapałki do lulki, zarzucić go lub oddać autorowi poszarpany, zatłuszczony i niezupełny, na dowód, jak mało na uwagę i poszanowanie zasługuja prace umysłowe ${ }^{16}$ !

Przyjrzyjmy się teraz bliżej rękopisowi skryptu Saula Karola Łopuszańskiego. Na pierwszej stronie widnieje wpis cenzora Zajączkowskiego. Jest to postać nieznana; jak do tej pory nie udało się ustalić jego tożsamości. Znikome adnotacje na temat Zajączkowskiego odnaleźć można u badaczy takich jak Schnür-Pepłowski i Anna Aleksiewicz ${ }^{17}$. Z informacji wynika jedynie, iż był to człowiek wyjątkowo okrutny i rygorystyczny. Sam przydomek nadany mu przez obcujące z nim środowiska — „Wielki inkwizytor” wystarczająco pozwala się domyślić, jak mogła wyglądać współpraca z Zajączkowskim. Brał udział śledztwach i rozstrzygał sprawy o skomplikowanym przebiegu. W 1833 roku na skutek szczególnego nasilenia druku broszur politycznych

${ }^{15}$ K. Ostaszewski-Barański, Z driejón cenzury, [w:] Stulecie „Gazety lwowskiej”, t. 2, cz. 4, s. 76.

${ }^{16}$ Cyt. za: ibidem, s. 77.

17 Zob. S. Schnür-Pepłowski, Bogusławski we Lwowie. Ustęp z dziejón sceny polskiej 1795-1799, Lwów 1895, s. 283-284; A. Aleksiewicz, Kontakty wydawcón i drukarzy lwowskich z cenzura austriack a pierwszej potowie XIX wieku, [w:] Kraków - Lwów: ksiażki, czasopisma, biblioteki XIX i XX wieku, t. 6, cz. 2, Kraków 2003, s. 21. 
we Lwowie, wprowadzono prokuratora i przeprowadzono śledztwo, które jednak nie przyniosło oczekiwanego skutku. Dopiero kiedy sprawą zajął się „znienawidzony” Zajączkowski, odnaleziono źródło powstawania tajnych prospektów w drukarni Ossolińskiej. Decyzja „Inkwizytora” zakład zamknięto na wiele lat, a kilka osób aresztowano. Zajączkowski bardzo dbał o swoje bezpieczeństwo i zawsze przebywał w towarzystwie policjanta. Jednak mimo tego, nieznany zbójca zamordował go strzałem w głowę noca, piątego lipca 1847 roku $^{18}$.

Pozostaje tylko pytanie, czy ten sam Zajączkowski mógł być cenzorem sztuk teatralnych, wystawianych przez Kamińskiego? Wiadomo, że w czasie urzędniczej pracy obejmował wiele stanowisk. Przegląd zasobów lwowskiej biblioteki cyfrowej wskazuje, że Zajączkowski wielokrotnie oceniał sztuki teatralne. Pierwsze wpisy datowane są na rok 1819, ostatnie - 1828. Być może to właśnie ten Zajączkowski pełnił w tym czasie funkcję cenzora.

$\mathrm{Na}$ każdym skrypcie teatralnym widoczny jest ten sam wpis, dokonany w języku niemieckim, niżej znajduje się miejsce (Lemberg, czyli Lwów) i dokładna data sygnatury.

Zapis na skrypcie Saula:

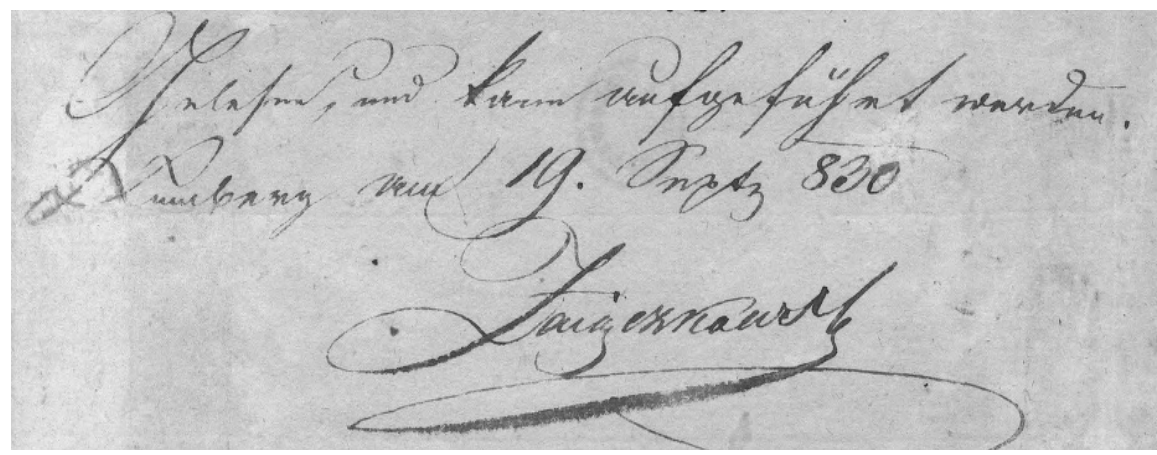

Dla porównania, warto obejrzeć kilka innych skryptów.

${ }^{18}$ R. Sadaj, Kto byt kim w Galicij, Kraków 1993, s. 276-277. 
Sam z soba sie wybit, komedia, 1824

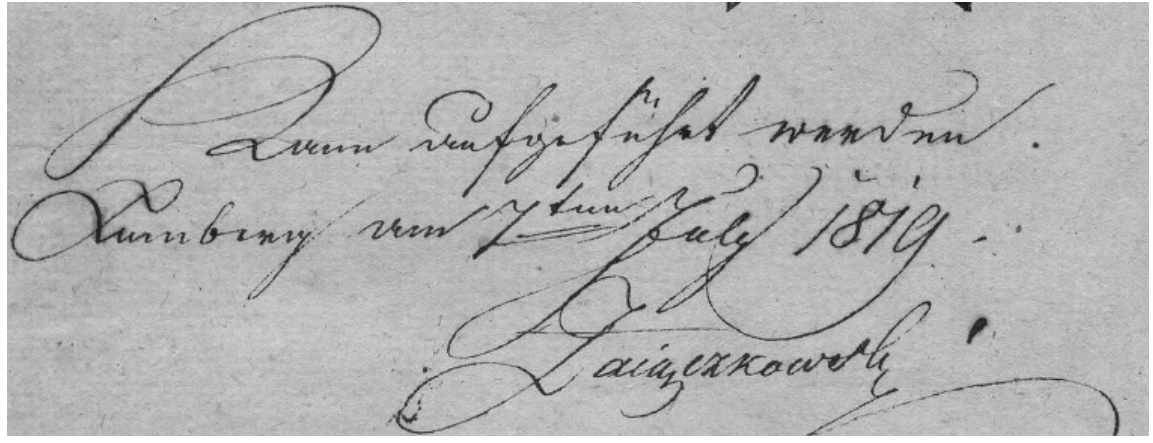

Upominek Ksiażecia, komedia, 1826

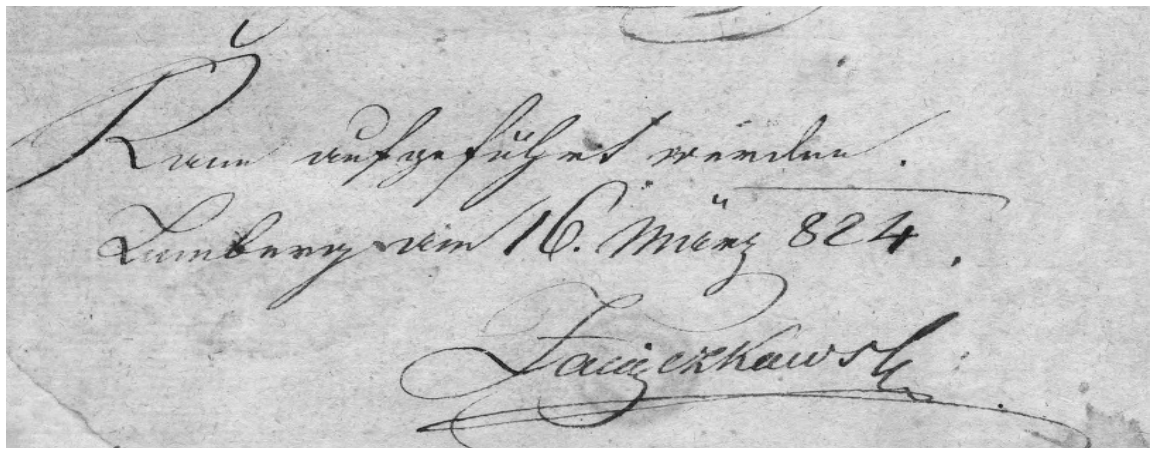

Szkoła starców, komedia, 1828

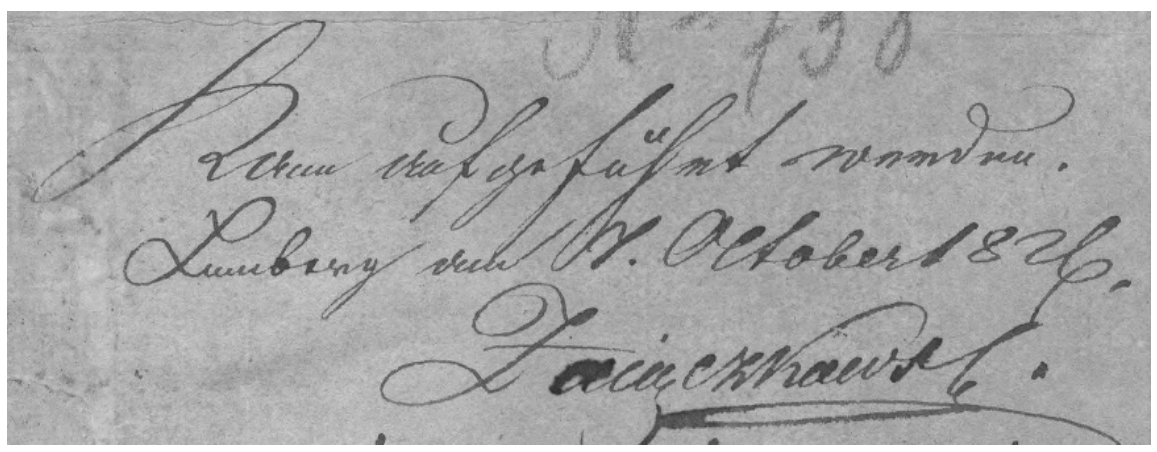


Tekst Saula zawiera liczne kreślenia cenzorskie. Podobnie jak w przypadku innych cenzorów, tak samo Zajączkowski nakazywał usuwanie zdań „w nadwyżce", nawet tam, gdzie teoretycznie frazy nie powinny dawać żadnych przypuszczeń do naruszania praw politycznych, moralnych i religijnych.

Zajączkowski eliminuje również zdania, które w kontekście ówczesnej epoki mogły posiadać konotacje rewolucyjne, nawiązujące w sposób mniej lub bardziej pośredni do obecnej sytuacji politycznej:

„Król i lud jego są w największym niebezpieczeństwie (...). Żelazo nieprzyjaciół wzniesione nad waszymi głowami” (Akt I, scena II)

„Ufaj wraz ze mną, że wielki Bóg Izraela wyrwie mię od śmierci, jeżelim nie zasłużył na nią" (Akt I, scena IV)

„Syn Abrahama gotowy jak ja przelać krew swoją na ołtarzu przez słowa i czyny swoje pokorne (...)" (Akt II, scena III)

„Nie wspiera On [Bóg] tych, którzy gardza Jego pomoca, ale nigdy nie umknął prawicy wzywającemu i ufającemu dobroci Jego" (Akt III, scena IV)

Wielokrotne odsyłanie tekstów do poprawek, nieustanna pokora i uniżoność, jakie trzeba było okazywać urzędnikom oraz narastające długi związane z opóźnieniem wystawiania sztuk niezaprzeczalnie utrudniały funkcjonowanie teatru we Lwowie. Nie powinno zatem dziwić, że ówczesny antreprener Kamiński miewał chwile poczucia niemożności zapanowania nad instytucją:

Wiadoma jest (...) cenzura policji lwowskiej, wiążąca usta i tłumiąca uczucia Polaków, łatwo więc pojmiesz, jak wielkie zawody ma Pan Kamiński w doprowadzeniu sceny polskiej do tej doskonałości, jaką jej jego geniusz i pilność nadać pragna $a^{19}$.

Austria, uznająca Galicję za kraj podbity, dążyła do jej zupełnego zniszczenia i wyginięcia w niej wszystkiego, co narodowe. Dlatego właśnie cenzura tak pilnie śledziła każda, choćby najmniejszą stronicę tekstu, na której mogło znaleźć się nawoływanie do walki i niezacierania pamięci o ojczyźnie. Jak opowiada pamiętnikarz tamtego okresu, Zygmunt Kaczkowski:

${ }^{19}$ Cyt. za B. Lasocka, op. cit., s. 53. Przytoczony fragment pochodzi z dokumentu z Archiwum Ministerstwa Spraw Wewnętrznych w Wiedniu. 
Zaprowadzono cenzurę, która nie dopuszczała książek, subwencjonowano pisemka niemieckie (...). Sprowadzano Niemców do kraju, a ci Niemcy nas nienawidzili i robili, co mogli, aby kraj opanować i na niemiecką prowincję przekształcić22.

${ }^{22}$ Z. Kaczkowski, Mój pamietnik z. lat 1833-1843, Lwów 1899, s. 31. 



\section{ZASADY OPRACOWANIA EDYTORSKIEGO}

Przedłożone tu zasady postępowania modernizacyjnego opracowano na podstawie zasad przyjętych w wydaniach: A. S. Naruszewicz, Poezje zebrane, wyd. B. Wolska, t. 2, Warszawa 2009, s. 180-186. Uwzględniono również cechy indywidualne języka autora edytowanych utworów, jako że teksty te powstały na przełomie XVIII/XIX wieku.

W niniejszym wydaniu utworu Wojciecha Bogusławskiego uwzględniono w pewnym stopniu zasady współcześnie obowiązującej interpunkcji logiczno-składniowej. Jednocześnie, przestrzegając płynność wypowiedzi w mowie wiązanej i jej specyficzną konstrukcję retoryczną, uszanowano interpunkcję retoryczno-intonacyjna, zacierana przez obecny system przestankowania. Tak więc np. w niektórych przypadkach osłabiano pauzy, zastępując średnik przecinkiem, w innych wzmacniano, wstawiając w miejsce przecinka średnik. Dwukropek poprzedzający bezpośrednie przytoczenie wypowiedzi został zastapiony na przecinek. Zważając na przeznaczenie utworów dramatycznych do realizacji scenicznej, pozostawiono występujące w podstawie wydania myślniki oznaczające silniejszą pauzę. Inne oznaczenia interpunkcyjne, stanowiące dla aktorów wskazówki do zawieszenia głosu bądź zmiany jego tonu („,...”, ,...”, ,,..” itd.) ujednolicono zgodnie ze współcześnie obowiązującymi zasadami interpunkcji.

Zmieniono w stosunku do pierwodruku zakres stosowania wielkich liter, ograniczając go. Majuskuły używano najczęściej przypadku wyrazów określających Boga wprost lub za pomoca peryfraz, np. Najwyższy, Prz̨edwieczny. Pozostawiono wielką literę w zwrotach grzecznościowych typu Waćpanowie, Wasżmości Panowie.

Zmodernizowano pisownię łączną i rozdzielną. Cząstki ruchome $-m,-\dot{z}$,

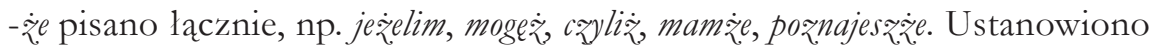
łączną pisownię wyrazów typu: $w$ krótce $\rightarrow$ wkrótce, $w$ pośród $\rightarrow$ wpośród. 
Pisownię głosek dźwięcznych i bezdźwięcznych modernizowano, np.: niebespieczeństwie $\rightarrow$ niebezpieczeństwie, meztwo $\rightarrow$ mestwo, mnóztwo $\rightarrow$ mnóstwo, blizka $\rightarrow$ bliskeq. Podobnie uwspółcześniono pisownię rzeczownika puhar $\rightarrow$ puchar.

Jasne $o$ zmodernizowano do pisowni dzisiejszej: bole $\rightarrow$ bóle, ktory $\rightarrow$ który, tłomaczy $\rightarrow$ ttumaczy.

Pisownię głosek i oraz y transkrybowano zgodnie z dzisiejszymi regułami, np. stilu $\rightarrow$ stylu.

Formy trajedia trajedii doprowadzono do postaci dzisiejszej.

W transkrypcji samogłosek nosowych przyjęto generalną zasadę modernizacji. Pozostawiono natomiast dawne, dość długo utrzymujące się formy: czasownika mieszka oraz rzeczownika pomieszanie.

Zredukowano podwójne spółgłoski (geminaty) w wyrazach obcego pochodzenia, np.: assyryjskim $\rightarrow$ asyryjskim, klassyczni $\rightarrow$ klasyczni.

Zachowano występujące w druku formy: nadgradza, podchlebca.

Wprowadzono cudzysłowy, zwiększając ich liczbę.

Poprawiono oczywiste błędy druku bez sygnalizowania tej ingerencji w tekście. Uzupełniano zatem dość częste braki znaków diakrytycznych oraz oczywiste błędne litery. Natomiast opuszczenia liter (czcionek) w wyrazach uzupełniano w tekście i aparacie krytycznym.

\section{CZASOWNIK}

Cząstki ruchome 1 i 2 os. l.poj. czasu przeszłego $(-m,-s)$ oraz partykuły -że,

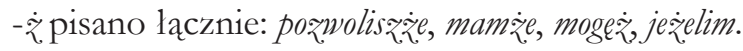

Formy czasownika: upojać, praysposobiać doprowadzono do postaci dzisiejszej.

Zmodernizowano formę 3. osoby liczby mnogiej czasownika: rozruca $\rightarrow$ rozrzuca.

Przyjęto zasadę modernizacji dla formy czasownika: pódź $\rightarrow$ pójdź:

\section{PRZYMIOTNIK}

Modernizowano l.mn. przymiotników -em, -emi do postaci -ym, -ymi: niewzruszonem $\rightarrow$ niewzruszonym, najwiekszem $\rightarrow$ najwiekszym, straszniejszemi $\rightarrow$ straszniejszymi.

Nie zachowano formy ws zyttkie, doprowadzając ją do postaci dzisiejszej. 


\section{PRZYIMEK}

Zachowano dawne formy oboczne przyimków: z zdradliwych, z zdrajcami.

\section{ZAIMEK}

Zachowano występujące oboczne formy zaimka mię $\mid$ mnie.

Pozostawiono końcówkę - e biernika l.poj. zaimków: twoje, swoje, nasze. Modernizowano końcówki l.mn. zaimków -em, -emi do postaci -ym, -ymi: moiem $\rightarrow$ moim, twoiemi $\rightarrow$ twoimi, waszemi $\rightarrow$ waszymi.

\section{RZECZOWNIK (DEKLINACJA)}

Utrzymano dawną formę w dopełniaczu l.poj. rzeczownika r.m: poranku (= poranka).

Ujednolicono pisownię końcówki -ow dopełniacza l.mn. rzeczownika r.m: bolów $\rightarrow$ bólów.

Zmodernizowano o bez pochylenia w końcówce dopełniacza l.mn. rzeczownika r.m.: nieprzejaciot $\rightarrow$ nieprayjaciót.

Zachowano końcówkę - $q$ w bierniku l.poj. rzeczowników r.ż. miękkotematowych: tragedia, jaskinia, pustyniq.

Pozostawiono końcówkę $-y$ w narzędniku l.mn. rzeczowników: widziadty (= widziadłami), rozkaazy (= rozkazami), dostojeństwy (= dostojeństwami), skrayydty (= skrzydłami).

Zmodernizowano dawną formę wyrazu letkości $\rightarrow$ lekekości.

\section{INNE FORMY RZECZOWNIKA}

Grupę spółgłoskową -źræ- zachowano zgodnie z pisownią druku: źrzódło. Zachowano formę: podchlebca.

Literę $x$ transkrybowano jako ks: xię̇yc $\rightarrow$ księzyc. 



\section{Wykaz znaków i skrótów przyjętych w edycji}

$<>$ — nawiasy kątowe w tekście utworu sygnalizują ingerencje wydawcy, zarówno emendacje, jak i koniektury.

[] - nawiasy kwadratowe sygnalizują pochodzace od wydawcy uzupełnienia o charakterze redakcyjnym, w tym także rozwiązania skrótów.

dat. — datowany

fr. - francuski

hebr. - hebrajski

in. - inaczej

$\mathrm{km}$ - kilometr

m.in. — między innymi

niem. - niemiecki

nr - numer

p.n.e - przed naszą era

pol. - połowa

por. - porównaj

prof. - profesor

przyp. - przypis

rkps - rękopis

s. - strona

sygn. - sygnatura

t. - tom

tzw. - tak zwany

wg — według

właśc. — właściwie

wyd. - wydanie

zob. - zobacz 


\section{SKRÓTY KSIĄG BIBLIJNYCH}

Rdz - Księga Rodzaju

Wj - Księga Wyjścia

Kpł - Księga Kapłańska

Lb - Księga Liczb

Sdz - Księga Sędziów

$1 \mathrm{Sm}-1$ Księga Samuela

2 Sm - 2 Ksiega Samuela

$1 \mathrm{Krl}$ - 1 Księga Królewska

2Krn - 2 Księga Kronik

PnP — Pieśń nad Pieśniami

Lm — Lamentacje 


\section{ALFIERI}

Wiktor Hrabia Alfieri, urodził się około połowy zeszłego wieku w Asti, mieście Piemontu ${ }^{1}$. Pierwsze nauki brał w rodzicielskim domu, gdzie czytanie nad wszystko dziejów ojczyzny swojej zagnieździło w duszy jego tę miłość wolności i republikanizmu, która później w pismach jego widzieć się dała; Asti bowiem w XII i XIV wieku wielkie miało znaczenie w rzędzie miast podzielonej naówczas na różne stronnictwa włoskiej krainy, i nakłoniło do przyjęcia republikanckiej konstytucji znaczną część Piemontu i Monferatu². Dalsze nauki brał Alfieri w wojskowej Akademii w Turynie, w których, jak naówczas, nie bardzo wyższego urodzenia młodzież celowała. Ten sam los był Alfierego. Mało co więcej nabywszy umiejętności, opuścił szkoły i udał się do wojska. Wkrótce, sprzykrzywszy sobie nieczynność prowincjonalnego regimentu ${ }^{3}$, który raz tylko w rok zbierał się na majowe ćwiczenia, wyszedł z służby, a od dawna chęcią widzenia obcych krajów zajęty, zwiedził Francją, Niemcy, Holandią i Anglią. Kilkanaście dzieł francuskich, przeczytanych w podróży, poznanie odmiennych rządów, zwyczajów i zdań obcych narodów, podały miłości własnej Alfierego mniemanie, że był uczonym człowiekiem. Powróciwszy do ojczyzny, tęschnotą domowego życia dręczony myślał, jakim by sposobem mógł odwrócić codzienne nudy. Zapał młodości podał mu pióro do ręki, a żądza sławy zrodziła w nim skłonność do pisania dzieł dramatycznych.

1 Piemont — region administracyjny w północno-zachodnich Włoszech; graniczy z Francją i Szwajcaria.

${ }^{2}$ Monferat — właśc. Monferatto, region Piemontu w północnych Włoszech.

3 regiment — pułk. 
Najpierwszym jego w tym rodzaju dziełem była tragedia: Kleopatra ${ }^{4}$, która, jak to sam w liście pisanym do przyjaciela i krytyka swojego Calsabigi ${ }^{5}$ wyznaje, była tym, czym, od młodzika wygórowane o sobie rozumienie mającego napisana, być koniecznie musiała potworem. Wystawiona po dwa razy w 1775 na teatrze w Turynie, nie tylko (słowa są jego) słuchana, przyjęta, ale nawet, ku wiecznej publiczności i autora hańbie, oklaskami uwieńczona została!

To pierwsze i tak pomyślne literackiej pracy jego przyjęcie, może by w nim było na zawsze chęć prawdziwej doskonałości stłumiło, gdyby uwagi oświeconych jego przyjaciół nie wskazały mu były nikczemności pozyskanego tryumfu. Poznał się na niej Alfieri, a chcąc i pobłażające publiczności o sobie zdanie w czasie usprawiedliwić $\mathrm{i}$ w własnym swoim przekonaniu stać się onego godnym, cały poświęcił się naukom.

Nie łatwym było uskutecznienie tego chwalebnego zamysłu młodzieńcowi, który bardzo mierne posiadając umiejętności, wszystkiego, niejako na nowo, uczyć się musiał. Ale Alfieri dotrzymał danego sobie słowa; a ch<c $>$ ąc zacząć od poznania własnego swojego języka, udał się do Toskanii ${ }^{6}$, gdzie najczyściejszym dialektem mówią, i tam lat kilka, a najdłużej w Sienie ${ }^{7}$, mieszkał.

Najpierwszym jego staraniem było poznanie ojczystych autorów w każdym rodzaju. Filangieri ${ }^{8}$, Bertola $^{9}$, Cesarotti ${ }^{10}$, i inni pisarze w prozie; Parini ${ }^{11}$,

${ }^{4}$ Kleopatra - właśc. Antoniusz i Kleopatra, tragedia; wystawiona w 1775 roku.

${ }^{5}$ Calsabigi - właśc. Ranieri de 'Calzabigi; ur. 23 XII 1714, zm. VII 1795, poeta włoski, librecista. Współpracował z kompozytorem Christophem Willibaldem Gluckiem w jego „reformie” opery.

${ }^{6}$ Toskania — region administracyjny w środkowych Włoszech, jej stolica jest Florencja.

7 Siena - gmina w Toskanii.

${ }^{8}$ Filangieri - właśc. Gaetano Filangeri, ur. 1753, zm. 1788, uczony, prawnik, minister i reformator w Królestwie Neapolu. W dziele La scienza della legislazione przedstawil ideał ustawodawstwa.

${ }^{9}$ Bertola — właśc. Bertoli D. Jerzy.

${ }^{10}$ Cesarotti - właśc. Melchiore Cesarotti, ur. 1730, zm. 1808, włoski poeta, literat, tłumacz Iliady Homera.

11 Parini - właśc. Giuseppe Parini, ur. 1729, zm. 1799, poeta, tłumacz, librecista, propagator neoklasycyzmu. 
Monti $^{12}$, Colpani ${ }^{13}$, a nad wszystkich Tasso ${ }^{14}$ i Dantes ${ }^{15}$ w poezji, służyli mu za wzory gustu, wyniosłych myśli i czystości języka. Autorowie klasyczni, Wirgilii $^{16}$, Horacy $^{17}$, Seneka $^{18}$ i ulubiony od niego Tacyt ${ }^{19}$, męską dawnych wieków

${ }^{12}$ Monti — właśc. Vincenzo Monti, ur. 1754, zm. 1828, włoski poeta, dramatopisarz, tłumacz Iliady Homera.

${ }^{13}$ Colpani — właśc. Giuseppe Colpani, ur. 1738, zm. 1822, włoski poeta.

${ }^{14}$ Tasso — Torquato, ur. 11 III 1544 w Sorrento, zm. 25 IV 1595 w Rzymie. Włoski poeta, związany z dworami w Urbino i Pesaro. Wczesna twórczość utrzymana w atmosferze kulturowego i społecznego niepokoju lat potrydenckich. Najwybitniejsze dzieło to Jerozolima nyzzolona, poemat epicki w dwudziestu pieśniach. W ostatnich latach życia prześladowany i osądzany o herezję. Jego twórczość wywarła duży wpływ na późniejszych twórców, gł. w epoce Romantyzmu, np. Byrona czy Adama Mickiewicza.

${ }^{15}$ Dantes — właśc. Dante Alighieri, ur. V 1265 we Florencji, zm. IX 1321 w Rawennie. Włoski poeta, filozof, polityk. Zaangażowany w walkę stronnictw, która dzieliła Florencję, walczył pod Campaldino (1289) i sprawował urząd priora. Klęska Białych, do których należał, uniemożliwiła mu dalsze życie we Florencji, stąd rozpoczął tułaczkę po kraju. Ostatecznie schronił się na dworze w Rawennie, gdzie zamieszkał do końca swoich dni. Ok. 100 wierszy lirycznych i okolicznościowych zebrano po jego śmierci w tomie Canzoniere. Część z nich Dante wcielił do Nowego s̀ycia, pamiętnika poetyckiego, poświęconego głównie uczuciom do B. Portani. Ta wysublimowana miłość znalazła również wyraz w największym dziele - Boskiej komedii, poemacie uchodzącym za intelektualno-artystyczną syntezę kultury i myśli filozoficznej średniowiecza, nasycona realiami społeczno-politycznymi.

${ }^{16}$ Wergiliusz - ur. 15 X 70 w Andes, zm. 21 IX 19 p.n.e. Poeta, największy epik rzymski, autor Eneidy, narodowego eposu Rzymian. Inne dzieła: Bukoliki, Georgiki.

${ }^{17}$ Horacy - ur. 8 XII 65 w Wenuzji, zm. 27 XI 8 p.n.e. Jeden z największych liryków, działający w okresie najwspanialszego rozkwitu literatury rzymskiej za czasów Oktawiana Augusta. Autor Listu do Pižnów, uznawanego za teoretyczny wykład twórczości poetyckiej aż po pocz. XIX w. Jest także twórcą Epod, Satyr, Pieśni.

${ }^{18}$ Seneka - ur. ok. 3 r., zm. w 65 r., rzymski retor, pisarz, poeta i filozof, przedstawiciel późnego stoicyzmu. Swoje rozważania filologiczne koncentrował na zgodnym z ideałami stoickimi rozwiązywaniu zagadnień etycznych i praktyczno-życiowych; pisał też prace dot. zagadnień z dziedziny astronomii, geografii, rozpatrywanych ze stoickiego punktu widzenia. Zachowało się kilkanaście epigramów i 9 tragedii (m. in. Fedra, Edyp, Agamemnon, Trojanker).

19 Tacyt — ur. ok. 55, zm. ok. 120, najwybitniejszy historyk rzymski, obrońca sądowy, urzędnik. Pisał historię z wyraźnym celem moralizatorskim; piętnował okres przemocy za panowania Dioklecjana, doskonale charakteryzowal przedstawiane postaci, dramatyzował wypadki historyczne. Do najważniejszych jego dzieł należą: Dřieje, Roczniki, Żywot Agrykoli. 
wymową wzmocnili styl jego. Ale zamknięty mu był jeszcze wstęp do źrzódła innych starożytnych piękności, przez nieumiejętność greckiego języka. Sofokles $^{20}$, Eurypides ${ }^{21}$, owi pierwsi prawodawcy dawnej tragedii, byli dla niego obcymi. Pragnął jeszcze i angielskich autorów poznać piękności, ale ta sama przyczyna stawała mu na przeszkodzie; a nauczenie się tych języków, ile już w jego wieku, zdawało mu się być prawie niepodobnym. Szczęśliwy przypadek ułatwił niespodziewanie te wszystkie trudności.

Potrzeba było Alfieremu udać się na krótki czas do Florencji. Tam poznał się z hrabiną Albani ${ }^{22}$, żoną Karola Edwarda ${ }^{23}$, pretendenta angielskiego ${ }^{24}$. Widzieć tę, dla wdzięków i wysokich umiejętności powszechnie poważaną piękność i natychmiast na zawsze ja pokochać, było dla Alfierego najszczęśliwszym zdarzeniem. Odtąd chęć podobania się tak godnemu przedmiotowi swojej miłości, była dla niego podnietą do najtrudniejszych mozołów, osłoda najprzykrzejszej pracy. Grecki i angielski języki już mu się nie zdawały zbyt trudną nauką i w przeciagu lat trzech posiadał obadwa tak doskonale, że mu już wszystkie starożytnych poetów dzieła znajome były. Przez siedmiu lat przeciag

${ }^{20}$ Sofokles - ur. 496 w Kolonos, zm. 406 p.n.e. w Atenach; tragediopisarz, brał czynny udział w życiu politycznym Aten jako skarbnik Związku Ateńskiego, strateg, członek komisji do reformy ustroju Aten; był dowódcą wojskowym, kapłanem. Napisał około 120 sztuk, zachowało się 7 całych tragedii, m.in.: Ajas, Antygona, Trachiniki, Król Edyp.

${ }^{21}$ Eurypides - ur. 480 p.n.e., zm. 406 p.n.e. w Antenach; jeden z najwybitniejszych dramaturgów starożytnej Grecji. Z ok. 90 napisanych przez niego sztuk teatralnych zachowało się 17, m.in. Medea, Hipolit, Blagalnice, Elektra, Orestes.

${ }^{22}$ Hrabina Albani - właśc. Ludwika Stolberg-Gedern, ur. 20 IX 1752, zm. 29 I 1821; żona Karola Edwarda Stuarta. W 1780 zostawiła męża, tłumacząc, że ten znęcał się nad nią psychicznie. Opinia publiczna uwierzyła Ludwice, mimo że od dłuższego czasu żyła ona w związku z Vittorio Alfierim. Małżonkowie nie rozwiedli się, lecz pozostali w separacji. Po śmierci Karola Edwarda, Ludwika i Alfieri osiedli we Florencji.

${ }^{23}$ Karol Edward - właśc. Karol Edward Stuart, ur. 31 XII 1720, zm. 31 I 1788, syn Jakuba III Stuarta i Klementyny Sobieskiej, wnuczki Jana III. Młodszy pretendent do tronu angielskiego; dażąc do władzy wywołał w 1745 powstanie jakobitów w Szkocji; po początkowych sukcesach poniósł klęskę pod Culloden Moor i schronił się we Francji. W 1772, w wieku pięćdziesięciu dwóch lat poślubił dwudziestoletnią księżniczkę Ludwikę Stolberg-Gedern. Para zamieszkała w Rzymie, a w 1774 przeniosła się do Florencji; wtedy Karol Edward zaczął używać tytułu hrabiego Albany.

${ }^{24}$ pretendent — ten, kto ubiega się o coś, rości sobie pretensje do czegoś. 
pracował Alfieri nad wydoskonaleniem swojego umysłu, z którego wkrótce wydoskonalenie tragicznej sztuki wziąć miało początek. Niespodziewany zgon męża tej, którą on uwielbiał, podając mu nadzieję wzajemności, zapalił w nim jeszcze bardziej żądzę wysokiej sławy, która by go wystawiła godniejszym zbliżenia się do ulubionej osoby, a z którą później aż do końca swojego życia ścisłą połączony przyjaźnią, wszelakie szczęścia i przeciwności dzielił wypadki.

Za najskuteczniejszy w tej mierze sposób obrawszy wsławienie się przez wysoką naukę, ułożył sobie pozyskać imię najpierwszego w swej ojczyźnie tragicznego autora; przez utworzenie nowego rodzaju tragedii, która by najwięcej do natury zbliżona, najbardziej przeto do dzieł greckich podobną była. Tak swój zamiar w liście do Calsabigi tłomaczy:

Tragedią w 5 ciu aktach pełnych przedmiotu, który przedstawia; zawsze jednę w swojej osnowie; przez same działające osoby wysłowiona; bez żadnych powierników i niepotrzebnych świadków; tragedią ciągłą bez żadnej przerwy; prędką, ile namiętności osób przyśpieszyć onę pozwolą prosta, ile przepisy sztuki dopuszcza; okropna, ile natura znieść potrafi; ognista, ile mi ją własne czucie ożywić pomoże; taką tragedią, jeżeli nie zdołałem, przynajmniej chciałem utworzyć.

Takie prawidła nowego rodzaju tragedii utworzywszy sobie sam Alfieri, wziął się na koniec do spełnienia swego zamiaru. Po siedmiu latach przerwy od wystawienia pierwszej tragedii Kleopatry, którą, jak pisze, spalił natychmiast; napisał druga, niemal najlepszą z dzieł jego: Antygone, która w roku 1782, pierwszy raz w Rzymie wystawiona była. Wkrótce po niej: Fillippa, Polinika i Wirginia; w 1784: Agamemnona, Orestesa, Rosmunde, a w 1785 Oktawia, Timoleona i Merope. Te dziesięć sztuk wydrukowane razem w Sienie, wydał na widok publiczny.

Jak wszystkie na świecie nowo zjawiające się rzeczy, do różnych o sobie zdań daja powody; tak i nowy rodzaj tragedii Alfierego, razem pochwał i przygan stał się przedmiotem. Upatrywali w nich dziwactwo ci, którym dawny sposób pisania zdawał się być lepszym. Zazdrośni chwały autora ganili je i odrzucali; zapaleni jego czciciele ogłaszali w nim człowieka mającego okryć chwałą literaturę włoska, a bezstronni przyjaciele i Alfierego, i nauk, wytykali rzetelne uchybienia i wady. Przyjął ich sprawiedliwe uwagi Alfieri, złagodził twardość stylu, odmie- 
nił wiele przykrych wyrazów, wiele zbył ${ }^{25}$ wygórowanych myśli, a tak poprawiwszy pierwsze dziesięć tragedii, napisał jeszcze przez resztę życia dziewięć innych, które sa: Maria Stuard, Spisek Pazzón, Don Garcia, Saul, Agid, Sofoniz̧a, Brutus pierws ży, Myrra i Brutus drugi; na którym kończąc tragiczne swoje prace, użala się na słabość podeszłego już swego wieku, następującymi wierszami:

To mnie już zdjąć przymusza (jeśli w nim chodziłem)

Włoskiego z nogi mojej obuwie koturna,

I przysiąc sobie nigdy nie wdziewać go więcej(a).

Czytając wymienione Alfierego dzieła, poznać można, jak praktycznie starał się dowieść teorii przepisów, które nadał nowej tragedii. Wszystkie jego sztuki są krótkie, zwięzłe, jedno tylko zdarzenie przedstawiające. Żadne inne uboczne intrygi nie przerywają ich ciagu, żadne epizodyczne osoby nie odwracają uwagi od głównych. Wszystko się w nich około jednego punktu obraca. Wprowadzenia rzeczy dzieją się w samej już akcji, bez żadnych opowiadań nudzących. Charaktery osób zawsze naturalne, rozwijają się stopniami. Wszelkie namiętności coraz silniej działają; im bliżej końca tym więcej mocy, więcej ognia nabiera rzecz cała i wszystkie katastrofy kończa się przed oczyma patrzących. Wymowa jego jest zwięzłą, zawsze wiekom i osobom, które przedstawia właściwa; w kilku wierszach wyraża czasem więcej, niżeli inne sztuki w całkowitych scenach. Ożywił on wiele wyrazów, wiele sposobów mówienia w języku jego już zapomnianych, a które przypominają jędrność pierwiastkowej łacińsko-włoskiej wymowy. Myśli jego energiczne, śmiałe, wysłowione są w sposobie wcale nowym; chciał on bowiem ukształcić oddzielny niejako język, graniczący pomiędzy tragedią i wszelkimi innymi poetycznymi tworami. Słowem, zostawił wzory, których naśladowanie może z czasem sztukę tragiczną do najwyższej podnieść doskonałości.

Najpiękniejszymi z tragedii jego sa: Antygona, Orestes, Agamemnon, Saul, Sofonisba, Meropa. Z późniejszych dziejów napisane: Spisek Pazzón, Don Gracya, Rosmunda,

\footnotetext{
(a) Senno m' inpon, ch'io quii (Se il pur calzai)

Dal piè mi scinga i'Italo coturno,

E giuri a me di nol piu assumer mai (przyp. aut.).

${ }^{25}$ zbyć - tu: usunąć.
} 
Filp II, Maria Stuartd dają widzieć zawsze w nim gorejącą nienawiść despotyzmu. Brutus, Timoleon, Wirginia wzory patriotyzmu, maluja prawdziwie rzymska miłość ojczystej wolności. Chciał jeszcze Alfieri i w innych rodzajach dramatyzmu doświadczyć zdolności swojej. Napisał sześć komedii i jedna, tak od niego nazwana, tramelogedią ${ }^{26}$. Wiek podeszły, umysł około smutnych zawsze pracujący przedmiotów, pozbawily go potrzebnej wesołości i tej lekkości stylu, na jakich dobroć dzieł komicznych zależy. Wszystkie te płody nie sa godne swojego autora. Tramelogedia Abel jest mięszaniną tragedii z opera, w której przyjemne liryczne własności z wspaniałą prostotą tragedii połączone mogłyby były utworzyć nowy rodzaj tragicznej opery, gdyby był Alfieri poświęcił zdolność swoję dalszemu onej wydoskonaleniu. Przełożył także z greckiego kilka sztuk: Eschyla ${ }^{27}$, Sofoklesa ${ }^{28}$, Euripida $^{29}$, i Aristofana ${ }^{30}$. Oprócz dzieł dramatycznych, pisał jeszcze Alfieri wiele innych w różnym rodzaju, w których się doskonale polityczne zdania jego maluja, ale przedsięwzięcie moje pisania o samych tylko dramatycznych dziełach autorów, nie pozwala mi w roztrząsanie owych się wdawać.

Tragedia Saul, była na scenie polskiej pierwsza, która nowego tego autora dała poznać naszej publiczności. Później wystawione Filip II i Wirginia niemniej podchlebne pozyskały przyjęcie. Należy życzyć, aby tłumacze nasi dali dokładniej poznać piękności jego poezji.

${ }^{26}$ tramelogedia — gatunek dramatu muzycznego pośredni między tragedią i opera, zwracający publiczność do opery i przygotowujący ich do prawdziwej tragedii.

${ }^{27}$ Eschyl — właśc. Ajschylos, ur. 525 w Eleusis, zm. 456 p.n.e. na Sycylii; twórca tragedii greckiej; wzbogacił strukturę utworu prologiem, zindywidualizował język postaci dramatu, zastosowal nowe środki wyrazu artystycznego. Z 70 tragedii i 20 dramatów satyrowych zachowało się w całości 7 tragedii: Blagalnice, Persowie, Siedmiu præeciw Tebom, Prometeusz skowany, Oresteja (Agamemnon, Ofiarnice, Eumenidy). W czasie najazdu Persów walczył pod Maratonem (490), Salaminą (480) i pod Platejami (481).

28 Sofokles - zob. przyp. 20.

${ }^{29}$ Euripid - zob. przyp. 21.

${ }^{30}$ Aristofan - właśc. Arystofanes, ur. ok. 446, zm. w Atenach ok. 386 p.n.e., komediopisarz grecki, główny przedstawiciel starej komedii attyckiej. Ostrze swojej satyry zwracał przeciwko współczesnym mu osobistościom życia politycznego i kulturalnego. Występował gwałtownie przeciw zaborczym tendencjom Aten i współcześnie prowadzonej, wyniszczającej kraj wojnie peloponeskiej (431-404 p.n.e.). Napisał m.in.: Rycersy (424 p.n.e.), Chmury (423 p.n.e.), Lisystrata (411 p.n.e.). 
Cią̧łe prace, różnego rodzaju umartwienia z powodu utraty majątku i niebezpieczeństw, na jakie w czasie zaburzeń włoskich był wystawionym, skróciły życie Alfierego. Umarł 8 października 1803 roku. Wspaniały, marmurowy nagrobek w kościele Ś<więte>go krzyża w Florencji, pomiędzy pomnikami Machiawela $^{31}$ i Michała Bonarotti ${ }^{32}$, kosztem hrabiny Albani, przez Canovę $e^{33}$ zrobiony, pokrywa zwłoki jego; a tak, sławnego w wieku naszym snycerza dłuto, uwieczniło pamiątkę równie sławnego poety.

${ }^{31}$ Machiawel — właśc. Niccolò Machiavelli, ur. 1469, zm. 1527, pisarz polityczny i społeczny odrodzenia, dyplomata i historyk florencki. Sekretarz Kancelarii Dziesięciu republiki florenckiej. Do jego najważniejszych prac należą: Dialoghi dell' arte della guerra (1521), Mandragora (1521), Ksiqże (1532).

${ }^{32}$ Michat Bonarotti - Michelangelo Buonarroti, ur. 1568, zm. 1642, pisarz włoski, bratanek Michała Anioła, gromadził regionalne słownictwo Toskanii, które później wykorzystywał w swoich utworach: Tancia (1612), wiejskiej komedii o miłości oraz komedii widowiskowej La Fiera (1618).

${ }^{33}$ Canova - właśc. Antonio Canova (1757-1822), rzeźbiarz i architekt włoski. 


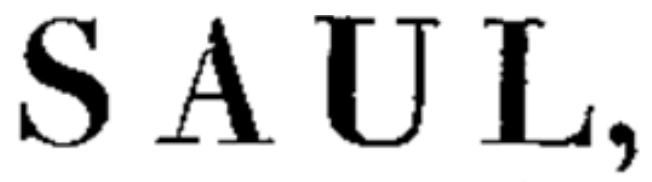

'T R A G E D Y A. 



\section{SAUL}

\section{TRAGEDIA}




\section{Osoby}

SAUL

DAWID

MICHOLA

JONATHAS

ACHIMELECK

ABNER 


\section{AKT I \\ SCENA I}

\section{DAWID}

sam

Wszechmocny Boże! Pozwoliszże nareszcie, ażebym zakończył tę haniebną

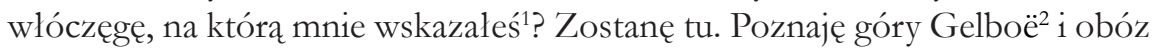
Izraelitów, wystawiony naprzeciw Filistynom bezbożnym. Obym mógł dziś zginą<ć> pod żelazem nieprzyjaciół! Ale ach!... Z ręki to raczej Saula powinienem oczekiwać śmierci!... Okrutny i niewdzięczny Saulu! Czemuż, bez dania mu odpoczynku, z jaskini do jaskini ścigasz tego, który bił się za ciebie? - Wszakże Dawid był dawniej jedyną twoją podpora, pokładałeś w nim całe zaufanie; wyniosłeś go do szczytu godności; wybrałeś go za męża twej córce... I ażeby pozyskał ten dar najdroższy, wymagałeś od niego stu głów filistyńskich ${ }^{3}$ a on ci ich dwakroć tyle złożył pod nogi. - Ale poznaję ja to, że Saul od dawnego już czasu nie jest przy zmysłach. Bóg opuścił go i oddał duchowi ciemnoty... Nieszczęśliwi! Czymże jesteśmy, kiedy nam Bóg umyka swojej opieki! - O, nocy! Spiesz ustapić dniowi; będzie on świadkiem wielkiego przedsięwzięcia! Gelboë, ty słynąć będziesz w następnych wiekach; powiedzą one: Dawid sam się oddał w ręce okrutnego Saula!... Wychodź, Izraelu, z twoich spokojnych namiotów... A ty Saulu, pokaż się; obaczysz dziś, jeżeli zapomniałem sztuki wojennej. - Wystąp z twojego obozu, Filistynie bezbożny, wystap, a poznasz wkrótce odwagę i żelazo Dawida.

${ }^{1}$ wskazać - tu: skazać.

${ }^{2}$ Gelbö̈ — hebr. Gilbōa; pasmo wzgórz w Samarii. Filistyni pokonali tu Izraelitów pod wodzą króla Saula (1 Sm 30,1-3). W walce tej zabronił Dawidowi walczyć książę Akisz, syn Maoka, króla Gat (1 Sm 29,6-11). Na wzgórzu Gilbōa odbyła się również bitwa, w czasie której Saul wraz ze swoimi synami poniósł śmierć (1 Sm 31,1-4).

${ }^{3}$ Filistyni - hebr. pelistim ('rozproszeni'); lud niesemicki, pochodzący prawdopodobnie z Kaftor, którym jest najprawdopodobniej Kreta. W XII w. p.n.e. wraz z innymi „ludami morza” stanowili część wielkiej fali migracyjnej, która doszła aż do granic Egiptu. W 1194 p.n.e. zostali rozbici przez wojska egipskie Ramzesa III, wskutek czego ulegli rozproszeniu. Część z nich osiadła w kraju Kanaan. Swoimi najazdami niepokoili sąsiadujący z nimi Izrael w czasach sędziów i Saula; dopiero król Dawid zdołał ich pokonać (2 Sm 5,17-25). Utrzymali się jednak na wybrzeżu. Od III w. p.n.e. ulegali szybkiej hellenizacji.

4 umykać - tu: ujmować, umniejszać, odtrącać. 


\section{SCENA II \\ DAWID, JONATHAS \\ JONATHAS}

Cóż to za szmer obija się o moje uszy? Słyszę jakiś głos znajomy sercu mojemu.

\section{DAWID}

Któż się zbliża? Czemuż jeszcze słońce nie wstaje? Nie chciałbym się tu jak zbieg pokazać.

\section{JONATHAS}

Kto ty jesteś? Co robisz tak blisko królewskiego namiotu? Odpowiedz?...

\section{DAWID}

Jestem pacholę wojny. Niech żyje Izrael! Znają mnie Filistyni.

\section{JONATHAS}

Co słyszę? Ach! Sam tylko Dawid tak mi odpowiadać może.

\section{DAWID}

Jonathas!

$$
\text { JONATHAS }
$$

Dawid!... Bracie mój!...

$$
\text { DAWID }
$$

O szczęśliwości! Jestem w twoich objęciach.

$$
\text { JONATHAS }
$$

Nie jestże to snem!... Ty, w Gelboë! Nie obawiaszże się ojca mojego? Drżę o ciebie.

\section{DAWID}

Cóż mam czynić? Tysiąc razy widziałem z bliska i zawstydziłem śmierć na polu bitwy. Uciekałem przed niesłusznym gniewem twojego ojca, ale dla żołnierza bojaźń i ucieczka straszniejszymi są nad śmierć samą! Odtąd nie chcę ani uciekać, ani bać się. Król i lud jego są w największym niebezpieczeństwie, a Dawid miałby wpośród lasów szukać schronienia? Ja miałbym ochraniać życie, kiedy 
żelazo nieprzyjaciół wyniesione nad waszymi głowami? Przychodzę umrzeć, ale chcę umrzeć na pobojowisku, wpośród oręży ${ }^{5}$, służąc mojej ojczyźnie. $\mathrm{Na}$ koniec przychodzę umrzeć za tego Saula, który mnie na śmierć wskazał ${ }^{6}$.

\section{JONATHAS}

O, cnoto godna Dawida! Ty jesteś wybrańcem Boga; on to tchnie w ciebie te wspaniałe zdania; anioł jego czuwa nad tobą i towarzyszy twym krokom. — Z tym wszystkim, jakże cię stawić przed królem? On rozumie albo może udaje, że rozumie cię być między nieprzyjacielskimi rotami ${ }^{7}$, on cię udaje $\mathrm{e}^{8} \mathrm{za}$ zdrajcę, za buntownika. -

\section{DAWID}

O! Aż nadto prawda, że chciał mnie przymusić do szukania przytułku9 między Filistynami. Ale nie znał mnie dobrze. Kiedy Filistyni podnieśli oręż przeciwko niemu, ja mojego nie złożę wprzód, póki ci zdrajcy wytępieni nie będa. Niechaj potem Saul da mi nagrodę, którą mi już przeznaczył: nienawiść swoję i śmierć.

\section{JONATHAS}

Nieszczęśliwy ojciec! Oszukany jest. Bojá́liwy i podły Abner, zdradliwy jego przyjaciel, nie odstępuje go na chwilę. Duch ciemności, który opanował Saula, kilka czasem chwil zostawia mu spoczynku, ale szpiegi Abnera nieustannie czuwaja około $^{10}$ niego. Jego samego król słucha, jego samego kocha; a sztuczny podchlebca ${ }^{11}$ umie wystawiać $^{12} \mathrm{mu}$ niebezpiecznymi te cnoty, których sam nie ma. Na próżno usiłujemy, ja i twoja małżonka...

\section{DAWID}

Małżonka moja! O, słodkie nazwisko! Gdzież jest wierna moja Michola? Kochaż mnie jeszcze mimo nienawiści twojego ojca?

\footnotetext{
${ }^{5}$ oreż - broń, uzbrojenie.

${ }^{6}$ wskazać - tu: skazać.

${ }^{7}$ rota — tu: oddział wojskowy.

${ }^{8}$ udawać - tu: uznawać, poczytywać, traktować.

${ }^{9}$ praytułek — tu: schronienie, kryjówka, utrzymanie.

10 około — tu: wokół, naokoło, dookoła.

${ }^{11}$ podchlebca — właśc.: pochlebca.

12 wystawiać — tu: ukazywać, uwidoczniać, przedłożyć.
} 


\section{JONATHAS}

Czy-li cię kocha?... Jest tu w obozie.

\section{DAWID}

Zobaczę ją! O, szczęśliwości! Ale dlaczegoż jest tu w obozie?

\section{JONATHAS}

Ojciec uczuł litość nad nią. Nie chciał ją zostawić w pałacu samotna, wystawioną na wszelkie boleści. Chociaż sama jest zawsze smutna, jednak czasem przynosi mu pociechę. Ach, Dawidzie, odtąd jak od nas daleko jesteś, dom nasz stał się domem cierpienia i płaczu.

\section{DAWID}

Ukochana małżonko! Przyjemne twoje spojrzenie odbierze mi pamięć przeszłych bólów moich i przeczucie tych, które mnie czekają.

\section{JONATHAS}

O, gdybyś mógł ją był widzieć! — Jak tylko porwano cię od niej, zrzuciła natychmiast wszystkie ozdoby. Popiół okrył roztargane jej włosy, bladość osiadła na licach łzami zalanych, a boleść głęboka i niema ogarnęła jej serce! W dzień twojego oddalenia sto razy upadła do nóg ojca i ze łkaniem wołała do niego: „Oddaj mi Dawida, wszak ty mi go dałeś”. Szarpała swoje odzienie, oblewała łzami ręce ojca, który razem z nią płakał. - Ale Abner rozkazał ja porwać od nóg Saula prawie na pół umarła.. -

\section{DAWID}

O, boleści! Cóż mi to powiadasz!

\section{JONATHAS}

Dałby to Bóg, ażeby ta okropna powieść nie była prawdą! - Pokój, sława i męstwo naszego ludu zniknęły wraz z tobą! Serca Izraelitów śmiertelnym są zamroczone letargiem ${ }^{13}$ ! Filistyni, którzy na widok twych znaków stawali przed nami jak bojaźliwe dzieci, zdają się nam ogromnymi olbrzymami odtąd, jak być wodzem naszym przestałeś. Otoczeni w tych górach, zapominając o sobie samych, znosimy cierpliwie ich pogróżki, ich naigrawania i wzgardę! Tracąc Dawida, Izrael utracił swój oręż, swoję odwagę! Ja sam, który dawniej

${ }^{13}$ letarg — chorobowy stan senności, który cechuje bezwładność i brak reakcji na bodźce. 
idąc twoimi ślady, niejaka zyskałem chwałę, dziś czuję, że ramię moje zaledwie unieść może ciężar oręża! Odtąd, jak się oddaliłeś ode mnie, jak wiem, na jakie wystawiony jesteś niebezpieczeństwa, skazany na życie nieszczęsne, zdaje mi się, że nie walczę więcej ani za króla, ani za ojca, ani za rodzeństwo moje. Ach! Ty mi jesteś milszym nad króla, nad ojca i nad całe rodzeństwo.

\section{DAWID}

Kochasz mnie więcej, niżeli zasłużyłem — ty jesteś kochanym od Boga...

\section{JONATHAS}

Ten Bóg, sprawiedliwy sędzia, który prędzej czy później nadgradza prawdziwą cnotę, on cię oświeca i prowadzi. W Rama ${ }^{14}$ byłeś przyjętym przez umierajacego Samuela ${ }^{15}$. Wielkie wypadki przyszłości przepowiedział ci ten najwyższy kapłan, który dawniej dał ojcu naszemu koronę. Ty jesteś dla mnie istotą równie miła, jak święta. Nie obawiam ja się dla ciebie niebezpieczeństw wojny, ale sideł bezbożnego dworu. Zdrada mięszka wokoło królewskich namiotów, śmierć towarzyszy jej wszędzie, a Saul oszukany przez Abnera najczęściej ją niewinnym posyła. Dawid, zaklinam cię, ukrywaj się, aż póki trąba wojenna nie odbije się o te góry. Rozumiem, że dzisiaj będziemy przymuszeni wydać potyczkę. —

\section{DAWID}

Mamże ukrywać szlachetny zamysł jakby podłą zdradę? Saul wprzód mnie zobaczy niż Filistynów. Niosę w mej duszy, czym zawstydzić mogę nieprzyjaciół moich i poruszyć najtwardsze serca. Chcę pierwej wystawić się na gniew króla, niżeli na pociski Filistynów. - O, królu! Cóż powiesz, kiedy jak niewolnik jaki schylę przed tobą poniżone ${ }^{16}$ me czoło? Cóż powiesz, kiedy mąż córki twojej błagać cię będzie o darowanie winy, której nie popełnił? Cóż powiesz naresz-

${ }^{14}$ Rama - miasto w Palestynie; można je utożsamiać z nowotestamentowa Arymateą i ze współczesnym Rentis, położonym około 29 km na wschód od Joppy. Tutaj mieszkał i został pochowany Samuel, zob. przyp. 15 (1 Sm 7,17).

${ }^{15}$ Samuel — prorok i ostatni sędzia izraelski, kapłan świątyni w Szilo; żył w IX w. p.n.e. Zjednoczył wszystkie plemiona izraelskie do walki z nacierającymi wrogami: Amonitami, i Amalekitami. Pobił Filistynów, ale nie będąc wojownikiem, wysunął na wodza plemion izraelskich Saula i namaścił go na króla. Przeprowadził reformy religijne. Schronił się u niego Dawid podczas ucieczki przed gniewem króla Saula (1 Sm 19,18-23).

${ }^{16}$ ponižony — tu: uniżony, uległy, zdominowany. 
cie, kiedy twój obrońca, twój wierny towarzysz stanie przed tobą jak ofiara twej złości? - Prawda jest, że prorok święty przyjął mnie w Rama ${ }^{17}$ przed swoją śmiercią, że mówił ze mną jak ojciec i skonał na moim łonie ${ }^{18}$. Dawniej kochał on Saula jak własnego syna, ale jakąż za to zyskał nagrodę? Samuel jednak umierając, nakazywał mi nienaruszoną wiarę i miłość dla króla, równie jak ślepe posłuszeństwo na wszystkie Najwyższego wyroki. Osta $<\mathrm{t}>$ nie słowa jego wyryte są na sercu moim i nigdy ich nie zapomnę. „Nieszczęśliwy Saulu” — mówił on — , ,jeżeli nie wnijdziesz ${ }^{19}$ sam w siebie, gniew Boga uderzy twoję występna głowę". - O, Jonathas! Chciałbym ciebie ochronić przed gniewem nieba, a może ochroniłbym i Saula, gdyby porzucił swe błędy. Biada nam, jeżeli Bóg wypuści piorun, który wisi nad głowami naszymi! Ty wiesz, jak często w gniewie swoim zmieszał niewinnego z występnym; jego ogniste pociski uderzając w tę ziemię, niszczą zarówno jadorodne jak i uzdrawiające zioła.

\section{JONATHAS}

Dawid, ty uprosisz łaskę Przedwiecznego dla Saula. Widziałem cię często w snach moich, a widok twój tyle uszanowania wrażał ${ }^{20}$ we mnie, że padałem na kolana przed toba. Nie mówię ci już nic więcej i ty nie potrzebujesz mi nic więcej mówić. Póki ja żyć będę, poprzysięgam ci, że miecz Saula nie zakrwawi twych piersi. Ale lękam się sideł, które ci zastawić mogą... Jakżebym je zwrócić potrafił! Tu, wśród uroczystości, wśród zabaw, przy odgłosie przyjemnych harmonii wypija się częstokroć śmierć z zdradliwych pucharów! Któż cię od tego zasłoni?

\section{DAWID}

Bóg Izraela, jeżeli chce, ażebym uniknął śmierci. - Ale powiedz mi, nie mogęż wprzód zobaczyć żony mojej niźli twojego ojca? Nie wolno mi jest wniść do tego namiotu aż po wschodzie słońca.

\section{JONATHAS}

Rozumiesz ty, że ona doczekuje dnia na samotnym swym łożu? Często przed wschodem jutrzenki przychodzi tu płakać wraz ze mna; tu posyłamy oboje do nieba modły o uzdrowienie ojca. — Ale spostrzegam w bliskości jakieś białe

\footnotetext{
${ }^{17}$ Rama - zob. przyp. 14.

18 tono - dolna część brzucha.

19 wnijsíc - wejść.

${ }^{20}$ wrąić - włożyć, wpuścić.
} 
szaty. Może to ona. Oddal się na stronę i słuchaj. Jeżeli to kto inny, nie pokazuj się, zaklinam cię.

\section{DAWID}

Przyrzekam ci to.

\section{Odchodzi na strone}

\section{SCENA III \\ MICHOLA I JONATHAS \\ MICHOLA}

Nocy bez końca i obrzydła, nigdyż nie ustapią twe cienie?... Ale powrót słońca przyniesież mi jaką pociechę? - Nieszczęśliwa! Widzę się pogrążoną na wieki w otchłani boleścil — O, mój bracie, ty wyszedłeś przede mną, a jednak udręczenie, które mnie bezustannie pożera, jest gwałtowniejszym od twego. Jakże mogłabym spoczywać na puchu, kiedy mój mąż, jedyne dobro moje, wygnany, błakający się, leży pewnie na gołej ziemi albo w jaskini dzikich zwierząt, których stać się może pokarmem!... Królu nieludzki! Wyrodny ojcze! Wydzierasz własnej córce jej męża, a masz tyle okrucieństwa, że jej życie zostawiasz! Słuchaj, bracie, już tu dłużej zostać nie mogę. Jeżeli pójdziesz ze mną, dopełnisz twej powinności; jeżeli nie chcesz mi towarzyszyć, puszczam się sama w ślady męża mojego; chcę znaleźć Dawida albo śmierć.

\section{JONATHAS}

Wstrzymaj się do czasu. Uśmierz twe bóle. Może Dawid przyjdzie do Gelboë21.

\section{MICHOLA}

Co mówisz? Dawid miałby się pokazać w miejscu, w którym się Saul znajduje? —

\section{JONATHAS}

Serce Dawida będzie wiecznie w tym miejscu, gdzie się Jonathas i Michola znajduja. Rozumiesz więc, że bojaźń więcej nim włada jak miłość? Dziwiłożby cię, gdyby on miał śmiałość zbliżyć się do nas?

${ }^{21}$ Gelboë-zob. przyp. 2. 


\section{MICHOLA}

O, Boże! Lękałabym się o niego, ale na sam widok...

\section{JONATHAS}

A gdyby się nie miał czego obawiać, gdyby śmiałość poparta powodami sprawiedliwymi... Słuchaj. Wiesz dobrze jak Saul mniej zawzięty w nieszczęściu, niż kiedy się fortuna uśmiecha, nie ufa dziś w swe siły. Rozumiesz, że on nie zna tego, iż niezwyciężone ramię Dawida pokonałoby hordy ${ }^{22}$ nieprzyjaciół? Przez pychę ukrywa on niespokojność swoję, ale każdy z nas czyta z jego twarzy, że nie ma żadnej nadziei zwycięstwa. Może bez gniewu widziałby teraz Dawida stawającego przed sobą.

\section{MICHOLA}

Gdyby to było!... Ale Dawid daleko jest od nas! — Ach! Gdzież się teraz obraca $^{23}$ ? W jakim stanie?...

\section{JONATHAS}

Jest bliżej, niżeli sądzisz.

$$
\text { MICHOLA }
$$

Nieba! Jakaż nadzieja?... Mój mąż...

\section{SCENA IV \\ DAWNIEJSI I DAWID \\ DAWID}

Twój mąż stoi przy tobie.

\section{MICHOLA}

Ach! Ten głos... O, szczęśliwości!... Nie mogę mówić... Prawdaż to, iż cię trzymam w moim objęciu?

22 borda - zgraja, tłum.

${ }^{23}$ obracaí się — tu: znajdować się, pomieszkiwać, przebywać. 


\section{DAWID}

O, najdroższa małżonko!... Srogie oddalenie!... O, śmierci, jeżeli masz dziś mnie uderzyć, umrę przynajmniej obok osób, które kocham nad życie! Lepiej jest umrzeć, niżeli żyć, błąkając się w pustyniach, gdzie ani czuć, ani wzbudzać nie można przyjaźni. Czekam cię, Saulu. Nasyć pragnienie krwi mojej. Uderz; oczy moje zamknie czuła małżonka, ciało moje położy w grobie i obleje mnie łzami prawdziwej miłości. —

\section{MICHOLA}

Dawidzie! Ty celu wszystkich moich nadziei, twój powrót rozpędził me troski. Nie na próżno zapewne ten Bóg, który cię z tylu wyrwał niebezpieczeństw, dzisiaj cię w te miejsca sprowadza. Ileż dzielności duszy wlewa we mnie twój powrót! Drżałam o ciebie nieprzytomnego, teraz już prawie spokojna jestem... Ale co widzę? W jakże lichej szacie pokazuje cię przede mną wschodząca jutrzenka? Wyzułeś się ${ }^{24}$ z całego twojego blasku! Purpura tkana rękami moimi nie okrywa cię więcej! Pod tym nędznym odzieniem któżby poznał królewskiego zięcia? W tej prostej zbroi ledwo cię za pospolitego wziąć można żołnierza.

\section{DAWID}

Jesteśmy w obozie, nie w pałacach. Tu płaszcz gruby i oręż są pompa ${ }^{25}$, która mi przystoi. Znajdę ja dziś w krwi Filistynów purpurę świetniejszą nad dawną. Ufaj równo ze mną, że wielki Bóg Izraela wyrwie mnie od śmierci, jeżelim nie zasłużył na nią.

\section{JONATHAS}

Noc ustępuje już dniowi; nie bawmy ${ }^{26}$ tu dłużej. Dawidzie, chociaż twój powrót może się użytecznym ojcu mojemu wydawać, postępuj jednak roztropnie. Każdego poranku ma on zwyczaj przechodzić się wraz z nami. Uważać będziemy, jeżeli ${ }^{27}$ ten czarny smutek, który go zawsze pożera, mniej go dziś dręczy. Z wolna i ostrożnie przysposabiać go będziemy do widzenia ciebie. Jeżeli chwila będzie pomyślną, stawimy cię przed nim pierwej ${ }^{28}$, nim go kto

\footnotetext{
24 wyzuć sie (z czego) — wyzwolić się, oswobodzić, uwolnić.

${ }^{25}$ pompa — wystawność, okazałość, świetność (fr.)

26 bawić — tu: przebywać, znajdować się, spędzać czas.

27 ję̧eli — tu: czy.

${ }^{28}$ pierwej — wcześniej, najpierw, uprzednio.
} 
uwiadomi ${ }^{29}$ o twoim powrocie. Staraj się, ażeby cię nikt nie poznał. Gdybyś był teraz postrzeżonym, Abner mógłby cię kazać zamordować. Spuść naocznik twojego hełmu, wmięszaj się pomiędzy żołnierzy wychodzących z namiotów i czekaj na ustroniu, póki sam nie przyjdę albo cię zawołać nie każę. -

\section{MICHOLA}

Jakże Dawid ukryć się może pomiędzy prostym żołnierstwem! Któryż rycerz zdoła się z nim porównać? Ach! Ukryj się raczej, drogi małżonku, póki ja sama nie przyjdę po ciebie. Nieszczęśliwa! Ledwom cię znalazła, już cię porzucać muszę. Ale to na kilka chwil tylko, a potem już nigdy, nigdy ciebie nie odstapię. Teraz chcę zabezpieczyć twe życie. Patrzaj, widzisz w ustroniu tego gęstego lasu głęboka jaskinią. Tam to częstokroć, opuszczona od całego świata, o tobiem myślała, ciebiem wzywała i łzami boleści oblewałam nieczułe kamienie! Ukryj się w tej jaskini, aż przyjdzie czas, ażebyś się pokazał.

\section{DAWID}

Michola, chcę ci być posłusznym. Bądźcie pewni oboje, że roztropnie postępując, nic ślepemu nie powierzę losowi. Kocham was, dla was żyć pragnę i ufam w obronę Pana astępów. -

\section{Koniec aktu pierwszego}

${ }^{29}$ uniadomić — oznajmić, dać wiadomość, donieść. 


\section{AKT II}

SCENA I

\section{SAUL, ABNER}

SAUL

Jak ten poranek jest piękny! Dziś wschód słońca nie okrywa się krwawym obłokiem! Miałżeby obiecywać mi dzień szczęśliwy? — O fortunne czasy młodości mojej, gdzież jesteście? Nigdy Saul nie wychodził z namiotu do boju, ażeby nie był pewny, że powróci do niego zwycięzcą. -

\section{ABNER}

O, królu! Dlaczegoż nie dowierzasz twojej odwadze? Czyliż nie poniżyłeś pychy Filistynów! Wierzaj mi, panie, im więcej się ta bitwa odwłóczy, tym większą przyniesie ci chwałę. -

\section{SAUL}

Abner! Uważając bieg rzeczy ludzkich, łatwo poznać, jaka jest różnica między gorejąca młodością, a tym mdlejącym wiekiem, w którym człowiek wlecze się do grobu. Kiedy dzielna prawicą ${ }^{30}$ trzymałem wodze państwa, które dziś wolnieją w mych ręku; natenczas nie wątpiłem nigdy o zwycięstwie. — Nie tylko samą młodość straciłem! Obym miał jeszcze pomoc Najwyższego Pana!... A przynajmniej pomoc Dawida! —

\section{ABNER}

Pogardzaższe naszą... Czyliż to bez Dawida niepodobna zwyciężać? Och! Gdybym tak myślał, nie chciałbym dobyć pałasza ${ }^{31}$, chyba na przeszycie mojego bojaźliwego serca. Dawid jest pierwszą i jedyną przyczyną wszystkich twoich nieszczęśliwości.

\section{SAUL}

Nie, nie, moje nieszczęścia z straszliwszego wypływają źrzódła... Nadaremno chcesz przede mną ukrywać okropność stanu mojego. Och! Gdybym nie był, jak jestem, ojcem ukochanych dziatek, chciałżebym żyć, panować, zwyciężać? Już bym dawno znalazł śmierć, rzucając się wpośród nieprzyjaciół;

${ }^{30}$ prawica - tu: prawa dłoń.

${ }^{31}$ pałasz — broń biała o prostej obosiecznej głowni i rękojeści, często nachylonej. 
dawno zwaliłbym ciężar życia, który mnie z wolna domęcza. Wieleż to już lat upłynęło, jak widziano uśmiech na moich licach ${ }^{32}$ ! Dzieci moje, które mi są tak miłe, wzbudzają we mnie gniew przez swoje pieszczoty... Okrutny, niecierpliwy, pożerany od zgryzot, zawsze zajątrzony ${ }^{33}$, jestem ciężarem sobie samemu i tym wszystkim, którzy mnie otaczaja! W wojnie żądam pokoju; w pokoju goreję ${ }^{34}$ do wojny; gdy mi podaja puchar, zdaje mi się widzieć w nim truciznę; we wszystkich, którzy mnie kochaja, nieprzyjaciół znajduję... Złożony na asyryjskim ${ }^{35}$ łożu zdaje mi się, że leżę wśród jadowitych wężów. - Spoczynek mój jest bolesnym konaniem, sny moje okropnymi widziadły. - Na koniec, kto by uwierzył? Drżę za każdym odgłosem trąby wojennej. - Sądź więc, Abner, jeżeli ${ }^{36}$ dom Saula nie owdowiał po dawnej swojej świetności; sądź, jeżeli Bóg Izraela nie opuścił już Saula! Ty sam nawet, wszak wiesz to dobrze, ty, mój przyjaciel, mój krewny, wódz i podpora mojego wojska, ty częstokroć wydajesz się w oczach moich podłym dworakiem, nieprzyjacielem moim i zdrajcą. -

\section{ABNER}

Teraz więc, królu, kiedy zmysły twoje nie są w pomięszaniu, teraz zwróć uwagę na wszystko, co zaszło pod panowaniem twoim. Przypomnij sobie, że udręczenia twoje pochodzą od fałszywych proroków w Rama ${ }^{37}$. Któż pierwej odważył się przepowiadać ci, że Bóg odwrócił się od ciebie? Zuchwały, chytry Samuel, ten kapłan pyszny i zdradliwy. Tłuszcza ${ }^{38}$, którą się otoczył, powtarzała prze-

32 lico — twarz, oblicze, fizjonomia.

${ }^{33}$ zajatrzony - oburzony, zagniewany.

${ }^{34}$ goré́ - pałać, płonąć, palić się.

${ }^{35}$ Asyria - starożytne państwo w północnej Mezopotamii (obecnie Irak), położone pomiędzy rzekami: Tygrysem oraz Wielkim i Małym Zabem. Głównymi miastami były: Assur (pierwotna stolica kraju, od której państwo przejęło nazwę), Niniwa, Kalah. Przybywało tu wiele plemion, poszukujących stałych siedzib, ze względu na żyzność dolin rzecznych i możliwość zwiększenia obszarów ziemi uprawnej. Już w pierwszej połowie II tysiąclecia p.n.e. Asyryjczycy stali się twórcami silnego, jednolitego państwa opartego na zdyscyplinowanej i zorganizowanej armii. Król sprawował władzę absolutna; pełnił równocześnie funkcje arcykapłana i naczelnego wodza.

${ }^{36}$ jeżeli — tu: czy.

${ }^{37}$ Rama - zob. przyp. 14.

${ }^{38}$ ttuszrza - pospólstwo, zgraja, tłum. 
klęństwa jego. Okiem zawiści pożerał on koronę jaśniejąca na czole twoim, którą sobie przywłaszczał. Chciał on dawniej włożyć ją na swoję głowę, ale głos całego Izraela zawstydził jego żądze, gdy oświadczył, że chce króla wojownika. Oto jest cała zbrodnia, którą popełniłeś przeciwko Samuelowi. Przestał on nazywać cię wybrańcem Boga odtąd, jak ty przestałeś być podległym jego wyrokom. Jego groźby zastraszyły twój rozum, a Dawid wsparty jego przepowiednia, rozkrzewił pomięszanie w twych zmysłach. Niezwyciężonym jest Dawid w potyczkach, pozwalam ${ }^{39}$, ale był zawsze zwolennikiem Samuela, obstając ${ }^{40}$ za sprawą ołtarza; był rycerzem w swych czynach, ale w głębi serca kapłanem. - Poznaj nareszcie prawdę; niechaj stanie w twych oczach obnażona z wszystkiego, co by ją zakrywać mogło. - Ja jestem z krwi twojej. Sława twoja nieoddzielną jest ode mnie, ale Dawid nie może wznieść się, nie strąciwszy pierwej Saula z tronu. -

\section{SAUL}

Dawid!... Nienawidzę go... Ale jednak dałem mu córkę za żonę... Ach! Ty nie znasz wszystkich moich męczarni. - Ten głos okropny, ten sam głos, który kiedym jeszcze był młodym i nieznanym od świata, kiedy nie czułem w sercu żadnej chęci panowania, każdej prawie nocy wzywał mnie do tronu; ten sam teraz straszliwy głos przerywa sny moje, a podobny do jęczącego szumu wzburzonego morza, woła na mnie: „Saulu! Ustąp z tronu, ustąp z tronu i złóż koronę!”. Święty, czci godny prorok, którego dawnej widziałem we śnie zwiastującego mi, że Bóg wybrał mnie królem Izraela, ten sam Samuel objawia mi się teraz w ciemnościach nocy, ale z twarzą zagniewaną i srogą. Widzę się przeniesionym w głęboką i czarna pustynia, Samuel spoczywa na promienistej górze, a Dawid klęczy przy nogach jego. Szanowny starzec, poświęconym olejem namaszcza jego czoło, a długa ręką, która aż do mnie sięga, zdziera koronę z mej głowy i chce nią uwieńczyć Dawida. - Ale któż uwierzy? Pobożny Dawid zniża się aż ku ziemi, nie ch<c $>$ e jej przyjać, a łzami zalany błaga proroka, ażeby ją włożył znowu na moję głowę. — Co widzę? O synu, o Dawidzie! Ty więc jeszcze chcesz mi być posłusznym, jeszcze jesteś moim zięciem, moim przyjacielem! — O, wściekłości! Wydzierać mi koronę! Drżyj, drżyj zuchwały starcze, który się na to odważasz!... Któż ty jesteś? Niechaj zginie bezbożny, który to zamyślał... Ach! Nieszczęśliwy! Gdzież jestem?...

\footnotetext{
${ }^{39}$ pozwalać - tu: potwierdzać, oświadczać, ręczyć.

40 obstawaí - trwać, pozostawać.
} 


\title{
ABNER
}

Niechaj Dawid sam zginie! Twoje sny, twoje widziadła, twoje trwogi, wszystko z nim razem zniszczeje! -

\section{SCENA II}

DAWNIEJSI, JONATHAS, MICHOLA

\author{
JONATHAS
}

Niech pokój będzie z królem moim.

\section{MICHOLA}

Niechaj Bóg z ojcem moim będzie!

\section{SAUL}

Rozpacz zawsze jest ze mna. - Dziś raniej jak zwyczaj wyszedłem z mojego namiotu i w niejakiej nadziei... ale ta nadzieja znikła natychmiast jak przemijające obłoki. — Mój synu, na cóż się zdało odwłóczyć potyczkę? Bojaźń zniszczenia okropniejszą jest nad samo zniszczenie! Dziś pierwszy raz bądźmy zwyciężeni. Chcę, ażeby natychmiast stanęło wojsko do boju.

\section{JONATHAS}

Dziś zwyciężymy zapewne. Powróć sercu twojemu nadzieję, mój ojcze, nigdy nie miałeś większych powodów spodziewać się wygranej. Wypogódź czoło twoje, ja pewny jestem zwycięstwa. Wkrótce te pola okryte zostaną trupami nieprzyjaciół naszych. -

\section{MICHOLA}

Tak ojcze, niezadługo powrócimy do spokojnych przybytków, wkrótce ujrzymy się w twoim pałacu. Spoczywając wpośród palm zwycięskich, będziesz szczęśliwym; ale czy zechcesz naówczas podzielić szczęście twoje z córka, powracając jej męża? -

\section{SAUL}

Jako, Micholo! Czyliż nigdy nie przestaniesz płakać? Takież to są przyjemne widoki, które wystawiasz ${ }^{41}$ dla uspokojenia zmęczonego cierpieniem oj-

\footnotetext{
${ }^{41}$ wystawiać — tu: ukazywać, uwidoczniać, przedłożyć.
} 
cowskiego serca? Także to pocieszasz me troski? Oddal się, córko boleści, oddal się!

\section{MICHOLA}

Nieszczęśliwa! Nie mamże płakać, mój ojcze? Któż, jeżeli nie ty, pogrążyłeś mnie w smutku?

\section{JONATHAS}

Przestań, Micholo. Chceszże bardziej jeszcze udręczać ojca? — Saulu, bądź szczęśliwy. Wschodząca jutrzenka duchem odwagi natchnęła ludy Izraela. Wkrótce pewny będziesz zwycięstwa. -

\section{SAUL}

Chceszże znikomą upojać mnie nadzieją? O jakimże to mówisz mi zwycięstwie? Płaczcie raczej wszyscy. Dzisiaj starożytny dąb, który ku obłokom wybujałe wznosił gałęzie, upadnie wyrwany z ziemi aż do najmniejszych korzeni. Ten dzień będzie dniem łez, krwi i śmierci! Zedrzejcie wasze odzienia, posypcie głowy wasze popiołem; dzień ten okropny jest ostatnim, który nam przyświeca!

\section{ABNER}

Mówiłem wam już tylokrotnie, że przytomnośćc ${ }^{42}$ wasza pomnaża jego cierpienia. -

\section{MICHOLA}

Niestety! Mamyż opuszczać ojca, którego kochamy?

\section{JONATHAS}

Chceszże ty sam tylko zbliżać się do ojca naszego?

\section{SAUL}

Co widzę? Zagniewanie na twarzach mych dzieci? Któż ich obraził? Czyli nie ty, Abnerze? Sa one z krwi mojej, czy nie wiesz o tym? - Pamiętaj, żebyś...

\section{JONATHAS}

Ach! Tak, jesteśmy krwią twoją i gotowi poświęcić życie nasze za ciebie.

\footnotetext{
${ }^{42}$ praytomnosí - tu: obecność.
} 


\section{MICHOLA}

O, mój ojcze, nie rozumiej, że własnemu tylko dobru dogodzić pragnę, kiedy żądam od ciebie powrotu męża. Szukam ja w nim nadziei Izraela, pogromu Filistynów, najdzielniejszego twojego rycerza. W posępnych chwilach, kiedy okropne widziadła zastraszały twój umysł, anielskie hymny Dawida nie pocieszałyż ciebie? Przyznaj ojcze, nie byłże on dla ciebie jaśniejącym promieniem wpośród ciemności?

\section{JONATHAS}

A ja, jeżeli umiem władać orężem ${ }^{43}$, komuż to winienem, jeżeli nie Dawidowi? Jeżelim co sławnego dokonał, szedłem w ślady najpierwszego z wojowników. Czy mówiono by dotąd o wojnie, gdyby tu był Dawid przytomny? Ach! Pokój dawno by już uszczęśliwiał ludy Izraela. -

\section{SAUL}

O, czasy młodości mojej! O, szczęśliwe dni moich tryumfów! — Wszystkie moje dawne zwycięstwa stawają mi przed oczy... Powracam z bitwy oblany potem i szlachetnym okryty kurzem. Wjeżdżam po wałach wzniesionych z ciał Filistynów. - Chwała Panu na wysokości! - Ale co mówię? Ja mam chwalić Pana Zastępów, kiedy on odwrócił ode mnie oczy, zamknął uszy na modły moje!... Gdzież jest dawna sława moja? Nie widzę już teraz płynącej krwi nieprzyjaciół moich...

\section{JONATHAS}

Całe wsparcie twoje, królu, było w Dawidz $<\mathrm{i}>\mathrm{e} \ldots$

\section{MICHOLA}

A Dawida nie ma dziś z nami. Oddaliłeś go z twojej przytomności ${ }^{44}$, wypędziłeś go z kraju, chciałeś ażeby mu śmierć zadano!... Dawid, twój syn, gotowy zawsze być ci posłusznym... Kocha cię bardziej niż własne twoje dzieci... Ach! Ojcze mój...

\section{SAUL}

Czuję, że łzy zalewają me oczy. Któż je wyciska? Ach! Dajcie mi pokój. Jużem od dawna odzwyczaił się płakać!

${ }^{43}$ oręż - broń, uzbrojenie.

${ }^{44}$ praytomnosśc - tu: obecność. 


\section{ABNER}

Pójdź, panie, do twojego namiotu. - Wkrótce przedstawię ci wojsko gotowe do boju i dowiodę ci, że Dawid nie ma nic więcej...

\section{SCENA III}

DAWNIEJSI I DAWID

DAWID

Nic, oprócz niewinności swojej.

SAUL

Co widzę?

$$
\text { MICHOLA }
$$

O, Boże!

$$
\text { JONATHAS }
$$

Cóżeś uczynił?

\section{ABNER}

Ten zuchwały...

$$
\text { JONATHAS }
$$

Ojcze mój...

$$
\text { MICHOLA }
$$

Ojcze, to jest mój mąż, mąż, którego mi sam dałeś.

$$
\text { SAUL }
$$

Co za okropny widok!

\section{DAWID \\ u nóg Saula}

Królu, chciałeś mojej głowy, szukasz jej od dawna... Oto jest, niechaj spadnie przy nogach twoich; do ciebie należy. 


\section{SAUL}

Co słyszę? Dawid... Bóg mówi przez ciebie; Bóg cię zesłał do tego obozu.

\section{DAWID}

Tak królu. Bóg to jest; ten sam Bóg, który niegdyś w Ela ${ }^{45}$, słabego jeszcze i bez doświadczenia młodzieńca stawił mnie przeciw Goliatowi ${ }^{46}$, olbrzymowi okrytemu żelazem; ten Bóg, który pókim pod twoimi walczył rozkazy, pomnażał zwycięstwa twoje; ten Bóg, który niedocieczony ${ }^{47}$ w układach swoich, użył do zdziałania wielkich rzeczy, ręki słabej i w poniżeniu ukrytej; ten to Bóg, Saulu, sprowadza mnie tu dla zrobienia ciebie zwycięzca. Daj mi dowództwo albo użyj mnie jak prostego żołnierza, wszystko mi równo ${ }^{48}$. Niech tylko nieprzyjaciel twój zginie, niechaj czarne obłoki otaczające twój tron tchem akwilonu ${ }^{49}$ rozpędzone zostana; dosyć mi na tym, Saulu, wtenczas mogę umierać; wtenczas nic cię wstrzymywać nie będzie do wskazania ${ }^{50}$ mnie na śmierć. „Niech zginie Dawid” — zawołasz, a natychmiast Abner zamorduje Dawida. — Nie będę ja się zbroił dla mojej obrony. W pałacu mojego króla nie powinienem mieć innej broni oprócz mojej niewinności, posłuszeństwa i prośby. - Jeżeli Bóg tak każe, powinienem umrzeć jako twój syn, nie jako twój nieprzyjaciel. - Syn Abrahama, gotowy jak ja przelać krew swoję na ołtarzu, przez słowa i czyny pokorne tylko okazywał posłuszeństwo. W chwili, kiedy ojciec podnosił rękę na zadanie mu śmierci, Izaak drugą z przywiązaniem

${ }^{45}$ Ela — dolina ciąnąca się od równin w pobliżu filistyńskich miast: Gat oraz Ekron, dalej wznosząca się poprzez Szefelę ku górom Judzkim.

${ }^{46}$ Goliat - wojownik olbrzymiego wzrostu, uczestnik wojny filistyńsko-izraelskiej. Swoją budową i siłą budził strach wśród żołnierzy nieprzyjacielskiego obozu. Wyzwał na pojedynek dowolnego przeciwnika z wojska izraelskiego zapowiadając, iż kto zostanie pokonany w tej walce, tego obóz stanie się poddanym zwycięzcy. Wówczas do walki zgłosił się młody pasterz trzód - Dawid, późniejszy król Izraela. Goliat mimo doskonałego uzbrojenia został pokonany w pojedynku celnym strzałem z procy. (1 Sm 17,1-50). Walka położyła kres wojnie i zadecydowała o losie dwóch narodów. Porównywano z nią indywidualne pojedynki bohaterów Iliady.

${ }^{47}$ niedocieczony — niezbadany, niezgłębiony, nieprzewidywalny.

${ }^{48}$ wszystko mi równo — wszystko mi jedno, obojętne, bez różnicy.

49 akwilon - porywisty wiatr północny lub północno-wschodni; jego uosobienie u starożytnych Rzymian (gwałtowny burzliwy i niebezpieczny dla żeglarzy wiatr), utożsamiany również z greckim Boreaszem.

${ }^{50}$ wskazać - tu: skazać. 
całował. - Ja naśladować go pragnę. Saulu, ty mnie z niczego wyniosłeś, ty mnie poniżyć możesz; ty okryłeś mnie sława, ty mnie z niej obnażyć możesz; ty mnie na szczycie postawiłeś godności i ty mnie strącić z niego możesz.

\section{SAUL}

Te wyrazy rozpędzaja gęsty obłok zasłaniający me oczy; doszły one aż do głębi serca mo $<$ j>ego. - Dawidzie, ty mówisz jak człowiek wspaniały i ty byłeś nim zawsze, ale zaślepiony wyniosłością odważyłeś się gardzić mną, wynosić się nade mnie, przywłaszczać sobie sławę moję i okrywać się dostojeństwy moimi. Gdybym nawet nie był twoim monarchą młodzian jeszcze, powinienżeś był natrząsać się z mojej starości? Wielki zawsze we wszystkich twoich dziełach, nie byłeś nim w tym czynie. Córki Izraela opiewając pochwały twoje, mówiły: „Dawid pobił tysiąc Filistynów, a Saul sto ich tylko pokonał”. Te przesady pochwał obrażały mnie, Dawidzie, bo czemuż nie mówiono: „Saul w młodości swojej tysiące nieprzyjaciół pokonał; on to nauczył Dawida zwyciężać”.

\section{DAWID}

Nie przestawałem ja przed ludem powtarzać codziennie, że ci wszystko winienem; ale ci, którzy podchwycili zaufanie twoje, wołali codziennie: „Dawid nazbyt możnym się staje, imię jego jest we wszystkich ustach, we wszystkich sercach; jeżeli go nie zgubisz, któż poskromi wyniosłość jego?” Abner, czemuż z mniejszą chystrością a większą prawdą nie mówiłeś królowi: „Dawid lepiej służy ci ode mnie, dlatego nienawidzę go, obawiam go się i zguby jego pragnę”.

\section{ABNER}

Zdrajco! Przypomnij sobie owe czasy, kiedy znosiłeś się ${ }^{51}$ z fałszywymi prorokami; kiedy haniebne spiski knowałeś ${ }^{52}$ na twojego monarchę; kiedy zbiegły pomiędzy Filistyny pędziłeś tam dni występne w porozumieniu z zdrajcami ukrytymi w obozie naszym; powiedz, powinieniemże by wtenczas mówić za tobą? Pamiętasz zapewne, jak niezhańbionego jeszcze zalecałem cię codziennie Saulowi, jak nakłoniłem go do wybrania ciebie za zięcia.

\section{MICHOLA}

To ja sama dokazałam, Abnerze; ja wyprosiłam od ojca za małżonka Dawida. Ujęta cnotą i zaletami jego, chciałam być z nim wiecznie złączoną. On był ce-

51 znosić się (z kim) — naradzać się, radzić się kogoś, porozumiewać się.

52 knowaí — intrygować, spiskować. 
lem tajemnych myśli, jedynym chęci moich zakresem, pierwszą mych wzdychań podnieta. W poniżonym ${ }^{53}$ stanie, wydanego na okropność nędzy, przeniosłabym była przecież Dawida nad wielbionych całego wschodu monarchów. -

\section{SAUL}

Ale ty, Dawidzie, jakże zbijesz oskarżenia Abnera? Wyznaj prawdę; nie zbiegłżeś do Filistynów? Nie rzucałżeś pomiędzy moich poddanych nasiona niezgody i buntu? Nie zastawiałżeś kilkakrotnie sideł na życie twojego króla, twojego drugiego ojca?

\section{DAWID}

Jedno słowo usprawiedliwi mnie, królu. Przypatrz się temu końcowi królewskiego twojego płaszcza: poznajeszże go?

\section{SAUL}

Oddaj. Poznaje go; na kim go zdobyłeś?

\section{DAWID}

Na tobie samym, a uciąłem go tym orężem ${ }^{54}$. — Przypominasz sobie doliny Engadda $^{55}$ ? Tam mnie wskazałeś ${ }^{56}$ na śmierć, tam zapalczywy; ścigałeś mnie wszędzie, a ja, sam, opuszczony od całego świata, ukrywałem się w jaskiniach zwierząt. Tam to jednego poranku snem zmorzony, leżałeś bez żadnej straży... Mógłżeś zasypiać nienawiścią dręczony?... Patrzaj, jak Stwórca naigrawa się z ludzkich układów; mogłem cię naówczas zabić i uciec, mogłem; mam oto oczywisty dowód. Monarcha tak wielki, wpośród swojego wojska był w ręku młodzieńca na śmierć skazanego!... Gdzież się wtenczas twój waleczny Abner znajdował? Także to służył swojemu panu? Poznaj teraz, w kim położyłeś zaufanie twoje, a przeciwko komu obróciłeś gniew i zemstę? — Nie dośćże masz na tym, o królu? Nie maszże teraz dostatecznych dowodów niewinności i wiary mojej? Nie maszże dostatecznych dowodów niedbalstwa i zdrady Abnera?

${ }^{53}$ poniżony — tu: upokorzony.

54 oręż - broń, uzbrojenie.

55 Engadda — właśc.: Engaddi, (hebr. 'Źródło Koźlęcia'), tereny pustynno-skalne nad brzegiem Morza Martwego, na szerokości geograficznej Zif. Tutaj Dawid uciekając przed gniewem zazdrosnego o sukcesy wojenne króla Saula, naszedł go w jaskini, gdzie akurat nie czuwały przy nim straże. Mimo sposobności do pokonania przeciwnika nie zgładził go, a jedynie odciął mieczem kawałek jego płaszcza (1 Sm 24,1-7).

56 wskazać — tu: skazać. 


\title{
SAUL
}

Zwyciężyłeś mnie, synu. — Abner, słyszysz to, a nie śmiesz mu odpowiedać. —

\section{MICHOLA}

O, radości!

\author{
DAWID
}

O, mój ojcze!

\section{JONATHAS}

Dniu szczęśliwy!

\section{MICHOLA}

Ukochany małżonku!

\section{SAUL}

Tak, dzień ten będzie dniem zwycięstwa, dniem szczęścia. Chcę Dawidzie, ażebyś dzisiaj przywodzi1 ${ }^{57}$ wojsku mojemu; Abner przystanie na to. Niechaj odtąd niezgoda wasza zamieni się w miłość braterska. Jonathas, ty walczyć będziesz przy boku przybranego brata... Dawid będzie mi poręką ${ }^{58}$ twojego, a ty Dawida życia.

\section{JONATHAS}

Kiedy nas Dawid prowadzi, Pan Zastępów jest poręką zwycięstwa. -

\section{MICHOLA}

Bóg, który cię powrócił twej żonie, czuwać będzie nad tobą.

\section{SAUL}

Nim się rozpocznie bitwa, pójdź do mojego namiotu, mój synu, i odpocznij na chwilę. Niechaj ukochana twoja małżonka umorzy bolesną tęsknotę, którą się w długiej niebytności twojej dręczyła; ona ci usługiwać będzie na uczcie, która ma być zakładem ${ }^{59}$ pojednania naszego. Ach, córko! Ty sama tylko możesz w umyśle Dawida zagładzić pamięć przykrości, które mu wyrządził uwiedziony twój ojciec.

\section{Koniec aktu drugiego}

${ }^{57}$ pryywodzić — właśc.: przewodzić, przewodniczyć.

${ }^{58}$ poreka - zapewnienie, poręczenie, gwarancja.

${ }^{59}$ zaktad — tu: dowód, potwierdzenie. 


\section{AKT III \\ SCENA I \\ DAWID, ABNER}

ABNER

Otóż jestem, Dawidzie. Ledwo co się skończyła uczta, natychmiast przychodzę odebrać twoje rozkazy.

\section{DAWID}

Chciałem rozmówić się z tobą na osobności.

\section{ABNER}

Chcesz mi zapewne mówić o bitwie, którą wydać mamy...

\section{DAWID}

I powiedzieć ci, że nie chcę, ażebyś pode mną służył, ale żebyśmy obadwa w jednym rzędzie walczyli razem za Izraela, za Saula i za Najwyższego chwałę. Abner, nie miejmy żadnych innych zamiarów.

\section{ABNER}

Ja, zrodzony z krwi królów, biłem się za Saula pierwej jeszcze, niżeli słyszano szum kamienia twej procy.

\section{DAWID}

Krew królów nie płynie w mych żyłach, nie przechwalam się z mych czynów; znane są wszystkim i Abner był onych świadkiem. Ale zapomnij o nich, nie pamiętaj tylko o twoich i staraj się dziś przewyższyć własne twe dzieła.

\section{ABNER}

Sądziłem się być aż dotąd najwyższym wodzem wojsk Izraela. Dawida tu nie było, wydałem więc rozrządzenia do bitwy. Dowiedz się o nich: obóz Filistynów leży przeciwko nam, na wzgórkach i rozciaga się od północy ku południowi. Gęste krzewiny ma za sobą, głębokie rowy na przodzie. Od wschodu zasłaniaja go nie $<z>$ dobyte szańce; od zachodu tylko możemy mieć przystęp przez góry. Tam to potrzeba się starać sprowadzić Filistynów, a pewni będziemy zwycięstwa. Ażeby tego dokonać, potrzeba najprzód zmyślić ucieczkę. Rozdzielając wojsko nasze na trzy części, przejdziemy około ich prawego 
skrzydła. Pierwszy oddział uciekać niby będzie bez zastanowienia, drugi zatrzyma się nieco na pobojowisku, a jego udane nieporządne cofanie, ściagnie ku niemu nieprzyjacielski zapęd. Wtenczas wybó ${ }^{60}{ }^{6 y c e r z y ~ n a s z y c h, ~ p r z e b y-~}$ wając szańce od wschodu, wpadnie z tyłu na Filistynów; pierwszy oddział zwróci się na ich skrzydło, a tak otoczonych z czoła, z boków i tyłu, okropnej poświęcimy ich rzezi. -

\section{DAWID}

Widzę w tobie tyle przezorności, ile odwagi. Abner, nic nie ma być odmienionym w twoim układzie. Szanuję cnotę wszędzie, gdzie ją znajduję; ja chcę służyć pod toba, a w czasie bitwy orężem tylko dopomagać rozkazom, które ty wydasz.

\section{ABNER}

Ach! Dawid to jest moim wodzem, ten Dawid tak wsławiony w boju. Któż inny oprócz niego potrafiłby kiedy zwyciężać?

\section{DAWID}

Ty, który tyle masz rozumu i zasług, chciałbyś jeszcze zawiścicić ${ }^{61}$ innym? Im więcej rozważam twój układ, tym go doskonalszym znajduję. Jonathas i ja będziemy zasłaniać królewski oddział. Sadok ${ }^{62}$ z tysiącem wybranych uderzy na szaniec $^{63}$, ty przywodzić będziesz środkowym hufcom ${ }^{64}$.

\section{ABNER}

Tyś tam być powinien. Ty masz objąć to pierwsze miejsce dostojeństwa.

\section{DAWID}

A więc rozkazuję ci być tam. - Słońce coraz bardziej się wznosi, bądź gotowy z całym wojskiem, ale niechaj głos trąby nie odzywa się aż nad samym wieczo-

${ }^{60}$ mybór — tu: część, fragment, składnik.

${ }^{61}$ zawiśsić (komu) — zazdrościć, czuć niechęć.

${ }^{62}$ Sadok - kapłan izraelski, syn Aarona, następca po Abiatarze (2 Sm 8,17). Jako wypełnienie proroctwa miał w Jerozolimie aż do wygnania wyłączność na kapłaństwo. Namaścił Salomona na króla (1 Krl 1,39), za jego panowania został arcykapłanem i jednym z najważniejszych dostojników. (1 Krl 4,2).

${ }^{63}$ szaniec - ziemne umocnienie polowe składające się z wału i rowu, stosowane w celu osłony i możliwości bezpieczniejszego przemieszczania się żołnierzy.

${ }^{64}$ bufiec - zwarta część wojska z zamkniętymi i ściśniętymi szeregami, przygotowana do ataku (niem.). 
rem. Wiatr zachodni dmie zazwyczaj gwałtowniej w tym czasie; nieprzyjaciel zamroczone mając oczy promieniami zachodzącego słońca i kurzem powstającego wichru, nie będzie mógł jasno widzieć obrotów ${ }^{65}$ naszych.

\section{ABNER}

Prawdę mówisz.

\section{DAWID}

Idź więc, rozkazuj, a przez nikczemne podstępy, których człowiek, jak ty, znać nie powinien, nie chciej poniżać sławy wielkiego wodza, której godzien jesteś. —

\section{SCENA II \\ DAWID}

sam

Porządek bitwy jest wielki i wybornie zabezpieczony. Ale na cóż się przyda roztropność i męstwo wodzowi, jeżeli nie posiada przywiązania swoich żołnierzy? Tego tylko nie dostaje ${ }^{66}$ Abnerowi, a Bóg obdarzył mię tym łaskawie. Dzisiaj zwyciężę, a jutro opuszczę króla. Nigdy ja przy nim nie znalazłbym pokoju... Co mówię? Nowe zwycięstwo byłoby wkrótce uważanym jak nowa zbrodnia.

\section{SCENA III}

\section{MICHOLA I DAWID}

\section{MICHOLA}

Najmilszy mężu, ty nie wiesz, co się znowu dzieje. Mój ojciec powracał z uczty naszej, w której znalazł niejaką pociechę, kiedy Abner odprowadziwszy go na stronę, rozmawiał z nim dość długo. Gdym się zbliżyła, on wyszedł i nie zastałam już króla takim, jakim był dawniej.

${ }^{65}$ obrót — tu: manewr, posunięcie, ruch.

${ }^{66}$ nie dostawaí — tu: brakować. 


\section{DAWID}

Ale cóż mówił? Cóżeś widziała?

\section{MICHOLA}

Nim rozmawiał z Abnerem, bawił się z nami; mięszał łzy swoje do naszych, przyciskał nas do serca i z radościa przewidywal, że potomstwo nasze będzie sławne i utrzyma chwałę Izraela. Okazywał ku nam przywiązanie czułego ojca; teraz widać w nim tylko obojętność monarchy.

\section{DAWID}

Najmilsza żono, nie rozpaczaj przed czasem. — Saul jest królem, wolno mu rozrządzać losem naszym, jak mu się spodoba. Teraz to jest jedynym moim życzeniem, ażeby dziś wygrał bitwę. Niechaj jutro powróci do swego gniewu, ja powrócę do nędznego mojego stanu; pójdę na wygnanie, będę uciekał i sam się wskażę ${ }^{67}$ na bolesne życie tułacza. Najdotkliwszym udręczeniem dla mnie będzie rozstanie się z toba, ale los przymusza nas do tego. - O, znikoma nadziejo! O, nieszczęśliwy związku. Powinnaś była obok innego małżonka używać pomyślności i blasku dostojeństwa twojego, a ja ci to wszystko wydarłem!... Nie będziesz mogła nieobecnemu i zawsze uciekającemu mężowi wydać licznego i sławę mnożącego potomstwa.

\section{MICHOLA}

Nie, Dawidzie, nie będziemy już więcej rozłączeni; nikt się nie odważy wydrzeć mnie $z$ twojego łona ${ }^{68}$. Nie chcę dłużej pędzić tak okropnego życia, jakie dotąd znosiłam. Nim mnie oddalą od ciebie, wprzód mnie zamordować musza. Samotna, łzami oblana, wlokłam długie dni w tym pomięszaniu ${ }^{69}$ boleści! Cienia nocne straszne mi wystawiały ${ }^{70}$ obrazy! Raz widziałam wzniesiony nad głowa twoją mściwy miecz ojca mojego, słyszałam błagający twój głos, głos przyjemny, który by i najsroższe potwory wzruszyć potrafił; a jednak srogi Saul zatapiał żelazo w twych piersiach! Drugi raz widziałam cię w ciemnej jaskini, ścielącego łoże twoje z suchych gałęzi. Drżałeś za najmniejszym szelestem, nie znajdując nigdzie pomocy ani spoczynku! Słaby, wyniszczony, pożerany gorącym pra-

${ }^{67}$ wskazać - tu: skazać.

${ }^{68}$ tono — dolna część brzucha.

${ }^{69}$ pomieszanie — pomylenie, zagmatwanie, obłąkanie.

${ }^{70}$ wystawiać — tu: ukazywać, uwidoczniać, przedłożyć. 
gnieniem... O, Boże! — Czyliż potrafię ci opisać bojaźń, rozpacz i męki, które zawsze napełniały mą duszę! — Ach! Nie, nie opuszczę cię więcej. —

\section{DAWID}

Wstrzymaj się. Rozdzierasz mi serce. Dzień ten nie łzy, ale krew ma widzieć płynąca.

\section{MICHOLA}

Byle tylko na tym dworze nie stawiono ${ }^{71}$ ci sideł, nie obawiam się niczego dla ciebie na polu bitwy. Najwyższy zasłaniać cię będzie. Może zdradliwy Abner przeszkadzać zechce twojemu zwycięstwu, albo odniesione za występek w oczach króla wystawiać.

\section{DAWID}

Jak to? Więc watpisz, ażeby Saul powierzył mi dokonanie dzisiejszej rozprawy?

\section{MICHOLA}

Nicem słyszeć nie mogła, ale widziałam go pomięszanego. Wspominał często o zdradliwych kapłanach, o szpiegach włóczących się po naszym obozie, o zmyślonej pokorze... Te niezrozumiane wyrazy słusznie przerażają trwoga niewiastę, która jest żoną Dawida, a córką Saula. -

\section{DAWID}

Otóż i on. Usłyszymy go zaraz.

\section{MICHOLA}

Sprawiedliwy Boże! Ześlij dziś pomoc słudze twojemu, zawstydź bezbożnego, oświeć ojca, ratuj małżonka i broń wybranego ludu Izraela!

\section{SCENA IV}

\section{DAWID, SAUL, JONATHAS}

\section{JONATHAS}

Pójdź, mój ojcze, rozpędź te ponure myśli. Czyste powietrze ułagodzi twoje cierpienia; pójdź i usiądź pomiędzy twoimi dziećmi.

\footnotetext{
${ }^{71}$ stawić (co) — właśc.: zastawić.
} 


\section{SAUL}

Któż to do mnie mówi?

\section{MICHOLA}

Ach! Mój ojcze...

\section{SAUL}

Któż ty jesteś? Któż mi to o czystym powietrzu wspomina? Ja nie widzę tylko czarne obłoki, ciemności nocy i widma śmiertelne!... Przybliż się do mnie. Patrzaj, czy nie widzisz jak słońce krwawym otacza się kołem? Nie słyszysz żałobnego hukania sowy? Pogrzebowe jęki odbijają się w powietrzu, przerażają me uszy i łzy wyciskaja z mych oczu!... Ale cóż to, i wy także płaczecie?

\section{JONATHAS}

Potężny Boże Izraela, już więc na zawsze odwróciłeś oczy twoje od Saula?... Był on twoim pokornym sługa, chceszże go wydać nieprzyjaciołom jego?

\section{MICHOLA}

Ojcze mój, masz przy sobie kochającą cię córkę. Jeżeli ty jesteś szczęśliwym i ona nią będzie, jeżeli ty płaczesz i ona płakać nie przestanie... Nasz obrońca powrócił...

\section{SAUL}

Chcesz o Dawidzie mówić?... Ach! Dawid!... Czemuż on nie ściska mnie razem z moimi dziećmi?

\section{DAWID}

Ojcze mój, stałem w oddaleniu z bojaźni, ażeby przytomność ${ }^{72}$ moja nie przyniosła ci przykrości. Ach! Czemuż w sercu moim czytać nie możesz! Jestem ja zawsze razem $z$ tobą.

\section{SAUL}

Więc ty kochasz pokolenie Saula?

\section{DAWID}

Jeżeli ${ }^{73}$ je kocham? O, Boże!... Jonathas jest mi milszym nad życie moje, a kiedy tobie usłużyć potrzeba, żadne niebezpieczeństwo wstrzymać mnie nie zdo-

${ }^{72}$ praytomność - tu: obecność.

${ }^{73}$ jè̇eli — tu: czy. 
ła. Co do mojej małżonki, kocham ją tak gorącym zapałem, że uczucia, które ona wznieca w mym sercu, wyrazić mi niepodobna.

\section{SAUL}

Jednakże ty masz wiele wyniosłości!

\section{DAWID}

Ja, wyniosłości? - Na pobojowisku nie umiem być bojaźliwym rycerzem; na twoim dworze masz we mnie posłusznego zięcia; w obliczu Boga... niczym jestem.

\section{SAUL}

Ale dlaczegóż zawsze wspominasz mi o Bogu, chociaż wiesz, że złość kapłanów od dawna już odwróciła ode mnie opiekę jego? Jestże to naigrawaniem się, że zawsze przywodzisz mi go na pamięć.

\section{DAWID}

Wspominam go dla oddania mu słusznego hołdu. Dlaczegóż wierzysz, mój ojcze, że Bóg opuścił ciebie? Nie wspiera on tych, którzy gardza jego pomoca, ale nigdy nie umknął prawicy wzywającemu i ufającemu dobroci jego. On cię osadził na tronie, on dotąd utrzymywał cię na nim; on będzie obroną Saula, jeżeli Saul w nim tylko zaufa.

\section{SAUL}

Któż mi to o Bogu rozprawia? Jestże to kapłan białą szatą odziany?... Obaczmy... Nie, ty jesteś żołnierz, oręż nosisz; przystąp, przybliż się, niechaj poznam czy to Samuel ${ }^{74}$ czy Dawid mówi do mnie? — Jakiż to jest miecz? To nie jest ten, który ja tobie dałem...

\section{DAWID}

Ten oręż, który mi zdobyła licha moja proca, ten oręż był niegdyś w Ela ${ }^{75}$ przez strasznego Goliata ${ }^{76}$ nad głową moją wzniesiony. Widziałem go błyskający jak piorun i niosący mi śmierć pewną. Goliat nim władał, chciał go zafarbować krwią moją ale ja zbroczyłem go jego własną. -

${ }^{74}$ Samuel — zob. przyp. 15.

${ }^{75}$ Ela - zob. przyp. 45.

${ }^{76}$ Goliat — zob. przyp. 46. 


\section{SAUL}

Nie byłże ten miecz zawieszonym w Nobbe $^{77}$ na świętym przybytku ${ }^{78}$ Pana? Nie byłże potem zawiniętym w Efodon ${ }^{79}$, zakrytym przed wzrokiem śmirtelnych i na zawsze poświęconym Najwyższemu?

\section{DAWID}

Nie inaczej.

\section{SAUL}

Powiedz więc, skąd go porwałeś, kto ci go wydał?

\section{DAWID}

Wyjawię ci rzetelną prawdę. Przybyłem do Nobbe jak zbieg; ty wiesz dobrze dlaczegom uciekał. Przymuszony bez oręża przebywać niebezpieczne drogi, co dzień wystawiony byłem na pociski śmierci. Upadłem w pokorze przed przybytkiem pańskim, na który Duch Święty zstąpił, któż inny jeżeli nie Dawid miał prawo do oręża, którego żądałem? Prosiłem kapłana o niego...

SAUL

I kapłan...

${ }^{77}$ Nobbe — właśc. Nob; miasto położone na wschodnim stoku góry Skopus, na wschód od Jerozolimy. Tu schronili się kapłani z Szilo po ataku Filistynów (1 Sm 4), dlatego też tutaj przybył Dawid w czasie ucieczki przed gniewem króla Saula. Kapłan Achimelek udzielił pomocy; ze Świątyni Pańskiej podarował mu miecz Goliata oraz nakarmił go świętym chlebem (1 Sm 21,2-10). Kiedy dowiedział się o tym król Saul, dokonał w Nob rzezi kapłanów, a także ludu i bydła (1 Sm 22,6-19).

${ }^{78}$ praybytek — tu: namiot, w którym znajdowała się Arka Pańska, zob. przyp. 101. Przybytek, dosł.: „mieszkanie”, zgodnie z tradycją kapłańską jest nazwą pustynnego sanktuarium, dającego się zdemontować, czyli dostosowanego do częstej zmiany miejsca. Nazywany także „przybytkiem Świadectwa” lub „przybytkiem Namiotu Spotkania”. Dokładny opis wyglądu Przybytku opisuje Księga Wyjścia (Wj 26,1-37).

${ }^{79}$ Efodon — właśc.: efod; element liturgicznej szaty kapłańskiej, rodzaj fartucha podtrzymywanego paskiem i szelkami, do którego przymocowany był „,pektorał sądu" - znajdowały się w nim święte losy do radzenia się wyroczni. Efodon wykonywany był ze złotych nici, karmazynu, bisioru oraz czerwonej i fioletowej purpury. Pierwszym kapłanem przyodzianym w taką szatę był Aaron, brat Mojżesza (Wj 28,6-14). 


\section{DAWID}

Dał mi go natychmiast.

\section{SAUL}

A ten kapłan był...

\section{DAWID}

Achimeleck.

\section{SAUL}

Zdrajca! — Gdzie jest ołtarz! — O wściekłości! — Bezbożni! Wy jesteście nieprzyjaciółmi moimi, wy jesteście wspólnikami Dawida!... Dusze zdradliwe i chytre! — Gdzie są oprawcy? — Gdzie jest ołtarz? Niechaj go zburzą, niech zniszcza...

\section{MICHOLA}

Ach! Mój ojcze!

\section{JONATHAS}

Co czynisz? Dokąd bieżysz? — Uspokój twój gniew, zaklinam cię. Nie ma tu ołtarza. Szanuj namiestników Najwyższego, niechaj nie słyszą bluźnierstw twoich.

SAUL

Któż mnie zatrzymuje? Kto mnie przymusza siedzieć? Kto mi się opiera?

$$
\text { JONATHAS }
$$

Ojcze mój...

\section{DAWID}

Zlituj się nad nim, potężny Boże Izraela! Oto twój sługa na kolanach błaga cię za nim!

\section{SAUL}

Już na wieki wydarto mi spokojność; wydarto mi dzieci, królestwo i światło słoneczne! Nieszczęśliwy Saulu! Któż cię pocieszy? Kto prowadzić będzie kroki oślepionego ojca? Synowie twoi są niemi, nieczuli i barbarzyńcy!... Żądają prędkiej śmierci słabego starca; dzieci Saula nie myślą tylko o koronie, która okrywa siwe włosy jego. Zedrzyjcie ją oddzielcie chwiejącą się głowę 
ojca od ciała udręczonego boleścią. — Okropny stanie! Męczarnie bez końca! Śmierć znośniejszą mi będzie... O śmierć tylko was proszę.

\section{MICHOLA}

Ach! Ojcze, my prosimy Boga o przedłużenie dni twoich! Każde z nas gotowe jest na śmierć, byle ją od ciebie odwrócić.

\section{JONATHAS}

Zapalczywość jego koi się łzami. Użyj bracie słodko mamiącej harmonii twej harfy; zaśpiewaj boskie hymny twoje, które już nieraz wprawiały go w zapomnienie jego boleści.

\section{MICHOLA}

Widzisz, jak ledwo oddycha. Oczy jego zalane łzami. Trzeba mu ulgi nieodwłocznie $^{80}$.

\section{DAWID}

Oby sam Bóg przemówił przez usta moje!

Gtowa Saula spoczywa na piersiach Micholi siedzacej pray nim. Dawid siada z drugiej strony i praygrywajac na harfie, spiewa zpoczatku cichym glosem, który potem staje sie coraz. mocniejszym, w miare rzeczy jakie opiewa

\section{HYMN}

O, Bóstwo nieśmiertelne, przedwieczne, wszechmocne!

Coś świat z nicestwa wywiodło;

Ty, od światłości dziennej dzielisz cienia nocne;

W tobie wszech stworzeń jest źrzódło.

5 Przed tobą wszystko jawne i równe w naturze,

Tak sądzisz nędznych jak możnych;

Jednym skinieniem ręki uspokojasz burze

Lub rzucasz gromy w bezbożnych!

${ }^{80}$ nieodwłocznnie — właśc.: niezwłocznie. 


\section{E⿰口口阝}

Po skrzydłach cherubinów zstapiwszy na ziemię,

10 Wodza danego $z$ twej woli

Światłem mądrości darzysz; by wybrane plemię

Rządził i wywiódł z niewoli.

Ześlij i nam dziś światło, udziel nam obrony,

Daj ducha mocy i męstwa;

15 Lud Izraela w nędzy i łzach pogrążony,

Z twej ręki czeka zwycięstwa.

\section{SAUL}

Słyszę hymny Dawida. One rozweselają mój umysł, one mi przypominaja młodość moję.

\section{DAWID}

\section{spiewa dalej}

Któż to jest, kogo słyszę, a widzieć nie mogę?

Tuman ${ }^{81}$ go gęsty zakrywa...

Wtem wiatr wschodni z kurzawy oczyszcza mu drogę,

20 Saul z Izraelem przybywa!

Błyszczą złociste zbroje, lecz świetniejszy nad nie

Król ufny w prawicy Pana,

Wszystko, gdzie tylko z mieczem zagniewany wpadnie,

25 Pod swoje zgina kolana!

Synu Amnona ${ }^{82}$, gdzież jest twa pyszna ${ }^{83}$ swawola?

Gdzie twe pogróżki, twa siła?

${ }^{81}$ Tuman — kłębowisko, dym, obłok.

${ }^{82}$ Amnon — jeden z sześciu synów Dawida, urodzony w Hebronie (2 Sm 3,2-5). Zakochany w swojej przyrodniej siostrze Tamar, podstępem uwiódł ją i zgwałcił (2 Sm 13,1-19). Dwa lata później Absalom, rodzony brat Tamar, razem z pozostałymi synami królewskimi zabił Amnona (2 Sm 13 23-33).

${ }^{83}$ pyszny — tu: butny, hardy, zuchwały. 
Trupy twych zwolenników okryły te pola,

Wszystko śmierć prędka zgładziła!

Saby $^{84}, \mathrm{Moa}<\mathrm{b}>{ }^{85}, \mathrm{Edo}<\mathrm{m}>\mathrm{a}^{86}$ pokolenia sprośne

30 Saul w proch nikczemny obraca,

Jak potok, gdy z gór lecąc wezbrany na wiosnę,

Wszystko przed sobą wywraca!

SAUL

Ach! Te pieśni śpiewano mi w czasach mojej chwały, w dni świetne triumfów moich! Słysząc je, zdaje mi się, iż oddycham nowym powietrzem. One z nadbrzeża grobu wzywają mnie jeszcze do sławy! — Ale co mówię? Na cóż się zdadzą te wojenne okrzyki? Starość szuka tylko zacisza i spokojności duszy.

\section{DAWID}

Śpiewajmy pokój.

Rycerz trudami znużony

I wieńcem sławy okryty,

Powraca w spokojne szczyty,

$\mathrm{Na}$ łono dziatek i żony.

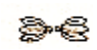

5 Rzuca się na jego szyję

Grono z krwi mężnej wydanych;

${ }^{84}$ Saba - syn Jokoszana, którego ojcem był Abraham (2 Krn 1,9).

${ }^{85}$ Moa $<b>$ — syn Lota i jednej z jego córek ( $\left.\mathrm{Rdz} 19,30-37\right)$. Od niego wywodzi się plemię Moabitów. Wg etymologii ludowej nazwa Moab jest tłumaczona jako mểab, czyli: ,ten, który wyszedł z ojca”. Moab to także nazwa miejscowości podbitej przez Króla Dawida. Mieszkańcy stali się poddani Izraelowi i zostali zmuszeni do płacenia daniny (2 Sm 8,2-3).

${ }^{86} E d o<m>$ - drugie, synonimiczne imię Ezawa, brata Jakuba, syna Izaaka (Rdz 25, 29-30). Wywodzi się z etymologii ludowej: Ezaw był czerwony ('admônî), dlatego został nazwany Edomem. Od niego wywodzi się lud Edomitów, rywalizujący z ludem Izraelitów (wywodzącym się od Jakuba), któremu został poddany; wolność zyskał ostatecznie w poł. IX w p.n.e. za panowania Jordana, króla judzkiego. Edom to również nazwa miejscowości podbitej za panowania króla Dawida (2 Sm 8,11-14). 
Już trosk niepomni cierpianych,

Szczęśliwe, bo ojciec żyje.

\section{急象}

Syn mu zdejmuje hełm z czoła,

10 Żona twarz jego obmywa;

Córka z pucharem przybywa,

$\mathrm{W}<$ s $>$ zystka czereda ${ }^{87}$ wesoła.

\section{影㖷}

Szczęśliwe pokoju chwile!

Chwile miłości i zgody;

15 Syty po trudach swobody

Bohatyr zasypia mile.

\section{SAUL}

Szczęśliwy ojciec takich dziatek. — O pokoju, o rozkoszy duszy cnotliwej!... Czuje pocieszający balsam po wszystkich mych żyłach. - Ale cóż to żądasz Dawidzie? Chcesz ty, ażeby Saul na łonie swojej rodziny gnuśniał ${ }^{88}$ w haniebnym zatopiony próżniactwie? Waleczny Saul, czy przestał już być strasznym na polu bitwy?

\section{DAWID}

Powróćmy do wojennych okrzyków.

Jak od lwa, choć snem zmorzony,

Nie straszy rykiem; z daleka

Cofa się pasterz strwożony,

20 A zwierz w swe jamy ucieka.

Tak, choć król mężny spoczywa,

Drżą jego nieprzyjaciele;

Wzmocniony, gdy miecz porywa,

Tym więcej trupem ich ściele.

${ }^{87}$ czereda - tu: zebrani członkowie rodziny.

${ }^{88}$ gnuśnieć — próżnować, lenić się, trwonić czas. 
25 Oto już powstał król dzielny,

Jak piorun na złych uderza;

Wszędzie cios niesie śmiertelny

I karę zdrajcom wymierza.

I ja chcę walczyć przy królu,

30 Chcę mu być pomoca, strażą

Złączone na bitwy polu

Dwa miecze więcej dokażą...

\section{SAUL \\ porywajac sie r. gniewem}

Któż to jest ten zuchwały? Możesz na polu bitwy inny miecz prócz mojego zwyciężać? Niechaj zginie, kto się nim pogardzać odważa!

\section{MICHOLA}

Wstrzymaj się, ojcze!

$$
\text { JONATHAS }
$$

O nieba! Cóż to zamyślasz?

DAWID

Nieszczęśliwy królu!

$$
\text { MICHOLA }
$$

Uciekaj, kochany mężu. Nie potrafimy go wstrzymać. Uciekaj.

\section{SCENA V \\ DAWNI, OPRÓCZ DAWIDA \\ MICHOLA}

Uspokój się, mój ojcze.

\section{SAUL}

Któż to się odważa zatrzymywać me ręce? — Gdzie jest miecz? Oddajcie mi mój oręż ${ }^{89}$.

\footnotetext{
${ }^{89}$ orę̇ं - broń, uzbrojenie.
} 


\section{JONATHAS}

Pójdź z nami, najmilszy ojcze, nie odstapimy ciebie. Patrzaj, nie ma tu już nikogo oprócz twych dzieci. Powróć z nami do twego namiotu, potrzebujesz spoczynku. Pójdź, uspokój gniew, wszak jesteś z twoimi dziećmi.

$$
\text { MICHOLA }
$$

Które cię nigdy nie odstappią.

\section{Prowadra go do namiotu}

\section{Koniec aktu trzeciego}




\section{AKT IV \\ SCENA I \\ JONATHAS, MICHOLA \\ MICHOLA}

Powiedz mi, Jonathas, czy mój mąż może powrócić do namiotu naszego ojca? JONATHAS

Nie. Ojciec nie zaspokoił się ${ }^{90}$ jeszcze. Powrócił nieco do zmysłów, ale zawiść jego względem Dawida jest silną i głęboko wkorzeniona. Wiele czasu potrzeba będzie, ażeby ja przytłumić. Powróć do męża, nie odstępuj go.

\section{MICHOLA}

Biada mi! Czyliż nie jestem najnieszczęśliwszą żoną! - Ukryłam Dawida w miejscu, w którym go niepodobna wynaleźć; powracam do niego.

\section{JONATHAS}

Wielki Boże! Spostrzegam ojca. Znowu jest w pomięszaniu. Nigdyż nie dozna spokojności umysłu?

\section{MICHOLA}

Cóż mu powiem? Uniknę raczej przed jego wzrokiem chce odejsć

\section{SCENA II \\ DAWNIEJSI I SAUL \\ SAUL}

Któż tu ucieka przede mną?

\section{MICHOLA}

Panie!...

\section{SAUL}

Gdzie jest Dawid?

\footnotetext{
${ }^{90}$ zaspokoić sie — tu: uspokoić się, oprzytomnieć, ochłonąć.
} 


\section{MICHOLA}

Nie wiem.

$$
\text { SAUL }
$$

Ty nie wiesz?

$$
\text { MICHOLA }
$$

Ojcze mój...

$$
<\text { SAUL }>
$$

Niech go szukaja, niech go przyprowadza przede mnie.

$$
\text { MICHOLA }
$$

Idę szukać go... Ale gdzie go znaleźć?

$$
\text { SAUL }
$$

Twój król rozkazuje, a ty nie jesteś posłuszną?

\section{SCENA III \\ SAUL, JONATHAS \\ SAUL}

Jonathas, kochasz ty mnie?

\section{JONATHAS}

O, mój ojcze! Kocham ciebie, ale kocham równie i sławę twoję. Ta jest przyczyna, że częstokroć, jak daleko synowi jest wolno, chcę odwracać uniesienia twoje.

\section{SAUL}

Ty często wstrzymywałeś rękę moję, ale to żelazo, którego mi w sercu zdrajcy nie dopuszczasz utopić, pamiętaj, że je obracasz przeciwko tobie samemu. — Ocalaj życie Dawida, a wkrótce... Czy nie słyszysz w głębi serca głosu wołającego na ciebie: „Dawid będzie królem” — Dawid królem! Niechaj raczej umiera pierwej. 


\section{JONATHAS}

A Pan Najwyższy nie wołaż do ciebie, ojcze, głosem daleko groźliwszym: „Dawid mi jest lubym, Dawid wybrańcem moim?” Wszystkie dzieła Dawida nie dowodząż widocznie, że on jest ukochanym od Boga? Jadowita nienawiść Abnera milczy na jego spojrzenie. Ty sam, mój ojcze, kiedy uniesienia twoje przemina, przyznajesz, że w przytomności jego wszystkie twoje podejrzenia niszczeja. Jakiż to duch ciemności zmysły twoje omamia? Rozumiesz więc, że to ja wstrzymuję ciebie? Ramię to Najwyższego wiąże twe ręce. Ledwo byś się ośmielił podnieść na Dawida żelazo ${ }^{91}$, a natychmiast moc niewidzialna zwróciłaby je ku tobie. Upadłbyś przed nim na kolana i łzami zalany żałowałbyś twego zapędu!... Tak jest, żałowałbyś zapewne, ojcze, bo nie jesteś bezbożnym. -

\section{SAUL}

Prawdę mówisz. Dawid jest dla mnie niepojęta istota. Kiedy go pierwszy raz ujrzałem w Ela" ${ }^{92}$, podobał się moim oczom, ale w głębi serca odzywał się wstręt jakiś ku niemu. W tych chwilach, kiedy się widzę skłonionym do kochania jego, uczuwam nieznajomy gniew, który mnie od niego odpycha. Częstokroć pragnę śmierci jego, ale gdy się pokaże, zmiękczony i zdziwiony jego wielkością widzę się poniżonym przed nim. Ten okropny stan duszy mojej jest skutkiem pomsty nieba; poznaję rękę, która ciąży nade mną!... Ale na próżno szukam przyczyny tego. Nie obraziłem ja nigdy Boga, jest to pomsta kapłanów jego. Dawid jest narzędziem ich zapalczywości. Widział w Rama ${ }^{93}$ umierającego Samuela, słyszał ostatnie słowa tego nieubłaganego starca. Kto wie, jeżeli ${ }^{94}$ Samuel nie oblał głowy jego olejem świętym, którym niegdyś namaszczał me czoło? Może... Czy nie wiesz co o tym?... Powiedz.

\section{JONATHAS}

Nic o tym nie wiem. Ale gdyby i tak było, nie jaż bardziej, niż ty, ojcze, powinien bym się tym obrażać? Nie jestemże pierworodnym twym synem?

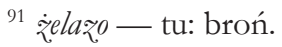

${ }^{92}$ Ela - zob. przyp. 45.

${ }^{93}$ Rama - zob. przyp. 14.

${ }^{94}$ ję̇eli — tu: czy.
} 
— Kiedy w czasie pójdziesz połączyć się z przodkami twoimi, nie dla mnież twój tron przeznaczyłeś? Jeżeli ja milczę, któż użalać się ma prawo? — Dawid przewyższa mnie w odwadze, w cnocie, w rozumie; im bardziej poznaję go wielkim, tym go więcej kocham. Jeżeli ręka, która daje i odbiera korony, uwieńczy nią skronie Dawida, uznam, że on jest jej godniejszym nade mnie. Bóg wzywa go, aby prowadził Izraela do najświetniejszych zawodów. — Z tym wszystkim przysięgam ci, mój ojcze, że Dawid jest najposłuszniejszym, najwierniejszym z twoich poddanych. Niechaj Najwyższy dokonywa wolę swoję, nie chciej powstawać przeciw niewzruszonym wyrokom jego. Gdyby Bóg sam nie przemawiał był przez usta Samuela, słaby ten starzec, na brzegu już grobu, mógłże by był tak świetną dla Dawida przepowiadać przyszłość? To samo zmieszanie nienawiści i szacunku, którego na widok zięcia twojego doznajesz, ojcze, ta bojaźń w chwilach bitwy; bojaźń nieznajoma dotąd walecznemu sercu twojemu... Ach! Któż z śmiertelnych zdoła się oprzeć mocy Najwyższego Pana?...

\section{SAUL}

Co mówisz? Jestżeś ty synem Saula, ty, który pogardzasz tronem? — Ale nie znasz ty, widzę, okrutnych praw przywłaszczyciela! - Cały mój dom zniszczonym będzie przez zdrajcę, który mi wydziera berło! Twoi bracia, dzieci, ty sam... Ach! Nie zostanie ani jedna gałązka z pokolenia mojego!... Nienasycona chuci panowania, cóż dla ciebie jest świętym? Dla przywłaszczenia tronu brat zabija brata, matka dzieci, żona męża i syn własnego ojca! Tron jest krwawym siedliskiem, na którym częstokroć zbrodnia zasiada.

\section{JONATHAS}

Jakaż broń ludzka pomstę Boga odwrócić jest zdolną? Upokorzenie, nie groźby błagają sprawiedliwość zagniewanego Pana, który wyniosłych poniża, a słabych wynosi. 


\section{SCENA IV \\ DAWNIEJSI, ABNER I ACHIMELECK}

\section{ABNER}

Królu, jeżeli powracam do ciebie wprzód, niżeli krew nieprzyjacielska zarumieniła tę ziemię, tedy ważny mnie tu powód sprowadza. — Nie znajduję nigdzie tego walecznego Dawida, który miał nam zapewnić zwycięstwo. Za godzinę wydajemy bitwę. Słyszysz, jak niecierpliwych twoich żołnierzy przeraźliwe krzyki napełniaja powietrze, jęczy ziemia pod nogami ich dzielnych rumaków, hełmy i zbroje błyszczą na wszystkie strony, a odgłos trąby dodaje odwagi najbojaźliwszym sercom. Dawida tylko nie widać, Dawida nigdzie nie znajduję. — Przypatrz się, królu, temu, który go zastępuje w obozie naszym, jego to mamy uważać jak pomoc nieba dla nas. Odziany białą szatą kapłanów, wkradł się w obwód naszych namiotów i znalazłem go drżącego pomiędzy Beniaminitami ${ }^{95}$. - Oto jest. Zapytaj go, dlaczego wystawia się na tak wielkie niebezpieczeństwo?

\section{ACHIMELECK}

Opowiem przyczynę, jeżeli mi król dozwoli tego. Jego gniew...

SAUL

Mój gniew?... A więc zasłużyłeś na niego? Ale któż jesteś? Zdaje mi się, że cię poznaję. Nie jestżeś ty jeden $z$ tych fałszywych proroków w Rama ${ }^{96} \ldots$

\section{ACHIMELECK}

Ja okryłem Ephodon ${ }^{97}$, jestem najpierwszym z Lewitów ${ }^{98}$. W długim najwyższych kapłanów następstwie, po szanownym Aaronie ${ }^{99}$, ja objąłem urząd

${ }^{95}$ Beniaminici - plemię wywodzace się od Beniamina, syna Jakuba i Racheli (Rdz 35,16-19). Zamieszkiwali ziemię Gibea (Sdz 9,16). Znani byli ze swojej ksenofobii (Sdz 19,15) oraz toczyli walki z Izraelitami, które zakończyły się ich klęską (Sdz 20, 14-48). Z plemienia Beniaminitów wywodził się król Saul (1 Sm 9,21).

${ }^{96}$ Rama - zob. przyp. 14.

${ }^{97}$ Ephodon — właśc.: efod, zob. przyp. 79.

${ }^{98}$ Lewici - zob. przyp. 110.

${ }^{99}$ Aaron - starszy brat Mojżesza i Miriam, syn Amrama i Jokebed. W czasie starań Mojżesza o wyzwolenie Izraelitów z niewoli egipskiej był jego rzecznikiem wobec faraona $\left(W_{j} 4,14\right)$. Po wyjściu z Egiptu był pomocnikiem Mojżesza i wraz z nim przewodził Izraelowi w walce z Amalekitami (Wj 17,8). Namaszczony na pierwszego arcykapłana Izraela (Kpł 8,1-36). Podobnie jak Mojżesz, nigdy nie wszedł do Ziemi Obiecanej. 
w świątyni Pana. W Nobbe ${ }^{100}$, stawam pierwszy przy Arce ${ }^{101}$. Ta święta Arka znajdowała się niegdyś pośród obozu Izraelitów; dziś i to jest za wiele, jeżeli który z kapłanów Najwyższego w nim się pokaże. Obcym jest namiestnik Boga, gdzie Saul panuje, nie powinien by jednak być nim w miejscu, gdzie się Izrael bije; jeżeli to prawda, że Bóg sam daje zwycięstwa... Ty mnie nie znasz; nie dziwuję się temu, ty nie znasz samego siebie. - Odwróciłeś kroki twoje od drogi pańskiej, ja jestem zawsze w świętym jego przybytku, a Saul już od dawna nie uczęszcza do niego. Noszę imię Achimelecka.

\section{SAUL}

Jest to nazwisko zdrajcy; teraz cię dopiero poznaję. Właśnie w czas widzę ciebie przed soba. - Nie ty że to jesteś, który Dawidowi dałeś przytułek, pożywienie i uzbroiłeś go orężem ${ }^{102}$ ? A jakim orężem? Oto wydartym Goliatowi, zawieszonym w przybytku Najwyższego, jemu samemu poświęconym, a który ty odważyłeś się wykraść świętokradzką ręką i powierzyć go nieprzyjacielowi twojego króla, twojego jedynego Pana? Przychodzisz teraz do obozu mojego, ażebyś mnie zdradził, nie ma w tym żadnej wattpliwości.

\section{ACHIMELECK}

Tak, przychodzę, ażebym cię zdradził, bo przychodzę błagać Boga o zwycięstwo, którego ci odmawia. — Tak jest, ja to podałem Dawidowi pomocną rękę, ale któż to jest ten Dawid? Nie jestże to mąż córki królewskiej? Najdzielniejszy z rycerzy? Najpiękniejszy, najmilszy, najsprawiedliwszy z dzieci Izraela? Któż wyrówna ${ }^{103}$ męstwu jego na wojnie? Kto w pokoju przyjemniej chwałę boską

100 Nobbe - zob. przyp. 77.

101 Arka — właśc.: Arka Przymierza; święta skrzynia, w której Żydzi przechowywali obiekty swojego kultu religijnego: laskę Aarona, dzban z manną i dwie tablice kamienne z wyrytym na nich przez Boga dekalogiem. Pierwszy raz w Biblii arka pojawia się po zawarciu przymierza pomiędzy Bogiem, a Izraelitami zmierzającymi do Ziemi Obiecanej (Wj 25-28). Była prostokatną skrzynią, noszoną za pomocą drewnianych drążków. Początkowo znajdowała się w „Namiocie Spotkania” (Wj 26,33), później przeniesiona została przez króla Salomona do świątyni jerozolimskiej (2 Krn 5,1-7). Arka zaginęła w trakcie najazdu armii Babilonu pod wodzą Nabuchodonozora II na Palestynę w 586 p.n.e. i zburzenia pierwszej świątyni. Nigdy nie wykonano jej na nowo.

102 oreż — broń, uzbrojenie.

103 wyrównać — tu: dorównać. 
śpiewać potrafi? Kochanie córek Syjonu ${ }^{104}$, pociecha ludu, postrach nieprzyjaciół... takim jest ten tułacz, któremu w ucieczce jego dałem schronienie. Ależ ty sam, czy nie wróciłeś ${ }^{105}$ mu dawnego dostojeństwa? Nie wybrałżeś go wodzem wojska, abyś sobie zapewnił zwycięstwo i oddalił z serca bojaźń, którą Bóg ukarał krnąbrność twoję? Jeżeli mnie więc obwiniasz, obwiniaj i siebie samego.

SAUL

Skądże wam przychodzi ta litość, wam, krwi zawsze chciwym potworom? Któż ty jesteś, zdradliwe plemię, które obok służby boskiej nosisz w sercu światowe widoki? Kiedy my krew przelewamy za was, wy w pokoju naśmiewacie się z niebezpieczeństw naszych? Bojaźliwi, słabsi od niewiast, chcecie rozkazywać rycerzom z bronią w ręku walczącym i pod nogi wasze zginać monarchów?

\section{ACHIMELECK}

A ty, czym jesteś? Królem ziemskim! Ale cóż jest król w obliczu Boga? — Saulu, zastanów się nad sobą. Nie jesteś nic więcej, tylko ukoronowany proch ziemi! Ja niczym jestem, ale kiedy Bóg wstępuje we mnie, staję się straszniejszym nad piorun. - Ten Bóg, który cię stworzył, woła przez usta moje: „Saulu! Saulu! Upamiętaj się!" On to sprzed oczu moich odsuwa zasłonę i pozwala mi widzieć przyszłe przeznaczenie twoje. Oto w ciemnym obłoku spostrzegam anioła śmierci, płomienistymi skrzydły unoszącego się nad tobą. Jedną ręką dobywa miecz zemsty, a druga porywa osiwiała w zbrodniach głowę twoję. - Drżyj, Saulu! Ten Abner, który stoi przed tobą, ten zaród duchów piekielnych, on cię wpycha do grobu. On to podejrzeniom otwiera zniewieściałe twe serce, on to wpaja królowi słabość lękliwego dziecięcia. - Nierozsądny! Wypędzasz z twojego dworu jedynego twojego obrońcę! Gdzież jest teraz dom Saula? Zbudował go na wodzie, zgniły posady jego, upadł i zaginął w błotnistych kałużach. -

\section{SAUL}

Ty przepowiadasz moje nieszczęścia, a nie przewidujesz twoich własnych. Nie spodziewałeś się zapewne wchodząc w ten obóz, że w nim śmierć twoję znaj-

104 Syjon - pierwotnie nazwa warowni na pd. Stronie wzgórza Ofel w Jerozolimie. Po sprowadzeniu arki przymierza przez Dawida oznaczał miejsce pobytu Jahwe (2 Sm 6,1-19). Po zbudowani świątyni jerozolimskiej przez Salomona, Syjonem zaczęto nazywać wzgórze świątynne (1 Krl 6,1-37), później samo miasto i jego mieszkańców. Stąd określenia typu: „córki Syjonu” (PnP 3,11), „,synowie Syjonu” (Lm 4,2).

105 wrócić - tu: przywrócić. 
dziesz! Otóż ja ci ją zwiastuję, a Abner uskuteczni tę wróżbę. — Idź, Abner, ty najpierwszy z krwi mojej, idź, odmień Dawida porządek boju, bo wszystko co on ułożył, jest zdradac. Jutro dopiero o wschodzie bić się będziemy; południowe słońce ma być świadkiem mego zwycięstwa i chwały! — Poznaję, że dlatego złośliwy Dawid wybrał wieczorną porę do bitwy, ażeby mi dał uczuć, że i ja zbliżam się już ku zachodowi. Ale zobaczy, czym Saul jeszcze być może! — Twoje groźby wznieciły moję odwagę, jutro sam będę wojsku memu przywodził; cały dzień nie wystarczy zawodom ${ }^{106}$, którem sobie ułożył. — Abner, oddal z oczu moich tego zdrajcę, niechaj natychmiast umiera...

\section{JONATHAS}

O Boże! Cóż chcesz czynić, mój ojcze?

\section{SAUL}

Milcz!... Niechaj zamordują Achimelecka, a krew jego niechaj spadnie na Filistynów.

\section{ABNER}

Umrze natychmiast.

\section{SAUL}

Ale krew jego nie nasyci jeszcze mej zemsty! Poślij do Nobbe ${ }^{107}$ wyrok śmierci dla wszystkich. Niechaj zabijają niewiasty, dzieci, niewolników i trzody; niechaj potem spalą wszystko wraz z ich domami, a obmierzłe ich popioły niech rozrzucą na wszystkie wiatry! Ręka moja, tylekroć pociagana do zemsty przez zbrodnie wasze, ochraniała was dotąd; pogardzaliście przeto potęga moja, ale teraz tym ogromniej uderzy! Będzie świat mógł ze strachem wspominać: „Był kiedyś Saul”.

\section{ACHIMELECK}

Żaden król nie może mi zabronić umrzeć śmiercią sprawiedliwych, zgon więc mój miłym dla mnie i chwalebnym będzie! — Nieubłagany w gniewie Pan Najwyższy, dawno już ciebie i Abnera wskaza1 ${ }^{108}$ na śmierć nikczemna, ale nie przez żelazo nieprzyjaciół waszych. - Idźmy. Ostatni raz dałem słyszeć bezbożnemu głos Boga, ale on jest głuchym i zapamiętałym w swych zbrodniach. — Dopełniłem powinności kapłana, godnie więc spełniłem ostatek dni życia mojego. -

\footnotetext{
${ }^{106}$ zawód - tu: przedsięwzięcie, działanie, czyn.

${ }^{107}$ Nobbe - zob. przyp. 77.

${ }^{108}$ wskazać - tu: skazać.
} 
SAUL

Niechaj go prowadzą na śmierć i niech mu zadadzą męki długie i najokropniejsze. -

\section{SCENA V \\ SAUL, JONATHAS \\ JONATHAS}

Nieszczęśliwy królu! Co czynisz? Zatrzymaj się!

SAUL

Puszczaj mnie, ostatni raz ci mówię. Jestżeś ty rycerzem? Jestżeś ty synem moim i krwi twojej godnym? Nie. — Idź raczej do Nobbe ${ }^{109}$. — Weź urząd Achimelecka; ty powinieneś żyć między próżniackimi Lewitami ${ }^{110}$, ale nie wpośród szczęku orężów, nie na pałacu królewskim...

\section{JONATHAS}

Przy twoim boku gromiłem nieraz nieprzyjaciól. - Krew, którą dziś przelewasz ojcze, nie jest to krew Filistynów ${ }^{111}$, ale krew bezbronnego kapłana. W tak wielkim niebezpieczeństwie, ty tylko sam...

\section{SAUL}

Gardzę każdym niebezpieczeństwem, brzydzę się życiem moim. Nikczemny, jeżeli się lękasz, nie wychodź do jutrzejszej bitwy. Ja sam tam będę. — Na co mi Jonathas, na co mi Dawid, dosyć tam na mnie samym będzie. -

${ }^{109}$ Nobbe - zob. przyp. 77.

${ }^{110}$ Lewici — plemię wywodzące się od Lewiego, syna Jakuba i jego pierwszej żony Lei (Rdz 29,34). Lewi razem ze swoim bratem Symeonem zostali przeklęci za zdradziecki napad na Sychem. Pokolenie Lewiego rozproszyło się po Izraelu i zniknęło jako społeczność świecka; dopiero później zaczęli pełnić funkcję religijną. (Rdz 49,3). Ich miasta miały charakter typowo sakralny i wyłącznie Lewici mieli w nich zapewnione stałe prawa (Kpł 25,32). Odpowiadali za opiekę nad Świętym Przybytkiem (Lb 1,50). Niektórzy pełnili również służbę urzędniczą i wojskową.

${ }^{111}$ Filistyni - zob. przyp. 3. 


\title{
JONATHAS
}

Ja obok ciebie walczyć nie przestanę. - Obym padł trupem w oczach twoich pierwej, niżeli zobaczę spełnione przeznaczenia nieszczęśliwej rodziny mojej.

SAUL

Cóż mi pozostaje na świecie? Śmierć. Znajdę ją w boju godną wielkości mojej.

\section{SCENA VI \\ DAWNIEJSI I MICHOLA \\ SAUL}

Przychodzisz bez Dawida?

\author{
MICHOLA
}

Nie mogłam go znaleźć.

\section{SAUL}

Znajdę ja jego.

\section{MICHOLA}

Już może jest daleko. Ucieka przed twoim gniewem.

SAUL

Gniew mój ma skrzydła, które go dościgną. Biada Dawidowi, jeżeli go zobaczę wśród bitwy; biada tobie, jeżeli po mojej wygranej nie stawisz go przede mną. -

$$
\text { MICHOLA }
$$

O Boże!

Ach, ojcze mój!

$$
\text { JONATHAS }
$$

SAUL

Już nie mam dzieci. Uciekaj, uciekaj daleko ode mnie, Jonathas. — A ty, szukaj i wynaleź ${ }^{112}$ Dawida.

\footnotetext{
112 wynaleźc — tu: odnaleźć.
} 


\title{
MICHOLA
}

Chcę przy tobie, ojcze, pozostać!

\author{
SAUL
}

Nie. Nie chcę cię widzieć.

$$
\text { JONATHAS }
$$

Ja miałbym z daleka od ciebie walczyć?

SAUL

Oddalcie się wszyscy ode mnie, wy mnie wszyscy zdradzacie. Wychodźcie, tak chcę, rozkazuję wam. -

\section{SCENA VII}

SAUL

sam

Jestem teraz sam z sobą... Nieszczęśliwy!... Teraz nawet samego siebie lękać się muszę!

\section{rzuca sie na skate}

Koniec aktu czwartego

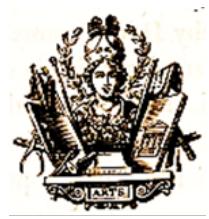




\section{AKT V \\ SCENA I \\ DAWID, MICHOLA}

\section{MICHOLA}

Wyjdź, najmilszy małżonku, wyjdź, noc już jest ku połowie... Czy słyszysz ten szmer w obozie? Bitwa ma się zaczać o samej jutrzence. — Głuche milczenie panuje wokoło namiotu mojego ojca, widzisz; niebo samo ułatwia nam ucieczkę. Księżyc zachodzi, a ostatnie promienie jego czarne zakrywaja chmury. Idźmy, nikt nas widzieć nie może; oddajmy się opiece Najwyższego i spuśćmy się $^{113}$ na dolinę z tej góry. -

\section{DAWID}

Micholo! Ty najzacniejsza cząstko mnie samego, chceszże, ażeby Dawid zamyślał ${ }^{114}$ o ucieczce w ten czas, kiedy Izrael gotuje się do bitwy? Nie lękam ja się śmierci, zostanę. Saul może mnie wydać na zgubę, jeżeli zechce; śmierć przyjemną mi będzie, bylem pierwej okrył pole trupami nieprzyjaciół jego.

\section{MICHOLA}

Ach! Ty nie wiesz, co się tu stało! Mój ojciec już zaczął przelewać krew dla nasycenia swojego gniewu. Achimeleck, którego znaleziono w tych miejscach, stał się pierwszą ofiarą zapalczywości jego!

\section{DAWID}

Co słyszę! On się odważył kazać zabić kapłana pańskiego! Nieszczęśliwy Saulu!

\section{MICHOLA}

Nie na tym koniec. Król sam rozkazał Abnerowi zwrócić przeciwko tobie oręż Izraela, gdybyś się pokazał w tej bitwie.

\section{DAWID}

A mój najżyczliwszy Jonathas pozwolił na to!

113 spuszczać sie - schodzić.

${ }^{114}$ zamyślać — powziąć myśl, zamierzać, planować. 


\section{MICHOLA}

Cóż on może? I on doznał gniewu mojego ojca; teraz rozpacz sama prowadzi go do boju, ażeby tam śmierć prędką znalazł. Widzisz tedy, że tu zostać nie możesz. Trzeba ustapić burzy, uciec potrzeba i czekać, póki mój ojciec nie odmieni zdań swoich albo nie upadnie pod ciężarem staro<śs $>$ ci. - Ojcze okrutny! Ty sam przymuszasz nieszczęśliwą twoję córkę do pragnienia dnia okropnego... Ale nie, nie chcę śmierci twojej, żyj raczej, żyj szczęśliwy, jeżeli nim być możesz; mnie dosyć na tym, że się odtąd nie rozłączę z mężem... Pójdź ze mną... Idźmy...

\section{DAWID}

O jak żałuję, że muszę opuszczać tę bitwę! Słyszę nieznajomy głos wołający w mym sercu: „Ostatni już dzień przyszedł dla Izraela i dla króla jego!” O, gdybym mógł!... Ale nie. Tu przelano krew kapłana świętego, nieczystym jest ten obóz, ziemia ta jest zmazaną, Bóg ją wyklął. Dawid nie powinien wojować w tych miejscach. — Muszę więc ustąpić twojej bojaźni i twojej miłości. - Ale i ty chciej ustapić mojej, opuść mnie. -

\section{MICHOLA}

Jażebym cię opuścić miała? Na krok nie odstapię od ciebie, nikt mi cię wydrzeć nie potrafi.

\section{chce odejsć, ciagnac go za soba}

\section{DAWID}

Zaczekaj; twe drżące kroki nie wydołają szybkiemu biegowi mojemu. Ponieważ tak chcesz, muszę więc dla ochrony życia mojego przebiegać góry cierniami zarosłe. Jakże twoje delikatne stopy unieść cię po nich zdołają Przez opóźnienie, które byś w ucieczce mojej sprawiła, wkrótce by mnie schwytano. Przywleczono by nas oboje przed króla, a wystawieni na okropny gniew jego... O Boże! Ta sama myśl dreszcz we mnie sprawia!... A gdyby nawet potrafiliśmy złości jego uniknacć, mamże pozbawiać twojej pomocy nieszczęśliwego i cierpieniem obarczonego ojca? Oddalony od swojego domu nieszczęściami wojny, potrzebuje pomocy i pociechy twojej. Zostań przy nim, uspokajaj jego boleści, ocieraj łzy jego. Ty sama tylko służysz mu, przynosisz ulgę i utrzymujesz opłakane dni jego. On pragnie mej śmierci, a ja pragnę, ażeby żył szczęśliwy i triumfujący... Dziś jednakże lękam się o niego. Micholo, zaklinam cię, nie 
chciej powiększać zgryzot ojca, dosyć i tak udręczonego; pamiętaj, że wprzód byłaś córką aniżeli małżonka, nie jest ci wolno kochać mnie więcej, niżeliś powinna. - Chcę się uchronić od niebezpieczeństwa, cóż możesz więcej żądać ode mnie? Jak tylko stanę w miejscu mojego wygnania, uwiadomię ${ }^{115}$ cię zaraz. Wkrótce połączymy się znowu, tak się spodziewam. Czujesz zapewne, jak to rozłączenie jest bolesnym dla mnie... Ale...

\section{MICHOLA}

Nieszczęśliwa, mamże cię znowu utracić? Chcesz, ażebym ci dozwoliła błąkać się samemu od jednej do drugiej jaskini? Ach! Gdybym przynajmniej w tym opłakanym i niebezpiecznym życiu towarzyszyć ci mogła!... Dzieląc twe bóle, znośniejszymi bym je czyniła!

\section{DAWID}

Zaklinam cię przez miłość naszę, a jeżeli tak chcesz koniecznie, rozkazuję ci jako mąż, nie chodź za mną. Gdybyś stąd poszła, i mnie i ojcu stałabyś się przyczyną okropnych nieszczęść. - Ale ponieważ Bóg każe, abym się oddalił, nie należy dłużej odwłóczyć. Dzień się zbliża; mógłby mnie kto zoczyć116 i wydać. Znam ja doskonale tych gór manowce ${ }^{117}$, jestem pewny, że uniknę przed wszystkich wzrokiem. — Uściskaj mnie po raz ostatni! — Niechaj Bóg będzie z tobą! Zostań przy twoim ojcu, póki Najwyższy nie połączy cię z twoim mężem. -

\section{MICHOLA}

Po raz ostatni!... I ty chcesz, ażebym żyła!... Rozdzierasz me serce...

\section{DAWID}

Czyliż moje mniej cierpi?... Otrzyj te łzy... Potężny Boże! Dodaj skrzydeł ucieczce mojej!

\section{wybiega}

115 uwiadomić - oznajmić, dać wiadomość, donieść.

${ }^{116}$ zoczyć — właśc.: zobaczyć.

${ }^{117}$ manowiec — bezdroże, wertep, wybój. 


\section{SCENA II \\ MICHOLA}

sama

Ucieka?...Ach! Pójdę za nim. — Ale jakież mnie więzy zatrzymują? Nie mogę się stąd oddalić, nie mogę pójść za nim. - Wydarł się z rąk moich, utracam ${ }^{118}$ go znowu!... Kiedyż go zobaczę? — Nieszczęśliwa żono, takież to szluby, takież to twoje małżeństwo! — Nie, nie chcę dłużej pozostać przy ojcu okrutnym, pójdę za Dawidem. - Ale mamże zostawić zgrzybiałego starca bez żadnej pomocy? — Cóż to jest?... Słyszę okropny szczęk broni!... Coraz bardziej się zbliża... odgłos trąby z nim się połącza... ziemia drży pod tętentem koni... Cóż znaczy ten tumult ${ }^{119}$ ? — Saul dopiero przed wschodem słońca nakazał bitwę. - Może bracia moi... może Jonathas jest w niebezpieczeństwie! - Cóż to za okropny krzyk, co za jęki wychodzą z namiotu mojego ojca?... Nieszczęśliwy!... Bieżmy do niego. — Otóż i on sam. — Boże! W jakimże widzę go stanie! — Ach! Ojcze mój! —

\section{SCENA III \\ SAUL, MICHOLA \\ SAUL \\ w obtakaniu}

Duchu zagniewany, zatrzymaj się, puszczaj mnie... padam na kolana przed tobą. - Dokąd uciec? Gdzie się ukryć?... Uspokój się, straszliwy duchu!... Ale on głuchym jest na prośby moje. - Ziemio, rozstąp się, po $<\dot{z}>$ rzyj $^{120}$ mnie żywego w wnętrznościach twoich, bylem schronił się przed okropnym wzrokiem, jakim na mnie ten duch spogląda...

\section{MICHOLA}

Przed kimże uciekasz?... Nikt cię nie goni, mój ojcze. Czyliż mnie nie widzisz? Nie poznajesz mnie?

118 utracaí — właśc.: tracić.

119 tumult — zamęt, zgiełk, wrzawa.

${ }^{120}$ po żrzéc - pożreć. 


\section{SAUL}

Najwyższy kapłanie Izraela, czy chcesz abym tu pozostał? Samuelu! Ty, który byłeś drugim ojcem moim, rozkazujesz to? Poddaję się twym najwyższym wyrokom. - Ty niegdyś uwieńczyłeś czoło moje koroną, zedrzyj ją teraz i rzuć pod nogi twoje... Ale co widzę?... Miecz ognisty nad moja głową!... Nie odwracaj go, Samuelu, ode mnie, ale odwróć go od dzieci moich... Dzieci moje nie są winne mych zbrodni.

\section{MICHOLA}

Co za okropne obłąkanie! — Ojcze mój, nie jesteś przy zmysłach... Obróć na mnie twe oczy.

\section{SAUL}

O pociecho!... Spokojność jest na twojej twarzy. Nienawistny starcze, dajesz się przecięż poruszyć prośbom moim?... Nie puszczę się twych kolan, póki nie odwrócisz od dzieci moich pomsty nieba. — Cóż to mówisz? — „Dawid był także twoim synem, prześladowałeś go, rozkazałeś, ażeby umarł!” Ach! Czekaj, wstrzymaj zapalczywość... Gdzie jest Dawid? Niech go szukaja, niechaj powróci, niechaj mnie zabiją na jego miejscu, a on niechaj panuje; niech panuje, byle miał litość nad moimi dziećmi!... Ach! Ty jesteś nieubłaganym! Oczy twoje zakrwawione... miecz twój gorejący!... Ogień z ust twoich wybucha... tchniesz na mnie samym płomieniem... już mnie ogarnia; pożera mnie!... Dokąd uciec?... Ach! Ukryję się w tę stronę.

\section{MICHOLA}

Nie potrafięż, mój ojcze, ani zatrzymać ciebie, ani odwrócić tych próżnych marzeń? Posłuchaj mnie. Jesteś tu...

\section{SAUL}

Nie, tą stroną przejść niepodobna... Szeroka, krwią płynąca rzeka wstrzymuje mnie... Co za widok okropny! Trupy świeżo pomordowanych, jeden na drugim, stosami leżą na brzegu... tam już wszystko wymarło! — Pójdę więc tędy... Co widzę? Kto wy jesteście? — „Widzisz przed tobą synów Achimelecka, a ja jestem sam Achimeleck! Umieraj Saulu! Umieraj!” Cóż to za głos? - Poznaję go... Zbroczony krwią świeżo przeze mnie rozlaną chce się teraz moją nasycić. - Ale któż z tyłu porywa mnie za włosy?... Ach! To Samuel!... 
Co mówisz? Że wkrótce będę już z tobą? — Tak, ja sam będę z Toba, ale te niewinne dzieci. — Gdzież jestem?... Znikły wszystkie mary. — Jakiż to odgłos uderza uszy moje? To jest wrzask bitwy, a słońce jeszcze nie weszło!... Tak, to są krzyki walczących!... Niechaj mi podadzą zbroję, mój hełm, mój oręż $\dot{z}^{121}$, chcę umierać na polu bitwy.

\section{MICHOLA}

Co czynisz, ojcze? Uspokój się. Córka twoja...

SAUL

O jakiej mi córce wspominasz? Ja chcę zbroi, niechaj mi ją natychmiast podadza.

$$
\text { MICHOLA }
$$

Nie odstapię ciebie.

\section{SAUL}

Odgłos trąby coraz bardziej się wzmaga. Mój miecz wystarczy mi do boju. Puszczaj mnie, bądź posłuszną. Idę w tę stronę, tam jest śmierć, tam ją chcę znaleźć.

\section{SCENA IV}

DAWNIEJSI, ABNER Z ORSZAKIEM UCIEKAJĄCYCH IZRAELITÓW ABNER

Nieszczęśliwy królu! Dokąad idziesz?... Ta noc jest straszliwą dla ciebie!

SAUL

Dlaczegóż wydano bitwę?

\section{ABNER}

Nieprzyjaciel pierwszy uderzył na nas. Zwyciężeni jesteśmy, pobici zupełnie.

SAUL

Zwyciężeni? A ty, nikczemny, żyjesz jeszcze?

${ }^{121}$ oręż - broń, uzbrojenie. 


\section{ABNER}

Żyję, ażebym ciebie ratował. Filistyni ${ }^{122}$ otoczyli te miejsca, unikać potrzeba ich spotkania. Z tym wybranych orszakiem przeprowadzę ciebie...

SAUL

Jak mam żyć, kiedy mój naród ginie?

\section{MICHOLA}

Ach? Ojcze... wrzask się powiększa... zbliżają się ku nam...

\section{SAUL}

Jonathas!... Dzieci moje, wszyscy uciekli, wszyscy mnie opuścili!

\section{ABNER}

O Boże!... Dzieci twoje nie uciekały!... Nieszczęśliwi!...

\section{SAUL}

Rozumiem cię. Poginęli wszyscy!

\section{MICHOLA}

Niestety! Bracia moi...

\section{ABNER}

Nie masz już żadnego syna.

\section{SAUL}

Cóż mi więc pozostaje na świecie? - Ty sama tylko, córko moja; ale nie chcę ażebyś los mój dzieliła ze mną. — Już od dawna ułożyłem w mej duszy, co mam dokonać. — Przyszła już chwila... Abner, słuchaj ostatniego mego rozkazu. Ukryj w bezpiecznym miejscu córkę moję.

\section{MICHOLA}

Nie, mój ojcze, ja cię moim ciałem zasłonię; nieprzyjaciel nie będzie śmiał uderzyć niewiasty.

\section{SAUL}

Wstrzymaj się, córko, i nie wyciskaj łez moich. Zwyciężony król nie powinien płakać. Abner, ukrywaj ją a jeżeli by wpadła w ręce nieprzyjaciół, nie wyjawiaj,

\footnotetext{
${ }^{122}$ Filistyni-zob. przyp. 3.
} 
że jest córką Saula; powiedz im, że ona jest żoną Dawida, a szanować ją będą.

— Idź, uciekaj. —

\section{ABNER}

Ocalę ją, przyrzekam ci to królu. Ależ ty sam...

\section{MICHOLA}

Ojcze! Nie potrafię cię odstapić.

\section{SAUL}

Ja tak każę, wszak jeszcze królem jestem. — Nieprzyjaciel się zbliża. — Uciekaj Abner, a jeżeli koniecznie trzeba, gwałtem córkę moję wyprowadź.

\section{Abner wyprowadza Michole i odchodzi zorszakiem \\ MICHOLA}

Ojcze! Żegnam cię na wieki!

\section{SCENA OSTATNIA}

SAUL

O dzieci moje!... Ach! Już nie jestem ojcem! — Zostałeś tedy sam, o królu! Z tylu przyjaciól, z tylu podchlebców ${ }^{123}$, którzy dzielili pomyślność twoję, nie pozostał ci ani jeden niewolnik! Nieprzebłagane nieba! Czy niedosyć pomsty już macie? - Ale zostało mi jeszcze żelazo, to w tej chwili odda mi ostatnią usługę. - Słyszę wrzaski zuchwałych zwycięzców, ich gorejące pochodnie, ich miecze błyszczą w mych oczach! — Pokolenie bezbożne! Znajdziesz mnie, ale zabitego mą ręką... poznasz, że umiem jak król umierać.

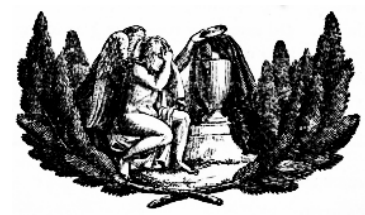

KONIEC TRAGEDII

${ }^{123}$ podchlebca — właśc.: pochlebca. 



\section{UWAGI NAD SAULEM}

Wysokie, a przyjemne piękności Biblii, których nauka najulubieńsza była Alfieriemu, podały mu zapewne myśl ułożenia tragedii Saula. Ta poetyczna uroczystość stylu, ta prostota prawdy, jakich Pismo Święte jest pełnym, różni tę sztukę od wszystkich innych dzieł jego. Obraz, który on widzom przedstawia, jest to król pogardą obrządków Mojżesza, zniewagą kapłaństwa i okrucieństwy nad ludem, ściągający na siebie pomstę Boga. Jest on takim, jakim go Bossuet ${ }^{1}$ maluje, kiedy mówi o jego zwycięstwach, dumie, nieposłuszeństwie, a na koniec upadku i zgonie. (a)

Wierny raz przyjętym dramatycznej sztuki zasadom Alfieri, wszystkich w tym dziele dopełnia. - Jedność czasu nie przechodzi dwudziestu czterech godzin; rzecz bowiem zaczęta o świcie, kończy się tego samego dnia po zachodzie słońca. - Jedności miejsca dowodzi ten sam zawsze obóz, pokazujący się przed namiotem Saula. - Osnowa rzeczy jest jedna, niepodzielna, ten sam zawsze przedmiot wystawiająca. Od samotnej rozmowy Dawida w pierwszej scenie, aż do ostatnich słów tragedii, wszystko tyczy się Saula, wszystko się do niego samego ściaga ${ }^{2}$. - Wprowadzenie rzeczy (b) jest wzorem doskonało-

(a) Discours sur l'bistoire universelle. (przyp.aut.). Tytuł dzieła w przekładzie polskim brzmi: Dyskurs o bistorii powszechnej.

${ }^{1}$ Bossuet - właśc. Jacques-Bénigne Bossuet, ur. 27 IX 1627 w Dijon, zm. 12 IV 1704 w Paryżu, kaznodzieja, biskup, pisarz i teolog francuski. Obrońca katolicyzmu, doskonały orator, twórca „elokwencji naturalnej” — (stylu złożonego z zarówno z elementów wzniosłych, jak i prostych). Od 1671 roku członek Akademii Francuskiej. Poglądy filozoficzne zawarł w dziele Traité de la connaissance de Dieu et de soi-même; rozwiną tu tezę o celowym rozwoju historii zgodnie z planem bożym i nadprzyrodzonym pochodzeniu władzy królewskiej; propagował też absolutyzm. Jego koncepcje i poglądy spotkały się z krytyką filozofów oświecenia, gł. Woltera.

(a) Ekposycja (przyp. aut.); tu: początek inscenizacji.

2 ściagać - tu: sprowadzać. 
ści. Kilka wierszy Dawida w pierwszej scenie uwiadamiają słuchacza o całym jego przeznaczeniu. W drugiej, Jonathas wystawia ${ }^{3}$ położenie wszystkich w tę sztukę wchodzących osób. Nie ma tu żadnego powiernika, żadnych długich opowiadań. Żadna scena nie jest zbyteczna, żadnej nie brakuje do zupełności rzeczy. Wchody i wychody osób nie są bez przyczyn, a podziały aktów wypadają tam, gdzie być koniecznie powinny. - Co do obyczajów, czyli charakterów osób, te są zawsze i ciagle niezmienne. Saul, chociaż już obarczony zemsta Boga, zawsze jest okrutnym, dumnym, nienawidzącym proroków; a pomimo te występki, zawsze wielkim i mężnym rycerzem, zawsze czule kochającym dzieci swoje ojcem. - Dawid, pełen cnoty szlachetności i męstwa, znosi zawsze w pokorze krzywdy wyrządzane od Saula; zawsze unika od niego, nie z bojaźni, ale aby nie dał zapalczywemu królowi powodów do popełnienia, przez wydarcie mu życia, większych jeszcze zbrodni. - Michola, wzór niewinności, niezachwianej miłości dla męża, miłości dziecinnej ku ojcu, cierpliwości i ufności w Bogu wystawia obraz cnot patriarchalnych. - Jonathas szanuje zawsze ojca, ale wstrzymuje uniesienia jego; kocha zawsze Dawida, bo w nim przewiduje zbawienie Izraela. - Achimeleck, wystawia wysoką godność kapłana, napominającego w imieniu Boga występnego króla. Dowodzi tej wielkości w samej nawet odwadze, z jaką idzie na męki. - Abner, chociaż podżegający ${ }^{4}$ nienawiść Saula, nic podłego nie wystawia patrzącym. Zawiść, która on ku Dawidowi czuje, jest skutkiem przekonania o własnej zdolności. Jest on z krwi Saula, jest równie odważnym, jak doświadczonym wodzem; okazuje to ułożony przez niego plan bitwy, przez samego Dawida przyjęty. Słusznie więc zazdrości wyniesieniu Dawida, które stawa na przeszkodzie jego zasługom. Wymowa i styl, które w przekładaniu z wiersza na prozę wiele stracić koniecznie musiały, są zawsze zwięzłe, pełne mocy, ognia i głębokich myśli, jednej z drugiej wypływających. A co nad wszystko wielkiego sztuki dramatycznej znawcę w Alfierim okazuje ${ }^{5}$, jest to stopniowanie namiętności, które przedstawiającemu artyście dziwnie grę ułatwiając, coraz mocniej zachwyca patrzących i podług woli autora wzbudza w nich litości, przestrachu, a na koniec okropności uczucia. Na dowód tego rozważmy główną osobę Saula.

\footnotetext{
${ }^{3}$ wystawiać - tu: ukazywać, uwidoczniać.

${ }^{4}$ podżegać — wzbudzać gniew, nienawiść.

${ }^{5}$ okazywać - tu: przedstawiać, pokazywać.
} 
Za pierwszym wstapieniem jego na scenę, nie widzą w nim patrzący jak tylko niespokojność, smutek i tęsknotę. Użala się nad sobą samym, przypomina dawną wielkość swoję. - Niespodziewane zjawienie się Dawida rodzi w nim gwałtowniejsze uczucia. Gniew, zazdrość, pycha wioda go do wyrzucenia Dawidowi zdrady i czuwania na życie jego. - W czasie przedziału między drugim i trzecim aktem, poduszczenia ${ }^{6}$ Abnera wzbudzają w nim jeszcze sroższe wzruszenia. Wychodzi na scenę pełen dręczących go wyobrażeń. Zdaje mu się, że widzi śmiertelne mary. Szuka Dawida, kapłanów, ołtarza; rośnie w nim zapalczywość, ale nie dochodzi jeszcze do ostateczności, bo ta dopiero powinna stanowić los jego. Śpiewy Dawida przypominające królowi jego dawna wielkość, uśmierzają na chwilę uniesienia, ale jedno wspomnienie o „drugim mieczu”, mogącym obok niego zwyciężać na polu sławy, powraca mu dawna zapalczywość. Szuka oręża, chce zabić Dawida, a choć zatrzymany na chwilę przez dzieci, powraca w czwartym akcie w większym jeszcze zapale. Pierwsze jego zapytanie: „Gdzie jest Dawid?” oznacza nieposkromiony gniew jego. W powiększającej się zapalczywości gromi córkę, ociąającą się w szukaniu Dawida, znieważa syna, a pokazanie się w obozie Achimeleka, przypomina mu wszystkie jego nieszczęścia. To wzbudza w nim najsroższą zapalczywość, okrucieństwo i wściekłość. Skazuje na męki kapłana, daje wyrok śmierci na całą krainę Nobbe, odpędza własne dzieci i na koniec sam sobą się brzydzi! Po tych najsroższych namiętnościach, jakie tylko człowiekiem miotać moga, zdawałoby się, że już nic okropniejszego ani czuć, ani wystawić nie można nie tak sądził Alfieri, który głęboką serca ludzkiego posiadał znajomość. Cóż sroższego nad zgryzoty sumienia? Co okropniejszego nad widok pomsty zagniewanego Boga? - Nieszczęśliwy Saul pokazuje się w ostatnim akcie, obłąkany, w przestrachu, w rozpaczy! Jego okropne uczucia są narzędziem męczarni, już nie dla drugich, ale dla niego samego! Zdaje mu się widzieć nad głową anioła śmierci, stawa przed nim znieważony Samuel, zamordowany Achimeleck! Słyszy i powtarza ich groźby! Otaczaja go siarczyste płomienie... ucieka... ale każdy krok jego wstrzymuje nowy widok popełnionych zbrodni!... Tu stosy pomordowanych... tam rzeka krwia płynąca... w obłokach Samuel chwytający go za włosy!... — „Co mówisz, Samuelu?”, pyta przestraszony — „Że ja będę dziś z tobą? Tak, ja sam będę z tobą, ale te niewinne

${ }^{6}$ poduszrçenie — namowa do czegoś, zwłaszcza złego. 
dzieci" - wspomnienie ukochanych dziatek, ostatniej w tym życiu pociechy, wyciska łzy boleści z oczu i odbiera mu mowę... Jakież słowa wyrazić by zdołały tę walkę, którą wszystkie razem namiętności wiodą w sercu Saula w tej chwili!... Najwyższy triumf sztuki autora, najwyższa sztuka artysty, umiejącego wystawić to wymowne milczenie! - Ale cóż obudzi na nowo zapalczywość Saula, która by go aż do zadania sobie śmierci przywiodła? Oto odgłos traby wojennej przypominającej mu bliska zgubę Izraela! Szuka zbroi, spieszy na pobojowisko... ale zachodzi mu drogę Abner donoszacy o przegranej bitwie i utracie wszystkich synów jego!... Po tym ostatnim ciosie kary boskiej, cóż mu pozostaje na świecie? Śmierć; ale śmierć chwalebna, śmierć jaka królowi przystoi. Na próżno Abner usiłuje skłonić go do ucieczki. „,a mam żyć, kiedy mój naród ginie?” Taka jest odpowiedź Saula — dobywa miecza, spieszy na pole bitwy... Mnóstwo otaczających nieprzyjaciół zatrzymuje go... nie ucieka, ale wielki i w ostatniej swej chwili „pokolenie bezbożne, poznasz, że umiem jak król umierać" — woła grożącym jeszcze głosem... i rzuca się na własny oręż. —

Wszystkie sztuki Alfierego pełne wysokich piękności w każdym rodzaju, mają swoje uchybienia i wady. Znajdują się one może i w Saulu, ale moim zdaniem tragedia ta, pod względem dramatycznej sztuki uważana jest z dzieł jego najdoskonalszym.

Francuski tłumacz sztuk Alfierego Pan Petitot, który w każdej krytyce swojej daje poznać niechęć, jaką czuł ku Alfieremu z powodu różnicy w zdaniach politycznych; przyznając mu wiele z wymienionych wyżej piękności, powiada, że mało znany autor francuski Duryer ${ }^{7}$, doskonalej wystawił w swojej tragedii osobę Saula. „Król ten” - mówi Pan Petitot — „obarczony pomstą Boga, znosi ją w upokorzeniu i cierpliwie. Kiedy mu duch Samuela zwiastuje, że utraci tron, życie i wszystkie dzieci, nieszczęśliwy Saul płacze i bez szemrania poddaje się wyrokom nieba". - Podobne zdanie samo z sobą jest sprzeczne. Jeżeli bowiem Saul był zawsze dumnym, okrutnym i na głos Boga niedbałym, był nim niezaprzeczenie i w czasie upadku swojego, bo napominania i groźby Samuela oraz innych kapłanów dowodza krnąbrności jego. Jeżeli zaś równie w pomyślności jak i w nieszczęściu był pokornym, cierpliwym i zgadzającym się z wolą najwyższego Pana, tedy napominania go i groźby były niepotrzebne, a pomsta Boga, nie zgadzałaby się z nieskończoną dobrocią i sprawiedliwością jego. - Saul więc Alfierego jest takim, jakim być powinien; jakim go Pismo Świete wystawia.

\footnotetext{
7 Duryer — właśc. Pierre Du Ryer; tragediopisarz, autor Saula (1639-1640).
} 




\section{APARAT KRYTYCZNY}

W Aparacie krytycznym nie sygnalizowano zabiegów polegających na poprawianiu drobnych oczywistych opuszczeń znaków diakrytycznych. Zamieszczono tu natomiast informacje o decyzjach wydawniczych, polegających głównie na wprowadzeniu poprawek, mających na celu uzyskanie właściwej formy wyrazu.

Podstawa wydania: Bogusławski W., Saul, [w:] idem, Drieła Dramatyczne, t. 1, Warszawa 1820, s. 1-84 (DD).

s. 79 zgina $<\hat{c}>-$ popr. wyd.; zginqé - DD (bł. druk.)

s. 84 Osta $<t>$ nie — popr. wyd.; Ostanie — DD (bł. druk.)

s. 91 nie $c h<c>e-$ popr. wyd.; nieche - DD (bł. druk.)

s. $93 w$ Dawidz $<i>e$ — popr. wyd.; $w$ Dawidze — DD (bł. druk.)

s. 97 mo<j>ego — popr. wyd.; moego — DD (bł. druk.)

s. 100 nie $<$ z $>$ dobyte — popr. wyd.; niedobyte — DD (bł. druk.)

s. 111 Moa $<b>$ — popr. wyd.; Moak — DD (bł.)

s. $111 E d o<m>a$ - popr. wyd.; Edona - DD (bł.)

s. $112 W<s>$ sytka $a$ popr. wyd.; $W_{\text {syytka }}$-DD (bł. aut.)

s. $116<S A U L>$ — popr. wyd.; DAWID — DD (bł. aut.)

s. 127 staro $<\dot{s}>c i-$ popr. wyd.; staroci - DD (bł. druk.) 


\section{SPIS RZECZY}

Wstęp.................. 5

Vittorio Alfieri - droga życia i twórczości autora oryginału tragedii Bogusławskiego................. 7

Teatr Narodowy na wygnaniu................ 17

Losy Saula na tle dziejów Izraela w ujęciu biblijnym i literackim................ 23

Saul. Analiza i interpretacja sztuki............... 33

Przekazy Saula. Rekonesans badawczy............... 47

Zasady opracowania edytorskiego................ 61

Wykaz znaków i skrótów................ 65

Alfieri............... 67

Saul................ 77

Uwagi nad Saulem............. 135

Aparat krytyczny.............. 141 